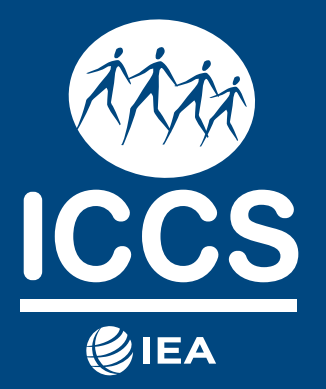

\title{
Young People's Perceptions of Europe in a Time of Change
}

\section{IEA International Civic and Citizenship Education Study 2016 European Report}

Bruno Losito Gabriella Agrusti Valeria Damiani Wolfram Schulz

\section{Springer Open}


Young People's Perceptions of Europe in a Time of Change 
Bruno Losito - Gabriella Agrusti

Valeria Damiani • Wolfram Schulz

\section{Young People's Perceptions of Europe in a Time of Change}

IEA International Civic and Citizenship

Education Study 2016

European Report

胞 Springer Open 
Bruno Losito

Laboratorio di Pedagogia Sperimentale Università degli studi Roma Tre Rome, Italy

\section{Valeria Damiani}

Laboratorio di Pedagogia Sperimentale Università degli studi Roma Tre Rome, Italy
Gabriella Agrusti

Laboratorio di Pedagogia Sperimentale

Università degli studi Roma Tre

Università LUMSA

Rome, Italy

Wolfram Schulz

The Australian Council for Educational Research Camberwell, Victoria, Australia

\section{IEA Secretariat}

Keizersgracht 311

1016 EE Amsterdam, the Netherlands

Telephone: +31206253625

Fax: + 31204207136

email: secretariat@iea.nl

Website: www.iea.nl

All rights reserved. No part of the publication may be reproduced, stored in a retrieval system or transmitted in any form or by any means, electronic, electrostatic, magnetic tape, mechanical, photocopying, recoding, or otherwise without permission in writing from the copyright holder

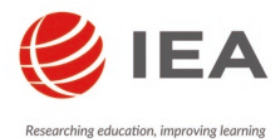

The International Association for the Evaluation of Educational Achievement (IEA), with headquarters in Amsterdam, is an independent, international cooperative of national research institutions and governmental research agencies. It conducts largescale comparative studies of educational achievement and other aspects of education, with the aim of gaining in-depth understanding of the effects of policies and practices within and across systems of education.

Copyedited by Paula Wagemaker Editorial Services, Oturehua, Central Otago, New Zealand Design by Becky Bliss Design and Production, Wellington, New Zealand

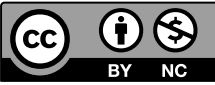

ISBN 978-3-319-73959-5 ISBN 978-3-319-73960-1 (eBook)
https://doi.org/10.1007/978-3-319-73960-1

Library of Congress Control Number: 2017964509

(c) International Association for the Evaluation of Educational Achievement (IEA) 2018. This book is an open access publication.

Open Access This book is licensed under the terms of the Creative Commons Attribution-NonCommercial 4.0 International License (http://creativecommons.org/licenses/by-nc/4.0/), which permits any noncommercial use, sharing, adaptation, distribution and reproduction in any medium or format, as long as you give appropriate credit to the original author(s) and the source, provide a link to the Creative Commons license and indicate if changes were made. The images or other third party material in this book are included in the book's Creative Commons license, unless indicated otherwise in a credit line to the material. If material is not included in the book's Creative Commons license and your intended use is not permitted by statutory regulation or exceeds the permitted use, you will need to obtain permission directly from the copyright holder.

This work is subject to copyright. All commercial rights are reserved by the author(s), whether the whole or part of the material is concerned, specifically the rights of translation, reprinting, reuse of illustrations, recitation, broadcasting, reproduction on microfilms or in any other physical way, and transmission or information storage and retrieval, electronic adaptation, computer software, or by similar or dissimilar methodology now known or hereafter developed. Regarding these commercial rights a non-exclusive license has been granted to the publisher.

The use of general descriptive names, registered names, trademarks, service marks, etc. in this publication does not imply, even in the absence of a specific statement, that such names are exempt from the relevant protective laws and regulations and therefore free for general use.

The publisher, the authors and the editors are safe to assume that the advice and information in this book are believed to be true and accurate at the date of publication. Neither the publisher nor the authors or the editors give a warranty, express or implied, with respect to the material contained herein or for any errors or omissions that may have been made. The publisher remains neutral with regard to jurisdictional claims in published maps and institutional affiliations.

Printed on acid-free paper

This Springer imprint is published by the registered company Springer International Publishing AG part of Springer Nature.

The registered company address is: Gewerbestrasse 11, 6330 Cham, Switzerland 


\section{Foreword}

High-quality, large-scale comparative studies of education systems across the world enable better understanding of the policies and practices that foster educational progress. They also play a critical role in helping nations build their own knowledge and research capacity. For over 60 years, the International Association for the Evaluation of Educational Achievement (IEA) has conducted such research studies, with the aim of improving learning for all.

Educational research should focus on more than students' ability in relation to foundational skills such as mathematics, science, and literacy. Civic and citizenship education has an equally important role in preparing our children for life after school. The International Civic and Citizenship Education Study (ICCS) and its predecessors demonstrate the IEA's ongoing commitment to research focused on the holistic goals of education.

Viewed from a global perspective, the release of the results from this second cycle of ICCS could not be timelier. ICCS 2016 is the fourth IEA study to investigate the ways in which education systems prepare young people to undertake their current and future roles as citizens. The study recognizes that foundational skills are important, but that these alone are not sufficient to help young people truly prosper in a world that requires an open and culture-oriented approach, a moral orientation emphasizing human rights, and a focus on social justice and active political participation. ICCS 2016 provides data, evidence, and research on students' knowledge and understanding of civics and citizenship in 24 countries. It also includes measures of persisting aspects of civic and citizenship, examines differences among and within countries, and provides statistical links that ensure a sound basis for comparing the findings of ICCS 2009 and ICCS 2016.

As in 2009, ICCS 2016 offered the participating countries the option of supplementing the comprehensive core assessment with two regional student questionnaire components, one for countries in Europe and the other for countries in Latin America. The questionnaires were designed to measure civic and citizenship education-related aspects of specific relevance to each of these geographic regions. In the case of the present European report, these aspects included European identity, recent European political and social events, such as immigration from outside Europe and freedom of movement within European borders, and European economic conditions and foreign policy. From my perspective, these aspects are fundamentally linked to developing students' citizenship competencies and establishing students' roles as citizens in a changing world. This European report is self-standing, but the additional topics and findings are a useful and focused supplement to the international survey and report. I therefore recommend that readers consult the ICCS 2016 international report for a comprehensive critical analysis of the study's findings.

The report for the Latin American region will follow in early 2018, as will a technical report, an international public-use database, and an accompanying user guide, designed to enable the research community to make best use of the data for their own in-depth analyses.

In collaboration with the education systems participating in ICCS, the IEA established two central aims for ICCS in order to improve countries' understanding of these issues. The first aim focuses on monitoring changes in students' civic knowledge, attitudes, and engagement over time; the second on addressing new and emerging civic-related challenges. I am convinced that the reliable and comparable evidence and data provided by ICCS will enable countries to evaluate the strengths of their educational policies and to measure progress toward achieving national, regional, and international goals. ICCS 2016 provides many positive signals and insights which, in combination, indicate that students of the early 21st century have a growing civic knowledge and respect for social diversity. Nevertheless, the study findings also reveal substantial levels of variation among students with respect to the study's findings, with this variation often more evident within than between countries. 
Building on the success of the 2009 and 2016 studies, the IEA will conduct the next cycle of ICCS in 2022, recognizing once again that studying civic and citizenship education is a 'moving target' which needs to respond to changes in national, regional, and international contexts. Recently, global citizenship education (GCED) and education for sustainable development (ESD) were identified as critical components of the international education agenda, expressed as part of Target 4.7 of the United Nations Sustainable Development Goals (SDGs). At the same time, European institutions and agencies are developing or updating civic and citizenship competence frameworks, policy advice, and curricular guidance, along with related measurement strategies. The IEA expects that a regional addition for Europe will be developed again for ICCS 2022, and that its development and implementation will take place in cooperation with both the participating countries and in consultation with European organizations such as the European Commission and the Council of Europe.

For ICCS 2016, the IEA drew on its established international network of research organizations, scholars, and technical experts. Two partner organizations, in cooperation with the IEA and the study's national research coordinators (NRCs), organized and implemented the study: the Australian Council for Educational Research (ACER), and the Laboratorio di Pedagogia Sperimentale (LPS) at the Roma Tre University in Italy, the lead organization responsible for this report. I would like to express my sincere gratitude to the research teams for the passion, intellect, and dedication that made this report a reality, namely, Gabriella Agrusti, Valeria Damiani, and Bruno Losito from LPS, and Wolfram Schulz from ACER. Extended thanks go to the larger ICCS research team for their analytical work, critical review, and overall support during the drafting stage: John Ainley, Julian Fraillon, Tim Friedman, and Eveline Gebhardt from ACER.

My special thanks go to the members of the study's Project Advisory Committee (PAC) for their thoughtful and scholarly guidance during the study's development and reporting: specifically, Erik Amnå (Örebro University, Sweden), Cristián Cox (University Diego Portales, Chile), Barbara MalakMinkiewicz (IEA honorary member, the Netherlands), Judith Torney-Purta (University of Maryland, the United States), and Wiel Veugelers (University of Humanistic Studies, the Netherlands). I am also grateful for the expert advice provided by the ICCS 2016 sampling referee, Marc Joncas, and Christian Monseur (University of Liège, Belgium), who undertook a technical review of scaling and reporting procedures.

My sincere thanks are also due to the key research, operations, and management staff at the IEAFalk Brese, Roel Burgers, Christine Busch, Ralph Carstens, Juliane Kobelt, Paulína Koršňáková, Marta Kostek, Hannah Köhler, Andrea Netten, Gabriela Noveanu, and Sabine Weber-for their tireless leadership and commitment to the success of the project. The IEA Publications and Editorial Committee (PEC) provided critical feedback and suggested improvements to earlier versions of this report. I thank Seamus Hegarty on behalf of the group, as well as Paula Wagemaker and Gillian Wilson for editing this report and managing its timely production.

As is the case with all IEA studies, ICCS 2016 has depended on the critical engagement, perseverance, and enthusiasm of the national research coordinators and their teams from the 15 education systems who participated in the European option and contributed to this report. From collaboration on the scoping and development of the European questionnaire component, through careful management and execution of the study at the national level, to guidance on this publication, these individuals and their sustained contributions have ensured a truly successful venture. They are both the foundation and our guides in all of the IEA's endeavors.

Core funding for the international and regional studies was provided by the 24 countries and education systems that participated in ICCS 2016. I would like to thank the European Commission Directorate-General for Education and Culture for providing grant support to the European countries participating in the study and, in particular, to this European component. 
Finally, all of us owe our deepest gratitude to the many thousands of students, teachers, and school principals involved for their willingness, time, and efforts in providing the information that underpins this European report. Without them, this study would not have been possible. We look forward to the many publications, research papers, and conference contributions inspired by the data from this important study.

Dirk Hastedt

EXECUTIVE DIRECTOR, IEA 


\section{Contents}

Foreword $\quad v$

List of tables and figures $\quad x$

Executive summary xiii

About the study xiii

Keyfindings xiii

Implications of findings $\quad$ XV

Chapter 1: General overview 1

Previous findings from the ICCS 2009 European regional survey 3

Content and structure of the ICCS 2016 European regional questionnaire and report 4

References 5

Chapter 2: Students' perceptions of their being european and students' opportunities 7 to learn about Europe at school

$\begin{array}{ll}\text { Chapter highlights and summary } & 7\end{array}$

Students' perceptions of European identity 8

Students' opportunities to learn about Europe at school 13

References 16

Chapter 3: Students' attitudes toward freedom of movement and immigration 19

in Europe

Chapter highlights and summary 19

Students' attitudes toward freedom and restriction of movement for European $\quad 20$

citizens within Europe

Students' attitudes toward immigration $\quad 24$

References $\quad 30$

Chapter 4: Students' perceptions of Europe and the future of Europe 33

Chapter highlights and summary 33

Students' attitudes toward cooperation among European countries 34

Students' perceptions of Europe's future 38

Students' perceptions of the European Union $\quad 41$

Students' perceptions of their life in the future $\quad 44$

$\begin{array}{ll}\text { References } & 47\end{array}$

Chapter 5: Main findings and implications for policy and practice 49

Summary of main findings $\quad 49$

Implications for policy and practice $\quad 51$

Outlook $\quad 52$

References $\quad 52$

Appendices $\quad 53$

Appendix A: Sampling information and participation rates 53

Appendix B: Student percentages for dichotomous variables $\quad 55$

Appendix C: Item maps 56

Appendix D: Organizations and individuals involved in ICCS 2016 


\section{List of tables and figures}

Table 1.1: Numbers of surveyed students with data from the European regional 2 questionnaire

Table 2.1: $\quad$ Students' perceptions of their European identity 10

Table 2.2: National averages of students' sense of European identity 11

Table 2.3: National average scale scores indicating students' sense of European identity 12 by gender, immigrant background, and students' trust in civic institutions

Table 2.4: Students' reports on their opportunities for learning about Europe at school 15

Table 3.1: Students' attitudes toward freedom and restriction of movement within 22 Europe

Table 3.2: National average scale scores indicating students' attitudes toward freedom of movement within Europe by gender, immigrant background, and level of civic knowledge

Table 3.3: National average scale scores indicating students' attitudes toward restriction of movement within Europe by gender, immigrant background, and level of civic knowledge

Table 3.4: Students' attitudes toward equal rights for immigrants 27

Table 3.5: National averages of students' endorsement of equal rights for immigrants 28

Table 3.6: National average scale scores indicating students' attitudes toward equal 29 rights for immigrants by gender, immigrant background, and level of civic knowledge

Table 4.1: Students' attitudes toward cooperation among European countries 36

Table 4.2: National average scale scores indicating students' views on cooperation among European countries by gender, immigrant background, and level of civic knowledge

Table 4.3: Students' positive expectations regarding the future of Europe 39

Table 4.4: Students' negative expectations regarding the future of Europe 40

Table 4.5: Students' attitudes toward the European Union 42

Table 4.6: Students' trust in European institutions 43

Table 4.7: Students' expected electoral participation 45

Table 4.8: Students' expectations for their individual future 46

Table A.1: Coverage of ICCS 2016 target population 53

Table A.2: Participation rates and sample sizes for student survey 54

Table B.1: Percentages of students in categories for dichotomous variables 55

\section{Figures}

Figure 1.1: Countries that administered the European ICCS 2016 student 2 questionnaire

Figure C.1: Example of questionnaire item map 57

Figure 2.1: Item map for the scale reflecting students' sense of European identity 58

Figure 2.2: Item map for the scale reflecting students' reports on opportunities for $\quad 59$ learning about Europe at school 
Figure 3.1: Item map for the scale reflecting students' attitudes toward freedom of migration within Europe

Figure 3.2: Item map for the scale reflecting students' attitudes toward restricting migration within Europe

Figure 3.3: Item map for the scale reflecting students' attitudes toward equal rights for immigrants

Figure 4.1: Item map for the scale reflecting students' attitudes toward cooperation among European countries

Figure 4.2: Item map for the scale reflecting students' positive expectations for European future

Figure 4.3: Item map for the scale reflecting students' negative expectations for European future

Figure 4.4: Item map for the scale reflecting students' attitudes toward European Union

Figure 4.5: Item map for the scale reflecting students' expectations for their individual future 


\title{
Executive summary
}

\begin{abstract}
About the study
The International Civic and Citizenship Education Study (ICCS) investigates the ways in which young people are prepared to undertake their roles as citizens in a range of countries. ICCS 2016, a continuation and extension of ICCS 2009, was developed in response to persistent and newly emerging challenges of educating young people in a world where contexts of democracy and civic participation continue to change.

In recent years, various political and social issues in Europe have raised concerns about the future co-operation and integration of European countries. The European student questionnaire aimed to assess aspects of civic and citizenship education related to the European context and to the European social and political situation that participating countries in this region consider of specific importance and relevance.
\end{abstract}

The questionnaire also sought to gather information that would allow exploration of students' attitudes toward the most pressing issues presently confronting Europe (e.g., migration from outside Europe to Europe, freedom of movement across the European borders, the financial crisis) and of students' sense of European identity. In addition to this, the European student questionnaire gathered data on aspects of students' attitudes that were also collected during the 2009 ICCS survey. Inclusion of these aspects made it possible to compare results across the two ICCS cycles.

Although the general purpose of the European student questionnaire was to investigate Europespecific civic and citizenship issues, all measures were developed in reference to the overarching ICCS 2016 assessment framework. The data collected with this instrument should be regarded as supplementing the international survey results by providing further information specific to the region. In addition, aspects measured in relation to the European regional context encompass aspects specifically related to European integration and to policies and practices particular to the European Union (EU).

The European student questionnaire in ICCS 2016 gathered data from almost 53,000 students in their eighth year of schooling in 14 European countries and one benchmarking participant (the German state of North Rhine-Westphalia).

\section{Key findings}

\section{Students' perceptions of their being European}

As in ICCS 2009, the European ICCS 2016 questionnaire included a question asking students about their agreement or disagreement with a series of statements on European identity and belonging.

Across participating countries, majorities of surveyed students stated that they saw themselves as Europeans, that they were proud to live in Europe, and that they felt they were part of Europe, results which, as in ICCS 2009, indicate a strong sense of European identity and belonging. In comparison to ICCS 2009, we observed considerable increases in students' positive perceptions of their European identity in almost all of the countries that participated in both surveys.

Majorities of students from non-immigrant families and students reporting a high level of trust in civic institutions tended to express an even stronger sense of European identity. In most countries, we recorded a slightly stronger sense of European identity among male students than among females (as previously observed in ICCS 2009). 


\section{Students' opportunities to learn about Europe at school}

Majorities of students said they had opportunities to learn about Europe at school. On average across the participating countries, 83 percent of the surveyed students reported that they had opportunities to learn at their schools about the history of Europe. Opportunities to learn about political and economic systems at European level, about political and social issues in European countries, and about political and economic integration between European countries varied to a greater extent across the participating European countries.

\section{Students' attitudes toward freedom of movement within Europe and toward equal rights for immigrants in Europe}

Most of the surveyed students endorsed freedom of movement for European citizens within Europe. Across participating countries, large majorities of students strongly agreed or agreed with statements regarding freedom of movement for European citizens within Europe and tended to strongly disagree or to disagree with statements regarding restriction of movement. However, we also observed considerable variation across countries for statements endorsing restricting European citizens' freedom of movement.

Lower-secondary students with a higher level of civic knowledge (at or above Level B on the civic knowledge scale) were more in favor of freedom of movement than those students with a lower level of civic knowledge (below Level B). Male students were more in favor than female students of restricting European citizens' freedom of movement.

The European student questionnaire in ICCS 2016 measured students' endorsement of the principle of providing equal rights and opportunities to immigrants. The inclusion of this question in the ICCS 2009 student questionnaire allowed us to compare the results between 2009 and 2016 for the European countries that participated in both surveys. On average, majorities of students agreed with statements endorsing immigrants' rights, although we also found evidence of differences across the European ICCS 2016 countries. Most countries recorded no strong difference between their ICCS 2009 students' and their ICCS 2016 students' attitudes toward equal rights for immigrants. In all countries, female students held more positive attitudes toward immigrants' rights than males did. Students' endorsement of equal rights for immigrants was positively associated with higher levels of civic knowledge (at or above Level B). In most countries, students from immigrant families expressed more positive attitudes than the other students did toward immigrant rights.

\section{Students' perceptions of Europe and the future of Europe}

Nearly all surveyed students favored cooperation among European countries in order to ensure high levels of employment, strengthen countries' economies, prevent and combat terrorism, and protect the environment. Students' support for cooperation among European countries was positively associated with higher levels of civic knowledge.

Majorities of students expressed positive expectations with respect to Europe's future, especially in relation to an increase in cooperation among European countries and the strengthening of peace and democracy across Europe. However, students perceived some issues (such as pollution) as more concerning for the future of Europe. Students regarded terrorism as one of the most problematic issues.

In most of the participating countries, majorities of students were positive about their own individual future. However, we observed slightly lower percentages and also more variation across countries with respect to students' expectations of their future financial situation. 
Most students held positive views of the EU and tended to endorse statements about the importance of the $E U$ in guaranteeing respect for human rights, safety in Europe, protecting the environment, strengthening the economy, and sharing a set of common rules and laws.

Most of the surveyed students also expressed trust in the European Commission and the European Parliament. Students' expectations of voting in European elections in the future varied substantially across participating countries.

\section{Implications of findings}

Any discussion of potential implications for policy and practice requires careful consideration of the limitations associated with the cross-sectional design of ICCS 2016, and also with the selfreported results from the European student questionnaire. However, the European ICCS 2016 data show a number of interesting results that suggest possible policy implications for the future.

The first such finding is the association between students' perceptions of their European identity and their trust in civic institutions. The more students trusted their national civic institutions, the more likely they were to see themselves as part of a broader community at the supranational level. These findings suggest that national and European identities can positively coexist and do not contradict each other.

The findings regarding students' opportunities to learn about civics and citizenship at school showed variation across countries. These findings not only support the results of previous studies on the national curricula of European countries, but also indicate that there is potential for schools to enhance students' learning of European topics and issues.

Despite the variation observed across countries, students with higher levels of civic knowledge tended to be the students expressing more tolerant attitudes. They were also more in favor than their less knowledgeable peers of cooperation among European countries. These results suggest that, through improved civic learning, schools have the potential to strengthen students' civic knowledge and to facilitate more open and tolerant views.

Findings from the ICCS 2016 European student survey showed that the national percentages of students who said they would certainly or probably vote in European elections were lower than those of students who said they would certainly or probably vote in national and local elections. ICCS 2016 results also showed an association between students' expectation to vote and their level of civic knowledge. These findings suggest that including EU-related topics in national curricula and developing initiatives designed to support students' engagement at school and in their communities may strengthen students' awareness of the importance of their participation as citizens at a supranational level. 


\section{CHAPTER 1:}

\section{General overview}

The International Civic and Citizenship Education Study (ICCS) investigates the ways in which young people are prepared to undertake their roles as citizens in a range of countries. ICCS 2016, a continuation of the study initiated in 2009, served as a response to the emerging challenges of educating young people in a world where contexts of democracy and civic participation continue to change (Schulz, Ainley, Fraillon, Losito, \& Agrusti, 2016). ICCS 2016 reported on student achievement using a test of conceptual knowledge and understanding of aspects of civics and citizenship. The study accordingly collected and analyzed data on students' values, beliefs, attitudes, behaviors, and behavioral intentions related to civics and citizenship.

The European student questionnaire aimed to assess aspects of civic and citizenship education that have relevance to the European context and to the social and political situations that countries in this region consider have region-specific importance. Various political and social events over recent years have raised concerns about the future viability of cooperation and integration across European countries. Among the most pressing issues confronting Europe in 2016/2017 were those linked to migration and refugees, the economy (unemployment, public finances, inflation), and foreign and security policy (World Economic Forum, 2016).

The European student questionnaire consequently sought to gather information that would allow exploration of students' attitudes toward these processes, and of students' sense of European identity. The questionnaire also contained questions enabling investigation of issues such as migration from outside Europe to Europe, and freedom of movement across European borders. We recommend that this report be read in conjunction with the international report on ICCS 2016 (Schulz, Ainley, Fraillon, Losito, Agrusti, \& Friedman, 2018) and with reference to the ICCS 2016 assessment framework (Schulz et al., 2016).

Although the 2016 European student questionnaire included items pertaining to new regionspecific issues of civic and citizenship education (e.g., migration within Europe, the financial crisis, European cooperation to address common issues), it also gathered data on aspects of students' attitudes that were collected during the 2009 ICCS survey. This inclusion made it possible to compare data across the two ICCS cycles.

In the European region, 14 countries $^{1}$ and one benchmarking participant (the German state of North Rhine-Westphalia) participated in ICCS 2016 and administered the European student questionnaire (see Figure 1.1). This report focuses on the data gathered by that questionnaire from random samples of students (52,788 in total; see Table 1.1) typically in their eighth year of schooling. ${ }^{2}$

\footnotetext{
1 For ICCS 2016, the word "countries" also refers to sub-regions or education systems that participated in the study. The Flemish part of Belgium is an example.

2 Malta assessed Grade 9 students given that the average age of Grade 8 students is below 13.5. In order to assess an age group similar to those in other Nordic countries, Norway deviated (for ICCS 2016) from the International Defined Target population and assessed Grade 9 instead of Grade 8. As a consequence, all Norwegian results are presented with an annotation. Because Norway included Grade 9 as an additional population in ICCS 2009, it is still possible to compare results for this country between 2009 and 2016 for the chosen target population.
} 
Figure 1.1: Countries that administered the European ICCS 2016 student questionnaire

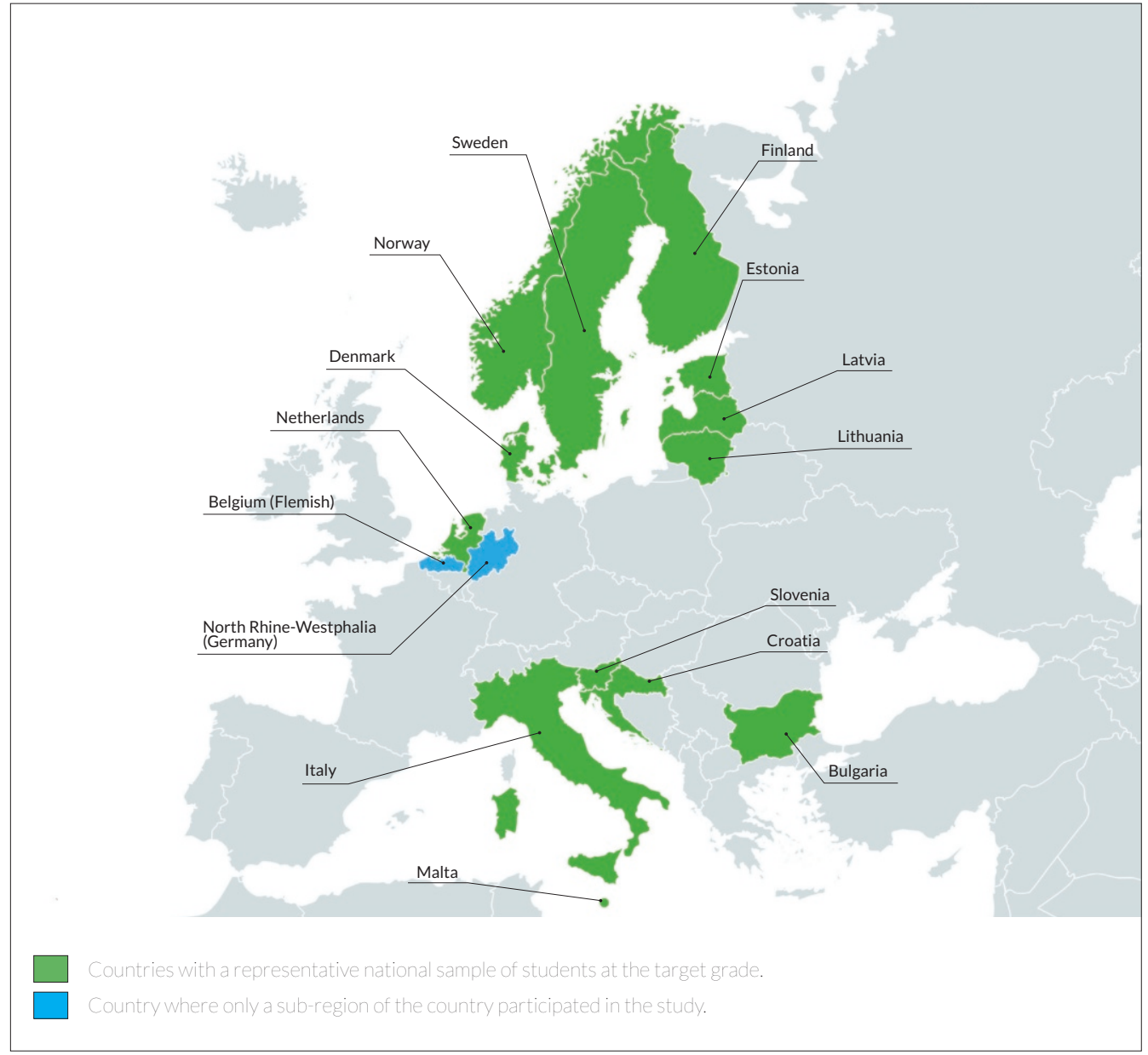

Table 1.1: Numbers of surveyed students with data from the European regional questionnaire 3

\begin{tabular}{l|c}
\hline Country & Number of surveyed students \\
\hline Belgium (Flemish) & 2931 \\
\hline Bulgaria & 2966 \\
\hline Croatia & 3896 \\
\hline Denmark & 6254 \\
\hline Estonia & 2857 \\
\hline Finland & 3173 \\
\hline Italy & 3450 \\
\hline Latvia & 3224 \\
\hline Lithuania & 3631 \\
\hline Malta & 3764 \\
\hline Netherlands & 2812 \\
\hline North Rhine-Westphalia (Germany) & 1451 \\
\hline Norway & 6271 \\
\hline Slovenia & 2844 \\
\hline Sweden & 3264 \\
\hline Total & 52,788 \\
\hline
\end{tabular}

3 The sampling design is described in the ICCS 2016 technical report (Schulz, Carstens, Losito, \& Fraillon, forthcoming). 
As stated above, the general purpose of the European student questionnaire was to investigate Europe-specific civic and citizenship issues. However, all measured constructs can be mapped to the overarching ICCS 2016 assessment framework (Schulz et al., 2016), and the data collected should be regarded as supplementing the international survey results in terms of providing further information specific to the region. Please note also that aspects measured in relation to the European regional context in general include questions more specifically related to European integration and to policies and practices particular to the European Union (EU).

Development of the European regional student questionnaire was undertaken alongside and with reference to the development of other ICCS 2016 instruments. The process commenced with a revision of the previous ICCS 2009 European instrument. This work was carried out in close cooperation with the participating countries, and it led to the identification of new issues of interest that could be mapped to the ICCS 2016 assessment framework. Throughout the different development stages, European national research coordinators (NRCs) reviewed draft questionnaire items. Their suggestions and proposals were discussed during NRC meetings and during a dedicated meeting of the European NRCs. Input and feedback from countries were integral to the successful development of the European student questionnaire.

\section{Previous findings from the ICCS 2009 European regional survey}

ICCS 2009 developed three regional instruments-for Asia, Europe, and Latin America (Fraillon, Schulz, \& Ainley, 2012; Kerr, Schulz, \& Fraillon, 2011; Kerr, Sturman, Schulz, \& Burge, 2010; Schulz, Ainley, Friedman, \& Lietz, 2011). Twenty-four of the 26 European countries that participated in ICCS 2009 administered the European regional instrument, which consisted of two parts. The first part was a test designed to measure students' knowledge about the EU and its policies and institutions, as well as of basic facts about the EU, its laws, and the euro currency. The second part was a questionnaire designed to gather data on the following: students' perceptions of European identity; students' engagement in activities related to Europe; students' attitudes toward learning European languages, migration within Europe, and European integration; and students' selfreported knowledge about the EU.

Although a majority of European students surveyed in ICCS 2009 demonstrated knowledge of main civic and citizenship institutions and understanding of the interconnectedness of institutions and processes, substantial minorities of students had relatively low levels of civic knowledge. Considerable variation in students' knowledge about the EU and its laws and policies was also evident.

The results furthermore showed marked variation in students' attitudes toward European civic issues. A majority of students indicated positive attitudes toward intercultural relations and European language learning. They also stated strong support for equal rights for minority groups, for immigrants, and for freedom of movement of citizens within Europe. However, large minorities of students expressed rather negative attitudes toward the above-mentioned areas (Kerr, Sturman, Schulz, \& Burge, 2010). 


\section{Content and structure of the ICCS 2016 European regional questionnaire and report}

The ICCS 2016 European regional instrument consisted of a questionnaire primarily focused on affective and behavioral domains. It included 11 questions (with Likert-type response categories) aimed at investigating students' interest in and opinions regarding the following Europe-specific civics and citizenship issues: ${ }^{4}$

- Students' perceptions of their European identity. This question was included in ICCS 2009, and the items relating it were not modified for ICCS 2016.

- Students' reports on opportunities to learn about Europe at school. A similar question was included in ICCS 2009 but was modified for ICCS 2016.

- Students' views on European citizens' freedom to reside and work within Europe. This question was included in ICCS 2009 but was modified for inclusion in ICCS 2016.

- Students' attitudes toward immigration. This question was included in the ICCS 2009 (international) student questionnaire, and the same items were used for the 2016 European questionnaire.

- Students' views on cooperation among European countries. This question was a new one for ICCS 2016.

- Students' perceptions of discrimination in Europe (a new question for ICCS 2016).

- Students' perceptions of the future of Europe (new question for ICCS 2016).

- Students' perceptions of their life in the future (new question for ICCS 2016).

- Students' attitudes toward political and ethical consumerism (new question for ICCS 2016).

- Students' views on the age at which young people should acquire different rights and obligations (a new question for ICCS 2016).

- Students' perceptions of the European Union (a new question for ICCS 2016).

This report does not present findings from all questions in the European student questionnaire. Rather, it focuses on students' attitudes and perceptions toward three civic and citizenship content areas related to the European context:

- Students' perceptions of their being European and students' opportunities to learn about Europe at school;

- Students' attitudes toward freedom and restriction of movement and immigration in Europe; and

- Students' perceptions of Europe and the future of Europe.

The results presented in this report also do not include findings based on the international instruments. However, some data regarding topics that are relevant to the European regional context are included (specifically, data related to European options forming part of the student questionnaire).

This report has five chapters. Chapter 2 examines students' sense of European identity and the opportunities students have to learn about Europe at school. Chapter 3 focuses on students' attitudes toward freedom and restriction of movement for European citizens within Europe and

4 The metric of the European regional questionnaire, as in all ICCS 2016 questionnaire scales, was set to a mean of 50 and a standard deviation of 10 for equally weighted national samples that had met sample participation requirements. For two scales (measuring students' sense of European identity and endorsement of equal rights and opportunities for immigrants), the scores were set to the same metric as in ICCS 2009, so that in these cases 50 reflects the ICCS 2009 average (with equally weighted national samples) and 10 the corresponding standard deviation. 
toward the principle of providing equal rights and opportunities to immigrants. Chapter 4 reports on students' perceptions of the future of Europe and of their individual futures. It also covers students' perceptions of the EU. In the final chapter, Chapter 5, we discuss possible implications of the main findings for policy and practice.

\section{References}

Fraillon, J., Schulz, W., \& Ainley, J. (2012). ICCS 2009 Asian report: Civic knowledge and attitudes among lower secondary students in five Asian countries. Amsterdam, the Netherlands: International Association for the Evaluation of Educational Achievement (IEA).

Kerr, D., Schulz, W., \& Fraillon, J. (2011). The development of regional instruments. In W. Schulz, J. Ainley, \& J. Fraillon (Eds.), ICCS 2009 technical report (pp. 45-49). Amsterdam, the Netherlands: International Association for the Evaluation of Educational Achievement (IEA).

Kerr, D., Sturman, L., Schulz, W., \& Burge, B. (2010). ICCS 2009 European report: Civic knowledge, attitudes and engagement among lower secondary school students in twenty-four European countries. Amsterdam, the Netherlands: International Association for the Evaluation of Educational Achievement (IEA).

Schulz, W., Ainley, J., Fraillon, J., Losito, B., \& Agrusti, G. (2016). IEA International Civic and Citizenship Education Study 2016: Assessment framework. Cham, Switzerland: Springer.

Schulz, W., Ainley, J., Fraillon, J., Losito, B., Agrusti, G., \& Friedman, T. (2018). Becoming citizens in a changing world: IEA International Civic and Citizenship Education Study 2016 international report. Cham, Switzerland: Springer.

Schulz, W., Ainley, J., Friedman, T., \& Lietz, P. (2011). ICCS 2009 Latin American report: Civic knowledge and attitudes among lower secondary students in six Latin American countries. Amsterdam, the Netherlands: International Association for the Evaluation of Educational Achievement (IEA).

Schulz, W., Carstens, R., Losito, B., \& Fraillon, J. (Eds.) (forthcoming). ICCS 2016 technical report. Amsterdam, the Netherlands: International Association for the Evaluation of Educational Achievement (IEA).

World Economic Forum. (2016, February). Europe: What to watch out for in 2016-2017 (Global Agenda Council on Europe, REF 080116). Geneva, Switzerland: Author. Retrieved from http://www3.weforum. org/docs/GAC16_Europe_What_Watch_Out_for_2016-2017.pdf

Open Access This chapter is licensed under the terms of the Creative Commons Attribution-NonCommercial 4.0 International License (http://creativecommons.org/licenses/by-nc/4.0/), which permits any noncommercial use, sharing, adaptation, distribution and reproduction in any medium or format, as long as you give appropriate credit to the original author(s) and the source, provide a link to the Creative Commons license and indicate if changes were made.

The images or other third party material in this chapter are included in the chapter's Creative Commons license, unless indicated otherwise in a credit line to the material. If material is not included in the chapter's Creative Commons license and your intended use is not permitted by statutory regulation or exceeds the permitted use, you will need to obtain permission directly from the copyright holder. 


\section{CHAPTER 2:}

\section{Students' perceptions of their being European and students' opportunities to learn about Europe at school}

\section{Chapter highlights and summary}

Surveyed students expressed a strong sense of European identity and belonging.

- Across participating countries, majorities of students indicated that they saw themselves as Europeans, were proud to live in Europe, and felt they were part of Europe. (Table 2.1)

- During the period between ICCS 2009 and 2016, students' positive perceptions of their European identity increased in the majority of countries. (Table 2.2)

- In most participating countries, male students tended to express a slightly stronger sense of European identity than female students did. (Table 2.3)

- Majorities of students from an immigrant family held a weaker sense of European identity than did students from a non-immigrant family. (Table 2.3)

- Consistent and statistically significant positive associations were observed between students' sense of European identity and students' level of trust in civic institutions. (Table 2.3)

Majorities of students said they had opportunities to learn about Europe at school.

- Most surveyed students reported having learned about the history of Europe at school. (Table 2.4)

- Opportunities, as reported by students, to learn about political and economic systems at the European level, about political and social issues in European countries, and about political and economic integration between European countries varied across the ICCS 2016 participating countries. (Table 2.4) 
This chapter examines students' sense of their European identity, a construct that reflects the degree to which students identify with the European region and that is related to the affectivebehavioral domain attitudes in the ICCS 2016 assessment framework (Schulz, Ainley, Fraillon, Losito, \& Agrusti, 2016). The chapter also presents findings on students' opportunities to learn about Europe at school.

\section{Students' perceptions of European identity}

European identity and citizenship have been studied extensively over the past decades. Numerous studies have focused on Europeans' perceptions of European identity and the extent to which these people feel they belong to Europe and/or to the European Union (Alnæs, 2013; Bellamy, Castiglione, \& Shaw, 2006; Checkel \& Katzenstein, 2009; Delanty, 1995; Duchesne, 2008; European Commission, 2012; Herrmann \& Brewer, 2004; Karolewski \& Kaina, 2006; Lehning, 2001; Lepsius, 2001; Spannring, Wallace, \& Datler, 2008; Westle \& Segatti, 2016). These studies highlight the different elements that contribute to the construct of "European identity." However, the multifaceted nature of this construct makes it difficult to define European identity unambiguously.

Some researchers have focused their studies on level of identification with the nation and with Europe through the influence of EU policies and symbols, defining, for instance, the civic/political and cultural components of European identity (Bruter, 2004a, 2004b, 2005; Pichler, 2008) and exploring the relationship between European sense of belonging and the EU's foreign policy (Cerutti \& Lucarelli, 2008). Some scholars have also analyzed the various attributes of European identity in Central and Eastern European countries prior to their accession to the EU (Schilde, 2014). Although a number of scholars argue that national and European identities can positively coexist (Castano, 2004; Citrin \& Sides, 2004; Diez Medrano \& Gutierrez, 2001; Risse, 2010), others claim that nationalist convictions represent an obstacle to effective integration (Fligstein, Polyakova, \& Sandholtz, 2012). Several researchers also claim that European identity is characterized by postnational and cosmopolitan thinking (Delanty \& Rumford, 2005).

The Standard Eurobarometer 85 survey of spring 2016 (European Commission, 2016) showed an increase (since autumn 2015) in the extent of identification with EU citizenship. This increase was evident among majorities of respondents in all member states. Of the European countries participating in ICCS 2016, Malta and Finland recorded the highest percentages of respondents seeing themselves as EU citizens. The lowest percentages were recorded in Italy and Bulgaria. The results also revealed younger generations expressing a stronger sense of EU citizenship than older ones (77\% of the respondents 15 to 24 years of age identified themselves as EU citizens compared to $59 \%$ of the respondents 55 years of age or above).

The European ICCS 2009 questionnaire included a question asking students about their agreement or disagreement with a series of statements on European identity and belonging. Five items with a four point-Likert response scale ranging from "strongly agree" to "strongly disagree" were used to derive a European identity perception scale (Kerr, Sturman, Schulz, \& Burge, 2010). Large majorities of the 2009 lower-secondary students across the European countries showed a strong sense of European identity, with male students expressing stronger feelings of European identity than females. Students from immigrant families were somewhat less inclined to express a sense of European identity than students from non-immigrant families. ${ }^{2}$

1 The background sections of the chapters in this report contain several references to the Eurobarometer survey results. These references should offer a better understanding of the European contexts and issues related to questions included in the regional instrument and are not intended as comparative data. Please note also that (i) the Eurobarometer surveys taken into consideration refer to year of the administration of the European regional questionnaire, (ii) Eurobarometer surveys are not conducted in Norway; and (iii) the survey respondents are older than the young people in the ICCS 2016 target group.

2 ICCS 2009 used the categories "students with immigrant background" and "students without immigrant background". ICCS 2016 divided students into two categories. "Students from immigrant family" included students who reported all parents as born abroad (regardless of where the student was born). "Students from non-immigrant family" comprised students who reported at least one parent born in the country where the survey was conducted. For details see Chapter 3 of the international report (Schulz, Ainley, Fraillon, Losito, Agrusti, \& Friedman, 2018). 
The ICCS 2016 European regional questionnaire included four items from the European ICCS 2009 questionnaire. The items (with Likert-style response categories of "strongly agree," "agree," "disagree," "strongly disagree") were used to measure students' perceptions of their European identity: (a) "I see myself as European;" (b) "I am proud to live in Europe;" (c) "I feel part of Europe;" and (d) "I see myself first as a citizen of Europe and then as a citizen of the world."

The resulting scale had a satisfactory average reliability (Cronbach's alpha $=0.80$ for the pooled international sample). The higher scores on the scale indicate higher levels of students' sense of European identity (see item map in Figure 2.1, Appendix C).

The question on students' sense of European identity in the ICCS 2016 instrument contained two items (unchanged from ICCS 2009) that were optional for EU member countries. ${ }^{3}$ These items used the following statements to measure students' sense of identification with the European Union: (a) "I feel part of the European Union;" and (b) I am proud that my country is a member of the European Union.

According to the responses to these items (summarized in Table 2.1), majorities of students in all participating countries saw themselves as Europeans (95\% on average across the participating countries), were proud to live in Europe (94\%), and felt part of Europe (87\%). In Latvia, the national percentage of students agreeing or strongly agreeing with the third of these statements was more than 10 percentage points (at 73\%) below the European ICCS 2016 average of 87 percent. On average across the participating countries, about 78 percent of students saw themselves first as citizens of Europe and then as citizens of the world. The highest national percentage for this item was found in Croatia (89\%) and the lowest in Latvia (67\%), where the proportion of students agreeing or strongly agreeing with this statement was 10 points below the European ICCS 2016 average.

The average percentage of students across the European countries who felt that they were part of the EU was also 78 percent. National percentages ranged from 61 percent to 89 percent. The highest percentages for this item were observed in Italy (more than 10 percentage points above the European ICCS 2016 average), and the lowest in Latvia (67\%) and the Netherlands (61\%). Cross-nationally, 90 percent of surveyed students, on average, were proud that their country was a member of the European Union.

The average student in the European countries participating in ICCS 2016 expressed a strong sense of European identity (Table 2.2). Croatia, Finland, Italy, Malta, Norway, and Slovenia recorded average scores significantly above the ICCS 2016 European average. The national average for Latvia was more than three score points below the ICCS 2016 average, however. Between 2009 and 2016, we observed an increase in students' positive perceptions of their European identity in almost all countries participating in both surveys. The European average in ICCS 2016 was more than three score points higher than in 2009, which is equivalent to about a third of a standard deviation. The highest increases in average scores between 2009 and 2016 (four score points or more) were recorded in Denmark, Finland, Lithuania, Malta, and Sweden.

Table 2.3 presents the average scale scores by gender group, immigrant background, and trust in civic institutions. The data for students from an immigrant family 4 includes only the data for those countries that had a sufficiently large sample size for this sub-group (at least 50 cases). The columns show the average scores in each comparison group (e.g., for males and females), while the bar chart in between graphically illustrates the direction of each association: the red bars to the left of the zero line indicate score-point differences where students in the first (left-hand side)

3 Denmark and Norway did not administer these optional items.

4 See footnote 2. 

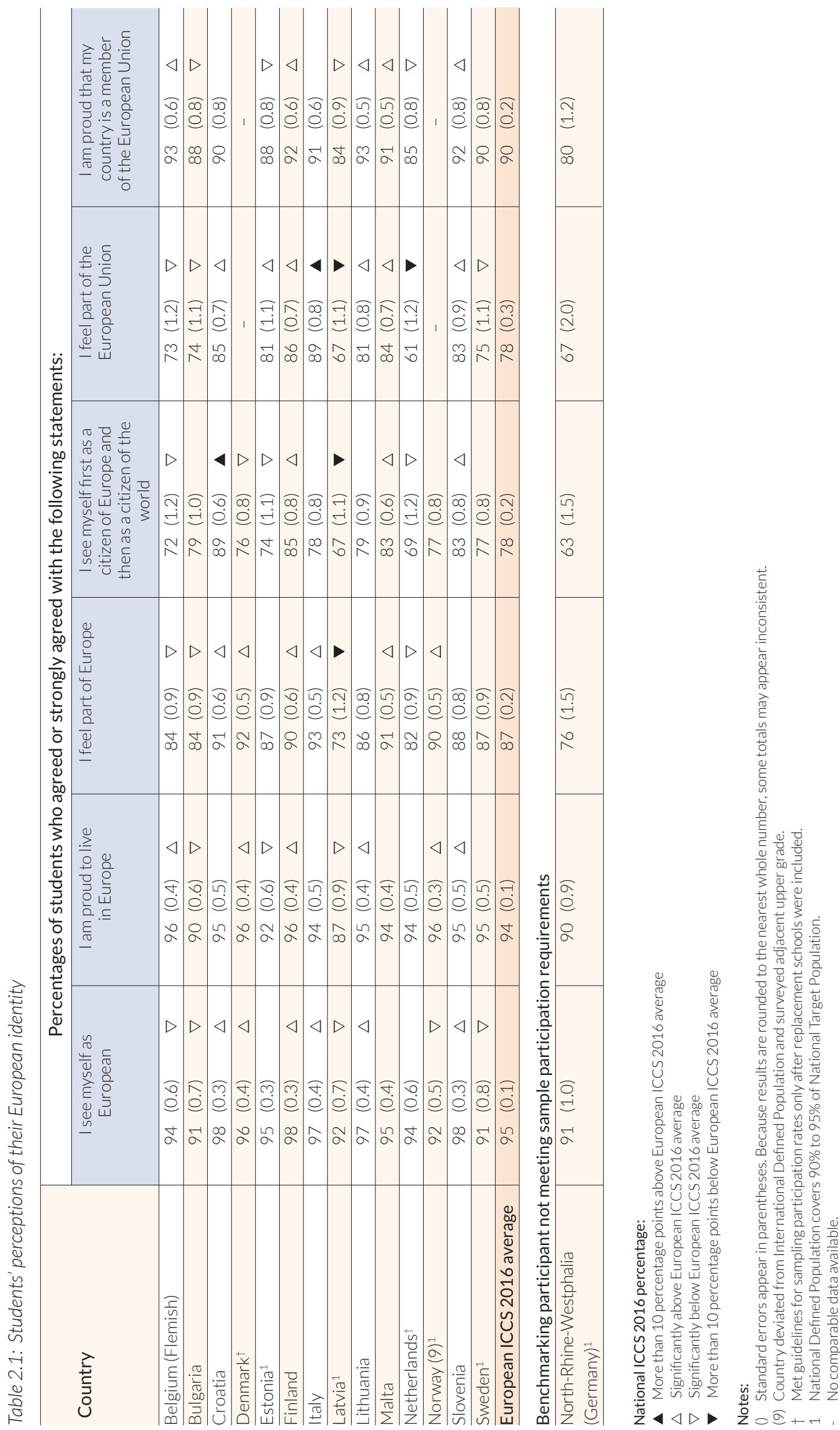
Table 2.2: National averages of students' sense of European identity

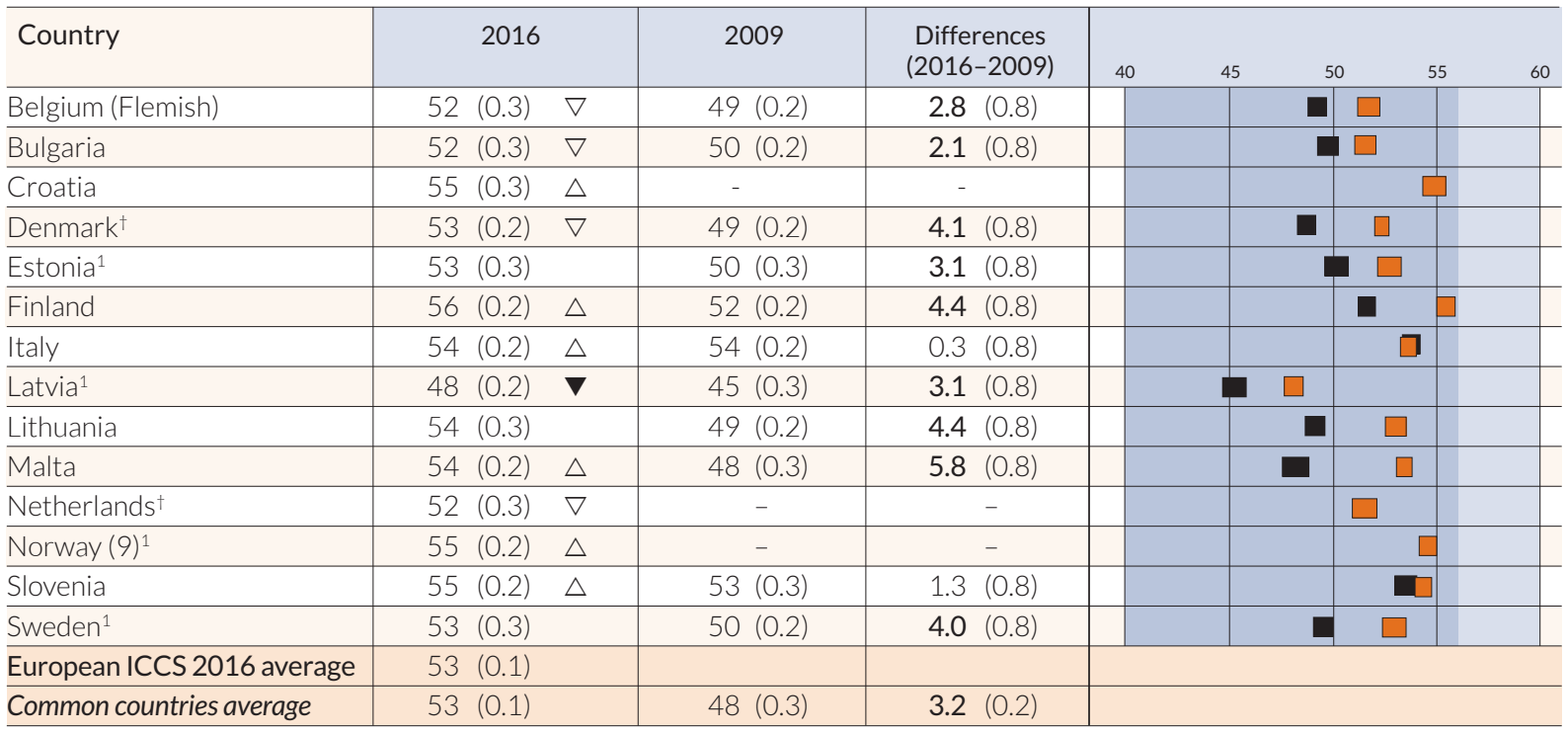

Benchmarking participant not meeting sample participation requirements

\begin{tabular}{l|l|l|l|l|l|l|l|}
\hline $\begin{array}{l}\text { North Rhine-Westphalia } \\
(\text { Germany })^{1}\end{array}$ & $51(0.3)$ & - & - & & & $\square$ \\
\hline
\end{tabular}

2016 average score +/- Confidence interval

2009 average score +/- Confidence interval

\section{National ICCS 2016 average}

- More than 3 score points above European ICCS 2016 average

$\triangle$ Significantly above European ICCS 2016 average

$\nabla$ Significantly below European ICCS 2016 average

$\boldsymbol{\nabla}$ More than 3 score points below European ICCS 2016 average

() Standard errors appear in parentheses.

Statistically significant changes ( $p<0.05$ ) between 2009 and 2016 are displayed in bold.

(9) Country deviated from International Defined Population and surveyed adjacent upper grade.

† Met guidelines for sampling participation rates only after replacement schools were included.

1 National Defined Population covers $90 \%$ to $95 \%$ of National Target Population.

- No comparable data available.

group had significantly $(p<0.05)$ higher values; the green bars indicate score-point differences where the other group had significantly higher averages. ${ }^{5}$

In most countries, male students tended to express a slightly stronger sense of European identity than females (as already observed in ICCS 2009). On average, we recorded a small but statistically significant difference of one score point between males and females. Students from an immigrant family expressed a weaker sense of European identity compared to students from a non-immigrant family. On average, the difference between the two groups was four scale score points. Estonia, Latvia, Lithuania, and the Netherlands recorded the largest differences (seven score points or more). 6

We recorded consistent and statistically significant positive associations between students' sense of European identity and students' trust in civic institutions. On average across the European

5 Results from the benchmarking participant North Rhine-Westphalia (Germany) were not included because North Rhine-Westphalia's very low sample response rates do not permit comparison across sub-groups within the sample.

6 In all participating countries, the socioeconomic status (SES) of students from a non-immigrant family was statistically significantly higher than the socioeconomic status of students from an immigrant family. Latvia was the only country not to register a statistically significant difference between the SES of students from an immigrant family and those from a non-immigrant family. 


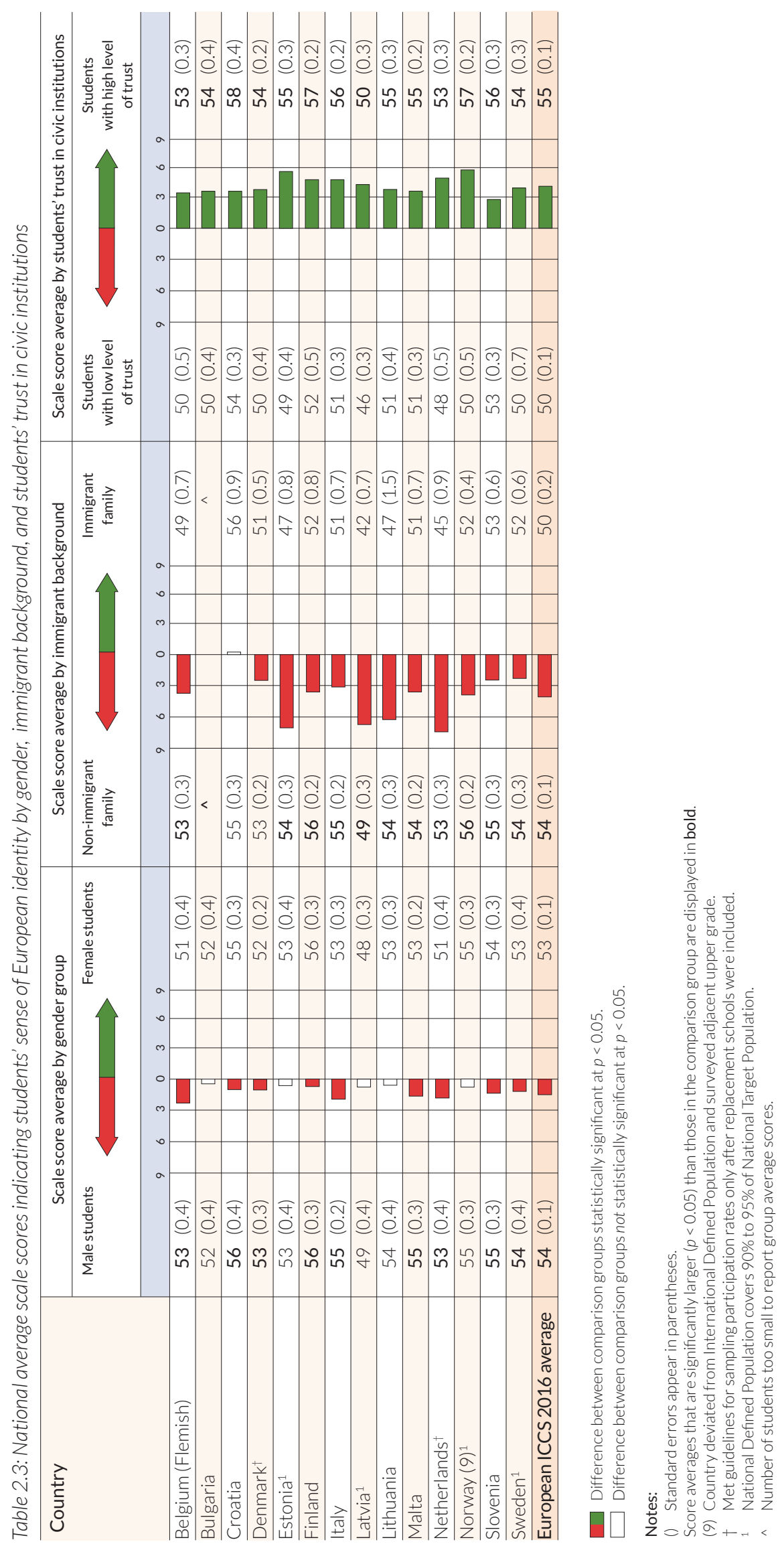


countries, the difference between students reporting a high level of trust and the students reporting a low level of trust was five score points on the European identity scale.?

\section{Students' opportunities to learn about Europe at school}

Most European countries consider civic and citizenship education a relevant area of school education (Eurydice, 2005, 2012; Kerr et al., 2010). At the same time, as evident in several studies, this area of the school curriculum is still characterized by gaps between policies and practices and between intended and implemented curricula (see, for example, Bîrzéa et al., 2004; Veugelers, de Groot, \& Stolk, 2017). Although these studies emphasize the extent of difference across the European countries in how they deliver civic and citizenship education, they identify five approaches overall:

(1) Taught as a separate subject by teachers of subjects related to civic and citizenship education;

(2) Taught by teachers of subjects related to human and social sciences;

(3) Integrated into all subjects taught at school;

(4) Taught as an extracurricular activity; and/or

(5) Considered to be a result of school experience as a whole.

The ICCS 2009 results showed that these five approaches often coexist across the participating European countries (Schulz, Ainley, Fraillon, Kerr, \& Losito, 2010).

Data relating to the aims of civic and citizenship education drawn from the ICCS 2016 national contexts survey revealed a great deal of commonality in civic and citizenship education learning objectives across the European countries. Results from questions in the ICCS 2016 school and teacher questionnaires that asked principals and teachers to select the three most important aims of civic and citizenship education also showed general cross-national agreement that these three aims related to development of students' civic and political knowledge and skills (e.g., promoting knowledge of social, political, and civic institutions; promoting students' critical and independent thinking). The other aims included in the question concerned the development of a sense of responsibility (e.g., promoting the capacity to defend one's own point of view) and the development of active participation (e.g., preparing students for future political engagement). ${ }^{8}$

Having examined the European dimension included in civic and citizenship curricula, the authors of the 2012 Eurydice report (Eurydice, 2012) concluded that this dimension is relevant in the majority of European countries. They also observed that this dimension addresses such matters as European identity and belonging; European history, culture, and literature; the main economic, political, and social issues facing Europe; the functioning of European Union institutions; and European Union perspectives.

According to the Eurydice report, national curricula at the lower secondary level of education (ISCED Level 2) in the majority of the European countries participating in ICCS 2016 cover the themes identified in the report. ${ }^{9}$ Norway and Sweden were the only countries where the issue of European identity and belonging was not a recommended topic in the curriculum. Norway also, along with Malta, did not include content relating to Europe's main economic, political, and social issues. The Norwegian curriculum at lower secondary level, moreover, gave no consideration to issues related to how institutions function; nor did it include European Union perspectives.

7 ICCS 2016 used six items (national government, local government, national parliament, police, courts of justice, political parties) to derive a scale reflecting students' trust in civic institutions (see Chapter 5 of the ICCS 2016 international report; Schulz et al., 2018). Chapter 4 of this current report presents results for students' trust in the European Parliament and in the European Commission (see, in particular, Table 4.6).

8 For more detailed information on the European school contexts, see Chapters 2 and 6 of the international ICCS 2016 report (Schulz et al., 2018).

9 Data for Croatia on citizenship education themes included in national curricula (ISCED 1-3) for school year 2010/2011 were not available in the 2012 Eurydice report. 
The European Union is strongly committed to promoting inclusion of EU topics in the national curricula of its member states (Nicaise \& Blondin, 2003). The EU also carries out initiatives aimed at supporting active citizenship, democracy, tolerance, and human rights. However, as a number of scholars have pointed out, substantial gaps between educational policies and practices still persist (Keating, 2014; Van Driel, Darmody, \& Kerzil, 2016; Veugelers et al., 2017).

The majority of respondents to the Standard Eurobarometer 85 survey (European Commission, 2016) indicated that they knew their rights as European citizens. In Finland, Estonia, Sweden, Lithuania, Denmark, Slovenia, the Netherlands, and Malta, more than half of the respondents said they knew their rights as citizens. The lowest subjective rates of knowledge recorded were those for Croatia, Bulgaria, and Italy.

The ICCS 2016 European regional questionnaire included four items (all modified versions of those used in the European ICCS 2009 questionnaire) designed to capture students' reports on the opportunities they had to learn about topics relevant to Europe at school ("to a large extent," "to a moderate extent," "to a small extent," "not at all"). The four items were (a) "political and economic systems of other European countries;" (b) "the history of Europe;" (c) "political and social issues in other European countries;" and (d) "political and economic integration between European countries (e.g. the European Union)." The four-item scale had a satisfactory average reliability (Cronbach's alpha $=0.77$ for the combined international dataset) (see the item map in Figure 2.2, Appendix C).

The extent to which students said they had opportunities to learn about Europe at school varied substantially across countries (Table 2.4). Four countries, namely Croatia, Finland, Italy, and Lithuania, recorded percentages above the European ICCS 2016 average for all four items.

On average across the participating countries, 83 percent of the surveyed students reported having opportunities to learn about the history of Europe. The highest national percentages were those for Croatia, Estonia, Finland, Italy, Lithuania, and Norway. Only Malta (66\%) had an average percentage more than 10 percentage points below the European ICCS 2016 average.

In Croatia, Finland, Italy, Lithuania, Norway, and Slovenia, more than 70 percent of the students said they had opportunities to learn about the political and economic systems of other European countries. The lowest percentages that we recorded for this item were those for Estonia (52\%) and the Netherlands (53\%).

About 63 percent of students, on average, reported having opportunity to learn about political and social issues in other European countries. The percentages in Estonia, Malta, and the Netherlands were more than 10 points below the European ICCS 2016 average. Higher percentages were found in Croatia, Italy, and Lithuania.

On average, 65 percent of students had, according to them, opportunities to learn about political and economic integration between European countries (e.g., the European Union). The percentages in Estonia, Latvia, and the Netherlands were more than 10 points below the European ICCS 2016 average. Italy and Lithuania recorded the highest percentages.

Table 2.4 also records the national averages for participating countries on the learning about Europe at school scale. Croatia, Italy, and Lithuania recorded the highest scores; Belgium, at more than three points below the European ICCS 2016 average, recorded the lowest score. The scale scores in Bulgaria, Estonia, Latvia, Malta, the Netherlands, and Sweden were significantly below the European ICCS 2016 average. 
Table 2.4: Students' reports on their opportunities for learning about Europe at school

\begin{tabular}{|c|c|c|c|c|c|c|c|c|c|c|}
\hline \multirow{3}{*}{$\begin{array}{l}\text { Country } \\
\text { Belgium (Flemish) }\end{array}$} & \multicolumn{8}{|c|}{$\begin{array}{l}\text { Percentages of students who have had opportunities to learn to a large } \\
\text { or to a moderate extent at school about the following topics: }\end{array}$} & & \\
\hline & \multicolumn{2}{|c|}{$\begin{array}{l}\text { Political and } \\
\text { economic systems } \\
\text { of other } \\
\text { European } \\
\text { countries } \\
\text { (\%) }\end{array}$} & \multicolumn{2}{|c|}{$\begin{array}{l}\text { The history of } \\
\text { Europe } \\
\text { (\%) }\end{array}$} & \multicolumn{2}{|c|}{$\begin{array}{l}\text { Political and } \\
\text { social issues in } \\
\text { other European } \\
\text { countries } \\
(\%)\end{array}$} & \multicolumn{2}{|c|}{$\begin{array}{c}\text { Political and } \\
\text { economic } \\
\text { integration } \\
\text { between European } \\
\text { countries } \\
(\%)\end{array}$} & \multicolumn{2}{|c|}{$\begin{array}{l}\text { Average scale } \\
\text { scores for students' } \\
\text { reporting on } \\
\text { opportunities for } \\
\text { learning about } \\
\text { Europe at school }\end{array}$} \\
\hline & 57 (1.5) & $\nabla$ & $74(1.6)$ & $\nabla$ & $53(1.3)$ & $\nabla$ & $57(1.3)$ & $\nabla$ & $47(0.3)$ & $\nabla$ \\
\hline Bulgaria & $58(1.2)$ & $\nabla$ & 77 (1.0) & $\nabla$ & 58 (1.3) & $\nabla$ & $60(1.3)$ & $\nabla$ & $48(0.3)$ & $\nabla$ \\
\hline Croatia & $71(1.2)$ & $\triangle$ & $92(0.7)$ & $\triangle$ & $73(1.1)$ & $\Delta$ & $74(1.2)$ & $\triangle$ & $53(0.3)$ & $\Delta$ \\
\hline Denmark $^{\dagger}$ & $70(1.0)$ & $\triangle$ & $77(0.8)$ & $\nabla$ & $65(1.0)$ & $\triangle$ & $68(1.0)$ & $\triangle$ & $50(0.2)$ & \\
\hline Estonia $^{1}$ & $52(1.4)$ & $\nabla$ & $89(0.8)$ & $\triangle$ & $51(1.2)$ & $\nabla$ & $50(1.4)$ & $\nabla$ & $48(0.2)$ & $\nabla$ \\
\hline Finland & $71(0.9)$ & $\triangle$ & $92(0.6)$ & $\triangle$ & 67 (1.0) & $\triangle$ & $71(1.0)$ & & $52(0.2)$ & $\triangle$ \\
\hline Italy & $81(0.8)$ & $\Delta$ & $89(0.7)$ & $\triangle$ & $80(0.9)$ & $\Delta$ & $81(0.9)$ & $\Delta$ & $54(0.3)$ & $\Delta$ \\
\hline Latvia $^{1}$ & $59(1.4)$ & $\nabla$ & $82(0.9)$ & & $54(1.1)$ & $\nabla$ & $50(1.1)$ & $\nabla$ & $48(0.3)$ & $\nabla$ \\
\hline Lithuania & $78(1.1)$ & $\Delta$ & $93(0.6)$ & $\Delta$ & 76 (1.1) & $\Delta$ & $83(0.9)$ & $\Delta$ & $55(0.3)$ & $\Delta$ \\
\hline Malta & $59(0.8)$ & $\nabla$ & $66(0.7)$ & $\nabla$ & $52(0.7)$ & $\nabla$ & $58(0.8)$ & $\nabla$ & $47(0.2)$ & $\nabla$ \\
\hline Netherlands $^{\dagger}$ & $53(1.4)$ & $\nabla$ & $83(1.3)$ & & $52(1.5)$ & $\nabla$ & $53(1.3)$ & $\nabla$ & $47(0.3)$ & $\nabla$ \\
\hline Norway $(9)^{1}$ & 71 (1.0) & $\triangle$ & $91(0.5)$ & $\triangle$ & $69(0.9)$ & $\triangle$ & $66(1.0)$ & & $52(0.2)$ & $\triangle$ \\
\hline Slovenia & $74(1.1)$ & $\triangle$ & $78(0.9)$ & $\nabla$ & 65 (1.2) & $\triangle$ & $71(1.0)$ & $\triangle$ & $50(0.2)$ & \\
\hline Sweden $^{1}$ & $63(1.7)$ & & $80(1.0)$ & $\nabla$ & $62(1.4)$ & & $63(1.2)$ & & $49(0.3)$ & $\nabla$ \\
\hline European ICCS 2016 average & $66(0.3)$ & & $83(0.2)$ & & $63(0.3)$ & & $65(0.3)$ & & $50(0.1)$ & \\
\hline \multicolumn{11}{|c|}{ Benchmarking participant not meeting sample participation requirements } \\
\hline $\begin{array}{l}\text { North-Rhine-Westphalia } \\
(\text { Germany })^{1}\end{array}$ & $66(1.8)$ & & $72(1.6)$ & & $73(2.1)$ & & $64(1.8)$ & & $49(0.5)$ & \\
\hline
\end{tabular}

National ICCS 2016 percentage or average:

A More than 10 percentage points or 3 score points above European ICCS 2016 average

$\triangle$ Significantly above European ICCS 2016 average

$\nabla$ Significantly below European ICCS 2016 average

$\boldsymbol{\nabla}$ More than 10 percentage points or 3 score points below European ICCS 2016 average

Notes:

() Standard errors appear in parentheses. Because results are rounded to the nearest whole number, some totals may appear inconsistent.

(9) Country deviated from International Defined Population and surveyed adjacent upper grade.

† Met guidelines for sampling participation rates only after replacement schools were included.

1 National Defined Population covers $90 \%$ to $95 \%$ of National Target Population. 


\section{References}

Alnæs, K. (2013). Roots of European identity: Challenges and threats. Debates on European identity (2013-2014). Strasbourg, France: Council of Europe. Retrieved from https://rm.coe.int/168046e767

Bellamy, R., Castiglione, D., \& Shaw, J. (2006). Making European citizens: Civic inclusion in a transnational context (one Europe or several?). London, UK: Palgrave.

Bîrzéa, C., Kerr, D., Mikkelsen, R., Froumin, I, Losito, B., Pol, M., \& Sardoc, M. (2004). All-European Study on Education for Democratic Citizenship Policies. Strasbourg, France: Council of Europe.

Bruter, M. (2004a). Civic and cultural components of a European identity: A pilot model of measurement of citizens' levels of European identity. In R. K. Herrmann, T. Risse, \& B. M. Brewer (Eds.), Transnational identities: Becoming European in the EU (pp. 186-213). Lanham, MD: Rowman \& Littlefield Publishers.

Bruter, M. (2004b). On what citizens mean by feeling "European": Perceptions of news, symbols and borderless-ness. Journal of Ethnic and Migration Studies, 30(1), 21-39.

Bruter, M. (2005). Citizens of Europe? The emergence of a mass European identity. Basingstoke, UK: Palgrave Macmillan.

Castano, E. (2004). European identity: A social-psychological perspective. In R. K. Herrmann, T. Risse, \& B. M. Brewer (Eds.), Transnational identities: Becoming European in the EU (pp. 40-58). Lanham, MD: Rowman $\&$ Littlefield Publishers.

Cerutti, F., \& Lucarelli, S. (Eds.). (2008). The search for a European identity: Values, policies, and legitimacy of the European Union. London, UK and New York, NY: Routledge.

Checkel, J. T., \& Katzenstein, P. J. (2009). European identity. Cambridge, UK: Cambridge University Press.

Citrin, J., \& Sides, J. (2004). More than nationals: How identity choice matters in the new Europe. In R. K. Herrmann, T. Risse, \& B. M. Brewer (Eds.), Transnational identities: Becoming European in the EU (pp. 161-185). Lanham, MD: Rowman \& Littlefield Publishers.

Delanty, G. (1995). Inventing Europe: Idea, identity, reality. London, UK: Palgrave Macmillan.

Delanty, G., \& Rumford, C. (2005). Rethinking Europe: Social theory and the implications of Europeanization. London, UK: Routledge.

Diez Medrano, J., \& Gutierrez, P. (2001). Nested identities: National and European identity in Spain. Ethnic and Racial Studies, 24(4), 753-778.

Duchesne, S. (2008). Waiting for a European identity: Reflections on the process of identification with Europe. Perspectives on European Politics and Society, 9(4), 397-410.

European Commission. (2012). The development of European identity/identities: Unfinished business. A policy review. Brussels, Belgium: Author. Retrieved from https://ec.europa.eu/research/social-sciences/pdf/ policy_reviews/development-of-european-identity-identities_en.pdf

European Commission. (2016). Standard Eurobarometer 85 "European citizenship" report. Brussels, Belgium: Author. Retrieved from http://ec.europa.eu/COMMFrontOffice/publicopinion/index.cfm/Survey/ getSurveyDetail/instruments/STANDARD/surveyKy/2130

Eurydice. (2005). Citizenship education at school in Europe. Brussels, Belgium: Author.

Eurydice. (2012). Citizenship education in Europe. Brussels, Belgium: Author.

Fligstein, N., Polyakova, A., \& Sandholtz, W. (2012). European integration, nationalism and European identity. Journal of Common Market Studies, 50(1), 106-122.

Herrmann, R. K., \& Brewer, B. M. (2004). Identities and institutions: Becoming European in the EU. In R. K. Herrmann, T. Risse, \& B. M. Brewer (Eds.), Transnational identities: Becoming European in the EU (pp. 1-25). Lanham, MD: Rowman \& Littlefield Publishers.

Karolewski, I. P., \& Kaina, V. (2006). European identity: Theoretical perspectives and empirical insights. Berlin, Germany: LIT Verlag.

Keating, A. (2014). Education for citizenship in Europe: European policies, national adaptations and young people's attitudes. London, UK: Routledge.

Kerr, D., Sturman, L., Schulz, W., \& Burge, B. (2010). ICCS 2009 European report: Civic knowledge, attitudes and engagement among lower secondary school students in twenty-four European countries. Amsterdam, the Netherlands: International Association for the Evaluation of Educational Achievement (IEA).

Lehning, P. B. (2001). European citizenship: Towards a European identity? Law and Philosophy, 20(3), 239-282. 
Lepsius, M. R. (2001). The European Union: Economic and political integration and cultural plurality. In K. Eder \& B. Giesen (Eds.), European citizenship: Between national legacies and post-national projects (pp. 205-221). Oxford, UK: Oxford University Press.

Nicaise, J., \& Blondin, C. (2003). The European dimension in secondary education in Europe: A comparative study of the place occupied by the European Union in the secondary education curriculum in the member states and in the candidate countries (Education and Culture Series EDUC 113 EN). Luxembourg: European Parliament. Retrieved from http://bookshop.europa.eu/en/the-european-dimension-in-secondary-education-in-europe-pbQAEDUC113/

Pichler, F. (2008). European identities from below: Meanings of identification with Europe. Perspectives on European Politics and Society, 9(4), 411-430.

Risse, T. (2010). A community of Europeans? Transnational identities and public spheres. Ithaca, NY and London, UK: Cornell University Press.

Schilde, K. E. (2014). Who are the Europeans? European identity outside of European integration. Journal of Common Market Studies, 52(3), 650-667.

Schulz, W., Ainley, J., Fraillon, J., Kerr, D., \& Losito, B. (2010). ICCS 2009 international report: Civic knowledge, attitudes and engagement among lower secondary school students in thirty-eight countries. Amsterdam, the Netherlands: International Association for the Evaluation of Educational Achievement (IEA).

Schulz, W., Ainley, J., Fraillon, J., Losito, B., \& Agrusti, G. (2016). IEA International Civic and Citizenship Education Study 2016: Assessment framework. Cham, Switzerland: Springer.

Schulz, W., Ainley, J., Fraillon, J., Losito, B., Agrusti, G., \& Friedman, T. (2018). Becoming citizens in a changing world: IEA International Civic and Citizenship Education Study 2016 international report. Cham, Switzerland: Springer.

Spannring, R., Wallace, C., \& Datler, G. (2008). What leads young people to identify with Europe? An exploration of the impact of exposure to Europe and political engagement on European identity among young Europeans. Perspectives on European Politics and Society, 9(4), 480-498.

Van Driel, B., Darmody, M., \& Kerzil, J. (2016). Education policies and practices to foster tolerance, respect for diversity and civic responsibility in children and young people in the EU (NESET II report). Luxembourg: Publications Office of the European Union. Retrieved from http://ec.europa.eu/dgs/education_culture/ repository/education/library/study/2016/neset-education-tolerance-2016_en.pdf

Veugelers, W., de Groot, I., \& Stolk, V. (2017). Research for CULT Committee: Teaching common values in Europe. Brussels, Belgium: European Parliament Policy Department for Structural and Cohesion Policies. Retrieved from http://www.europarl.europa.eu/RegData/etudes/STUD/2017/585918/IPOL_STU(2017)585918_EN.pdf Westle, B., \& Segatti, P. (Eds.). (2016). European identity in the context of national identity: Questions of identity in sixteen European countries in the wake of the financial crisis. Oxford, UK: Oxford University Press.

Open Access This chapter is licensed under the terms of the Creative Commons Attribution-NonCommercial 4.0 International License (http://creativecommons.org/licenses/by-nc/4.0/), which permits any noncommercial use, sharing, adaptation, distribution and reproduction in any medium or format, as long as you give appropriate credit to the original author(s) and the source, provide a link to the Creative Commons license and indicate if changes were made.

The images or other third party material in this chapter are included in the chapter's Creative Commons license, unless indicated otherwise in a credit line to the material. If material is not included in the chapter's Creative Commons license and your intended use is not permitted by statutory regulation or exceeds the permitted use, you will need to obtain permission directly from the copyright holder. 


\section{CHAPTER 3:}

\section{Students' attitudes toward freedom of movement and immigration in Europe}

\section{Chapter highlights and summary}

Surveyed students endorsed freedom of movement for European citizens within Europe.

- Large majorities of students across the European participating countries strongly agreed or agreed with statements regarding freedom of movement for European citizens within Europe and tended to strongly disagree or disagree with statements regarding restriction of movement. (Table 3.1)

- Strong variation across countries was observed for statements on restriction of movement. (Table 3.1)

- Students with a higher level of civic knowledge (at or above Level B on the civic knowledge scale) were more in favor of freedom of movement than were students with a lower level of civic knowledge (below Level B). (Tables 3.2, 3.3).

- Male students were more in favor than female students of restricting freedom of movement. (Table 3.3)

Differences related to students' endorsement of equal rights for immigrants were evident across the European participating countries.

- Most students largely agreed with statements regarding immigrants' rights. (Table 3.5)

- Most of the European participating countries recorded no strong difference between their ICCS 2009 students' and their ICCS 2016 students' attitudes toward equal rights for immigrants. (Table 3.6)

- In all countries, female students held more positive attitudes toward immigrants' rights than males did. (Table 3.7)

- In most countries, students from an immigrant family expressed more positive attitudes toward immigrant rights than students from a non-immigrant family did. (Table 3.7)

- Students' attitudes toward equal rights for immigrants were associated with higher levels of civic knowledge (at or above Level B). (Table 3.7) 
This chapter provides findings on students' attitudes toward European citizens having the freedom of movement that allows them to work and live throughout Europe. The chapter also considers findings on students' attitudes toward equal rights for immigrants (e.g., voting, education). These constructs reflect the content domain related to students' attitudes toward civic principles that is included in the affective-behavioral dimension of the ICCS 2016 assessment framework (Schulz, Ainley, Fraillon, Losito, \& Agrusti, 2016).

\section{Students' attitudes toward freedom and restriction of movement for European citizens within Europe}

Freedom of movement and residence for persons in the European Union (EU) has underpinned the development of EU citizenship since the Treaty of Maastricht in 1992, which had as its ultimate aim the creation of an integrated economic area for EU citizens. The provisions that support the right of persons to move and reside freely within the territory of the EU member states are included in Directive 2004/38/EC.

The European Commission's annual report of 2016 on workforce mobility within the EU showed that, in 2015, almost 12.5 million EU-28 citizens of working age were residing in a member state other than their country of citizenship within the EU/EFTA region. ${ }^{1}$ Six countries were hosting almost 75 percent of the EU-28 movers: Germany (2.7 million), the United Kingdom (2.1 million), Spain (1.4 million), Italy (1.1 million), and France and Switzerland (both around 950,000). The countries with the highest proportions of the EU-28 movers in relation to the overall population were Luxembourg (43\%), Switzerland (19\%), Cyprus (15\%), Ireland (10\%), and Belgium (14\%) (Fries-Tersch, Tugran, \& Bradley, 2016).

In the EU citizens' consultation of 2015 (European Commission, 2016a), about 2,100 respondents from 18 to 71-plus years of age shared their experiences of EU citizenship. According to this consultation, almost all respondents declared that they had moved freely in the EU once in their lifetime. They listed holidays as the main reason for moving, followed by work-related reasons and visiting family or friends. Respondents also expressed positive opinions about free movement, agreeing that it promotes cultural diversity (81\% of respondents), fosters mutual understanding (77\%), creates an EU identity (70\%), and brings economic growth (61\%).

Findings from the Standard Eurobarometer 85 survey (European Commission, 2016b) also highlighted general positive feelings toward free movement, with respondents considering the free movement of people, goods, and services within the EU as the union's most positive feature. Of the European countries participating in ICCS 2016, Bulgaria, Croatia, Estonia, Finland, Latvia, Lithuania, the Netherlands, and Sweden all recorded majorities of respondents (60 percent on average) agreeing or strongly agreeing that free movement within the EU is the EU's most positive outcome. In Belgium, Italy, and Malta, however, less than 50 percent of respondents believed that free movement is the EU's most positive result.

The ICCS 2016 European regional questionnaire included a six-item question designed to elicit students' attitudes toward European citizens having freedom to pursue work in EU member countries or toward having that freedom restricted. Although used in ICCS 2009, this question was heavily modified for ICCS 2016.

Three of the six items related to students' attitudes toward freedom of movement within Europe: (a) "Allowing citizens of European countries to work anywhere in Europe is good for the European economy;" (b) "Citizens of European countries should be allowed to work anywhere in Europe;" and (c) "Allowing citizens of European countries to work anywhere in Europe helps to reduce unemployment."

1 The European Free Trade Organization is an inter-governmental organization aimed at promoting free trade and economic integration among its four member states: Iceland, Liechtenstein, Norway, and Switzerland. 
The remaining three items focused on students' attitudes toward restriction of migration within Europe: (d) "Citizens of European countries should be allowed to work in another European country only if their skills are needed there;" (e) "Citizens of European countries who wish to work in another country should be allowed to take only the jobs that no one in the other country wants to do;" and (f) "Only a limited number of people should be allowed to move for work from one European country to another."

Students were asked to "strongly agree," "agree," "disagree," or "strongly disagree" with the six statements. The resulting scales had an average reliability at the international level-Cronbach's alpha of 0.74 for students' attitudes toward freedom of movement within Europe, and 0.63 for students' attitudes toward restriction of movement within Europe (see item maps in Figures 3.1 and 3.2, Appendix C).

Nearly all surveyed students agreed with the three statements related to freedom of movement within Europe. On average across the European countries, 94 percent of students thought that allowing citizens of European countries to work anywhere in Europe is good for the European economy (see Table 3.1). Students also expressed general agreement with the items stating that citizens of European countries should be allowed to work anywhere in Europe (European ICCS 2016 average: 92\%) and that allowing citizens of European countries to work anywhere in Europe helps to reduce unemployment (European ICCS 2016 average: 89\%).

On average, the country percentages were lower for the remaining items on restriction of movement (63\% for item d and about 37\% for items e and f). These results indicate a general tendency among the participating students to endorse freedom of movement throughout the countries of Europe.

Students' agreement with the statement that citizens of European countries should be allowed to work in another European country only if their skills are needed ranged from averages of 45 percent to 87 percent. The national percentages of agreement with this item were particularly high in Bulgaria, Croatia, and Norway; the lowest such percentages were found in Belgium (Flemish), Finland, the Netherlands, and Slovenia.

On average across the European participating countries, 36 percent of students agreed with the statement that European citizens wanting to work in another country should be allowed to take only the jobs that no one else in that country wanted to do. The national average percentages of students agreeing with this statement ranged from 23 percent to 54 percent. The percentages in Malta, Norway, and Sweden were more than 10 points above the European ICCS 2016 average. Finland and Latvia recorded the lowest percentages.

The national average percentages for students' agreement with the statement that only a limited number of people should be allowed to move for work from one European country to another were also on the low side (European ICCS 2016 average: 37\%). The only country where the national agreement percentage was more than 10 points above the European ICCS 2016 average was Belgium (Flemish). The percentages in Denmark, Lithuania, Malta, and Norway were significantly above the European ICCS 2016 average. The lowest recorded percentage was in Estonia, while Croatia, Finland, and Italy recorded percentages significantly below the European ICCS 2016 average.

Table 3.2 shows the associations between students' attitudes toward freedom of movement within Europe and variables reflecting students' gender, students' background (from an immigrant family or from a non-immigrant family), and civic knowledge. We found no significant differences between gender groups and between students from an immigrant family or from a non-immigrant family. In all but two countries, students at or above Level B on the civic knowledge scale showed significantly higher scale scores than the students below Level B (about three scale score points on average). The two countries that recorded no significant differences for these variables were Belgium (Flemish) and the Netherlands. 

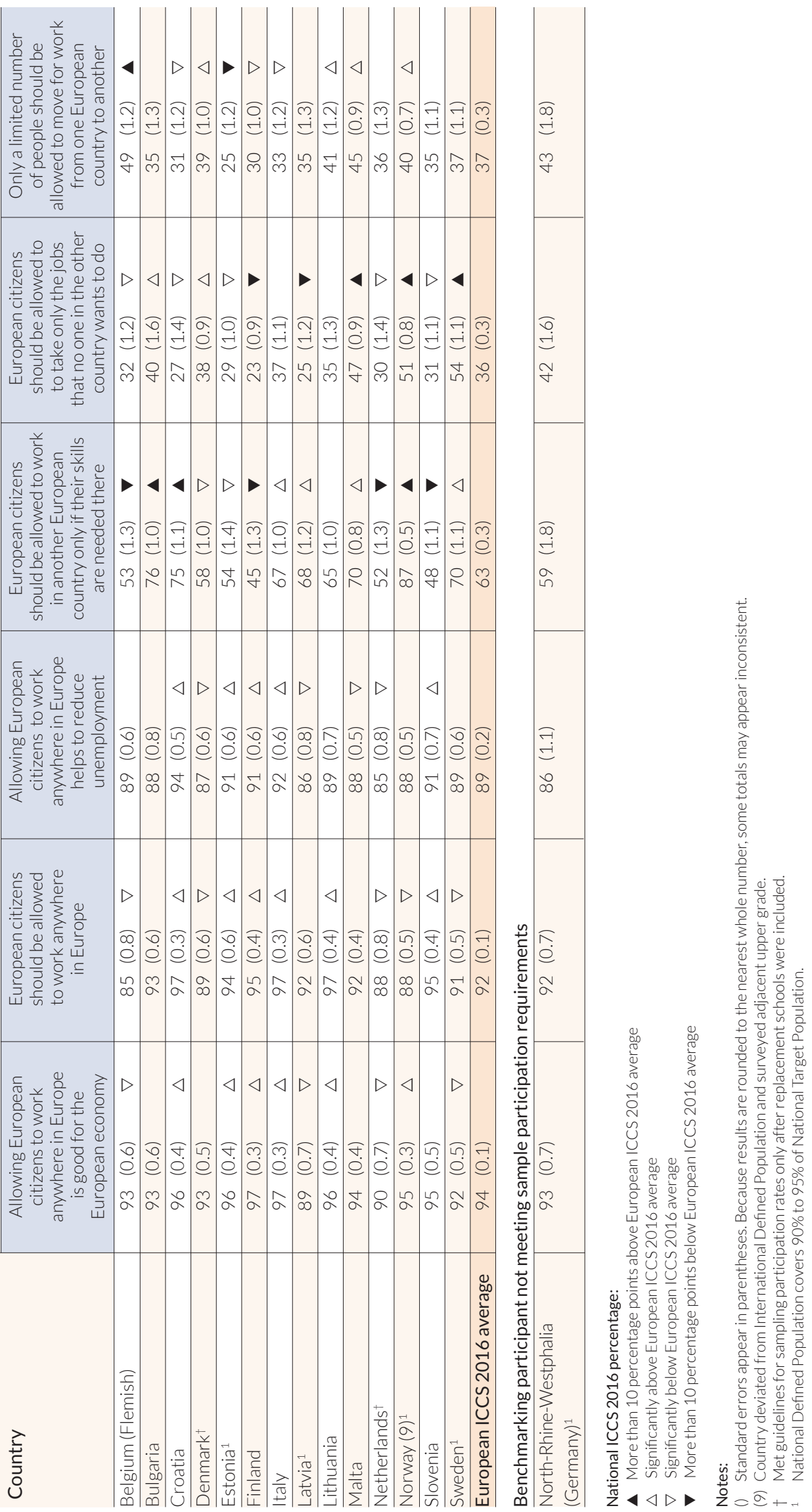


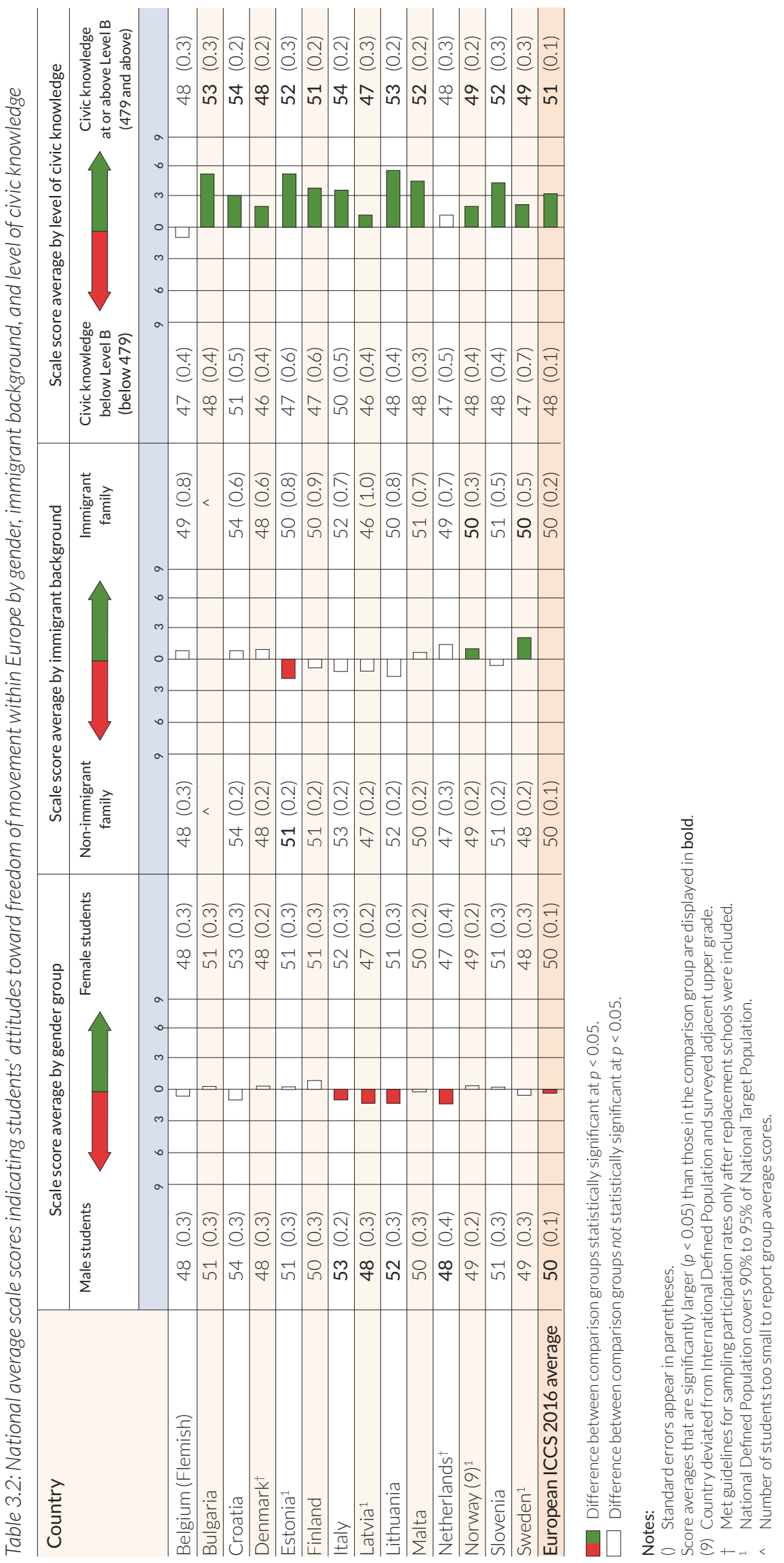


When we looked for potential associations between students' attitudes toward restriction of movement within Europe and students' gender, we found strong significant differences between male and female students in all countries, with males being more in favor than females of restriction (see Table 3.3). On average, we observed a difference of three scale score points across countries. In several countries, namely Belgium (Flemish), Denmark, Estonia, Finland, Norway, Slovenia, and Sweden, students from an immigrant family were more likely to agree with statements on restriction of movement than the students from a non-immigrant family were (Table 3.3). ${ }^{2}$ Compared to students with a lower level of civic knowledge (below Level B), students at or above Level B of the civic knowledge scale were the students less in favor of restriction of movement. On average, the difference was seven scale points.

\section{Students' attitudes toward immigration}

During 2015, 4.7 million people migrated to one of the EU-28 member states (Eurostat, 2017). Among these people, according to the Eurostat estimates, were 2.7 million citizens of non-member countries and 1.9 million people whose citizenship was not that of the EU member state to which they migrated.

On average, the people who answered the 2016 Standard Eurobarometer 86 survey (EB86) (European Commission, 2016c) considered immigration to be the most important issue at the European level, followed by terrorism. (The percentage for immigration had dropped by 13 percentage points since the 2015 survey, however.) Among the European countries participating in ICCS 2016, more than 60 percent of respondents in Estonia, Malta, and Bulgaria identified immigration as the most relevant issue. The national percentages for immigration as the main issue were between 50 and 60 percent in Denmark, Latvia, Lithuania, the Netherlands, Slovenia, and Sweden.

In EB86, a large majority of the 2016 respondents (61\%) regarded immigration of people from other EU member states positively. However, 56 percent of respondents expressed negativity about people from outside the EU immigrating to EU member states, although the proportion of respondents who considered this kind of immigration in a positive way increased in the interval between the 2015 and 2016 surveys.

Of the European countries participating in ICCS 2016, those where respondents felt most positive about immigration of people from other EU member states were Sweden, Finland, and Lithuania. Countries where respondents expressed predominantly negative feelings were Latvia and Italy. As for immigration of people from outside the EU, majorities of respondents in Estonia, Latvia, and Bulgaria felt negative about this development. Of the European countries participating in ICCS, Sweden was the country that recorded the lowest average percentage of negative feelings.

Findings from the European Social Survey suggested that public attitudes toward immigration are closely linked to people's educational backgrounds (Masso, 2009; Paas \& Halapuu, 2012) and that young people and people with higher levels of education show more favorable attitudes toward immigrants than older and lesser educated people do. Both the 2016 EB86 survey (European Commission, 2016c) and the European Social Survey found that Europeans prefer migrants from the same racial or ethnic group as themselves and tend to hold negative feelings toward migrants from poorer countries outside Europe. In relation to the effects of migration, Europeans emphasized migration's negative impact on their daily lives (e.g., crime and the quality of health and welfare services). General issues related to culture aroused less concern, although comparisons showed a slight strengthening in this concern over time (Heath \& Richards, 2016).

2 As mentioned in the previous chapter, students from an immigrant family generally also came from a lower socioeconomic background than students from a non-immigrant family did. 


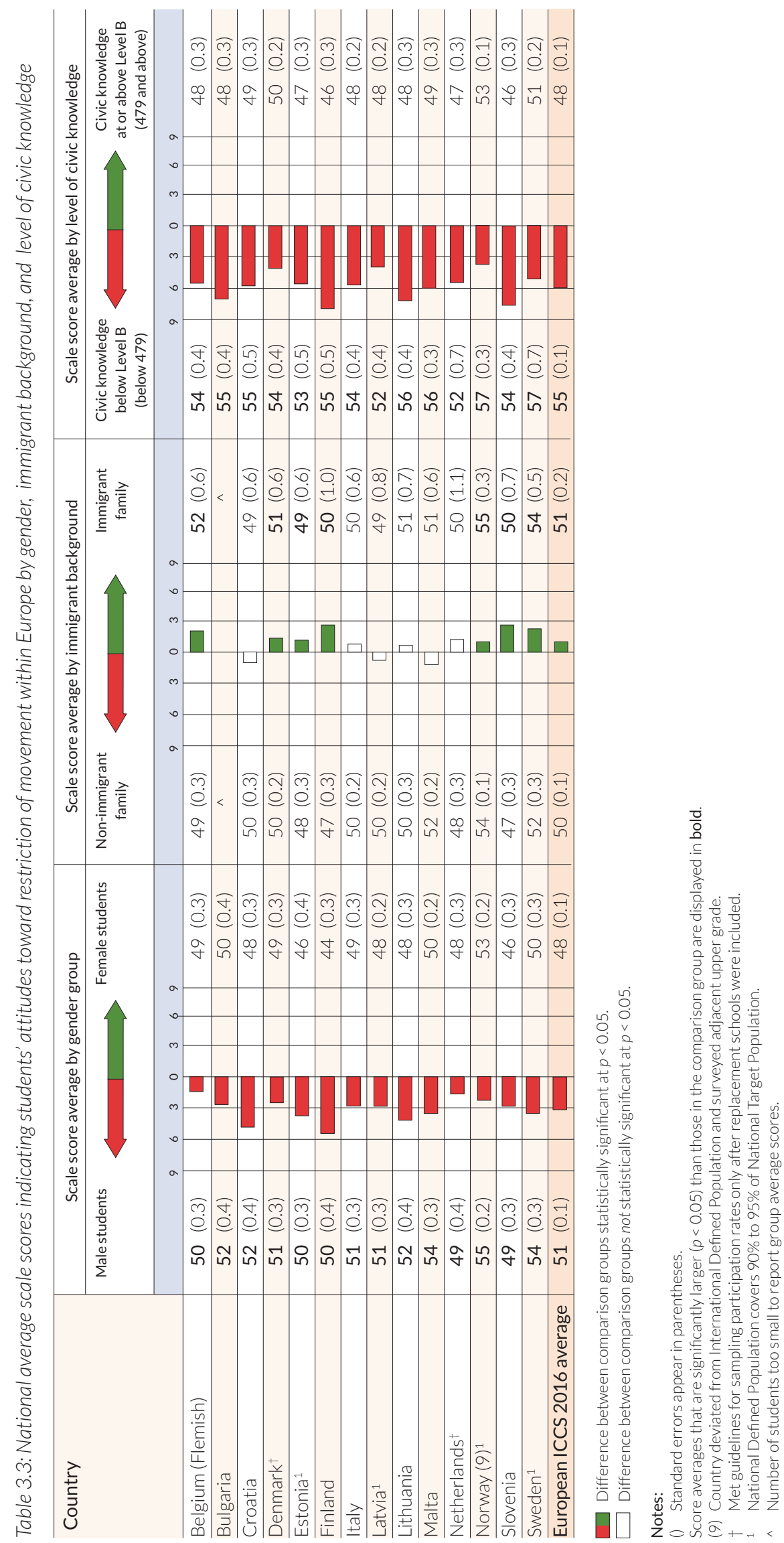


Some studies analyzing adolescents' attitudes toward immigrants have highlighted how parents' and peers' tolerance and xenophobia as well as inter-group friendships affect relative changes in students' pro-immigrant and anti-immigrant attitudes (Davies, Tropp, Aron, Pettigrew, \& Wright, 2011; Degner \& Dalege, 2013; Gniewosz \& Noack, 2015; Miklikowska, 2017; van Zalk, Kerr, van Zalk, \& Stattin, 2013).

Research investigating adolescents' attitudes toward immigrants' rights and nationalism has shown that greater religious diversity and more restrictive citizenship policies tend to be associated with adolescents' lower levels of support for immigrants' rights (Barber, Fennelly, \& Torney-Purta, 2013). Research findings also highlight that adolescent females tend to hold more positive attitudes than adolescent males toward immigrant rights (Amadeo, Torney-Purta, Lehmann, Husfeldt, \& Nikolova, 2002; Diaz-Veizades, Widaman, Little, \& Gibbs, 1995; Torney-Purta, Lehmann, Oswald, \& Schulz, 2001; Toth, 1995; Watts, 1996; Westin, 1998).

The IEA Civic Education Study (CIVED 1999) used eight items to measure attitudes toward immigrants. Five of these items were included in a scale (Schulz, 2004). Students at both lower and upper secondary school level reported mostly positive attitudes toward immigrants' rights (Amadeo et al., 2002; Torney-Purta et al., 2001). The ICCS 2009 student questionnaire encompassed a slightly modified version of the five items used in the CIVED scale. The results showed that students from an immigrant family expressed higher levels of endorsement for equal rights and opportunities for immigrants than students from a non-immigrant family did (Schulz, Ainley, Fraillon, Kerr, \& Losito, 2010).

For ICCS 2016, we included, because of the particular relevance of this topic for the European context, a question in the student questionnaire that measured students' endorsement of equal rights for immigrants. The rationale behind this question was to measure students' endorsement of the principle of providing equal rights and opportunities to immigrants. Because many ICCS countries have very little immigration, the items referred to immigration to any country, not just to the one the students were living in.

The following five Likert-type items (with response categories "strongly agree," "agree," "disagree," "strongly disagree") were used to measure the European students' attitudes toward equal rights for immigrants: (a) "Immigrants should have the opportunity to continue speaking their own language;" (b) "Immigrant children should have the same opportunities for education that other children in the country have;" (c) "Immigrants who live in a country for several years should have the opportunity to vote in elections;" (d) "Immigrants should have the opportunity to continue their own customs and lifestyle;" and (e) "Immigrants should have all the same rights that everyone else in the country has." These five items formed a scale with a high average reliability for the combined international sample (Cronbach's alpha $=0.80$ ), with the higher scores on the scale reflecting greater endorsement of equal opportunities for immigrants (see the item map in Figure 3.3, Appendix C).

On average, majorities of students agreed that immigrant children should have the same opportunities for education that other children in the country have (European ICCS 2016 average: 93\%), and that immigrants should have all the same rights that everyone else in the country has (European ICCS 2016 average: 88\%). The statements on immigrants being able to vote in elections, continue their own customs and lifestyle, and continue speaking their own language recorded lower percentages of agreement (European ICCS 2016 averages respectively of 75\%,73\%, and 68\%) (see Table 3.4).

In the European countries that participated in both ICCS 2009 and 2016, the average student tended to agree with statements endorsing equal rights for immigrants. In Sweden, country mean scores were more than three points above the European ICCS 2016 average. Latvia recorded the lowest national average (Table 3.5). 
Table 3.4: Students' attitudes toward equal rights for immigrants

\begin{tabular}{|c|c|c|c|c|c|c|c|c|c|c|}
\hline \multirow{3}{*}{$\begin{array}{l}\text { Country } \\
\text { Belgium (Flemish) }\end{array}$} & \multicolumn{10}{|c|}{$\begin{array}{l}\text { Percentages of students who agreed or strongly agreed with the } \\
\text { following statements: }\end{array}$} \\
\hline & \multicolumn{2}{|c|}{$\begin{array}{c}\text { Immigrants should } \\
\text { have the } \\
\text { opportunity } \\
\text { to continue } \\
\text { speaking their } \\
\text { own language }\end{array}$} & \multicolumn{2}{|c|}{$\begin{array}{l}\text { Immigrant children } \\
\text { should have the } \\
\text { same opportunities } \\
\text { for education that } \\
\text { other children in } \\
\text { the country have }\end{array}$} & \multicolumn{2}{|c|}{$\begin{array}{l}\text { Immigrants who } \\
\text { live in a country } \\
\text { for several years } \\
\text { should have the } \\
\text { opportunity to } \\
\text { vote in elections }\end{array}$} & \multicolumn{2}{|c|}{$\begin{array}{l}\text { Immigrants should } \\
\text { have the } \\
\text { opportunity to } \\
\text { continue their own } \\
\text { customs and } \\
\text { lifestyle }\end{array}$} & \multicolumn{2}{|c|}{$\begin{array}{l}\text { Immigrants should } \\
\text { have the same } \\
\text { rights that } \\
\text { everyone else in } \\
\text { the country has }\end{array}$} \\
\hline & $58(1.2)$ & $\nabla$ & $94(0.5)$ & $\triangle$ & 77 (1.0) & $\triangle$ & $66(1.2)$ & & $88(0.8)$ & \\
\hline Bulgaria & $71(1.2)$ & $\triangle$ & $86(0.9)$ & $\nabla$ & 55 (1.4) & $\nabla$ & $75(1.1)$ & $\triangle$ & $76(1.1)$ & $\nabla$ \\
\hline Croatia & 79 (1.1) & $\Delta$ & $95(0.5)$ & $\triangle$ & $78(1.0)$ & $\triangle$ & $84(0.9)$ & $\Delta$ & $92(0.7)$ & $\triangle$ \\
\hline Denmark $^{\dagger}$ & $60(1.0)$ & $\nabla$ & $95(0.4)$ & $\triangle$ & $86(0.7)$ & $\Delta$ & $78(1.0)$ & $\triangle$ & $90(0.7)$ & $\triangle$ \\
\hline Estonia $^{1}$ & $62(1.2)$ & $\nabla$ & $94(0.5)$ & & $68(1.1)$ & $\nabla$ & $59(1.1)$ & $\nabla$ & $85(0.8)$ & $\nabla$ \\
\hline Finland & $68(1.0)$ & & $91(0.7)$ & $\nabla$ & $78(0.9)$ & $\triangle$ & $65(1.0)$ & $\nabla$ & $89(0.7)$ & $\triangle$ \\
\hline Italy & $65(1.0)$ & $\nabla$ & $94(0.5)$ & $\triangle$ & $76(1.1)$ & & $73(1.0)$ & & $92(0.6)$ & $\triangle$ \\
\hline Latvia $^{1}$ & $50(1.3)$ & $\nabla$ & $88(0.7)$ & $\nabla$ & 58 (1.3) & $\nabla$ & $54(1.4)$ & $\nabla$ & $78(1.0)$ & $\nabla$ \\
\hline Lithuania & $80(1.0)$ & $\Delta$ & $95(0.5)$ & $\triangle$ & $70(1.0)$ & $\nabla$ & $82(0.8)$ & $\triangle$ & $88(0.7)$ & \\
\hline Malta & $79(0.9)$ & $\Delta$ & $90(0.6)$ & $\nabla$ & $67(0.9)$ & $\nabla$ & $72(0.8)$ & & $83(0.7)$ & $\nabla$ \\
\hline${ }_{\text {Netherlands }}^{\dagger}$ & $51(1.5)$ & $\nabla$ & $92(0.5)$ & & $80(0.9)$ & $\triangle$ & $70(1.2)$ & $\nabla$ & $87(0.9)$ & \\
\hline Norway $(9)^{1}$ & $76(0.9)$ & $\triangle$ & $96(0.3)$ & $\triangle$ & $84(0.6)$ & $\triangle$ & $81(0.7)$ & $\triangle$ & $92(0.4)$ & $\triangle$ \\
\hline Slovenia & $73(1.2)$ & $\triangle$ & $95(0.4)$ & $\triangle$ & $82(0.9)$ & $\triangle$ & $79(1.0)$ & $\triangle$ & $92(0.7)$ & $\triangle$ \\
\hline Sweden $^{1}$ & $82(1.2)$ & $\Delta$ & $95(0.5)$ & $\triangle$ & $88(0.9)$ & $\Delta$ & $83(1.0)$ & $\triangle$ & $94(0.7)$ & $\triangle$ \\
\hline European ICCS 2016 average & $68(0.3)$ & & $93(0.1)$ & & $75(0.3)$ & & $73(0.3)$ & & $88(0.2)$ & \\
\hline \multicolumn{11}{|c|}{ Benchmarking participant not meeting sample participation requirements } \\
\hline $\begin{array}{l}\text { North-Rhine-Westphalia } \\
(\text { Germany })^{1}\end{array}$ & $82(1.3)$ & & $93(0.8)$ & & $83(1.2)$ & & $79(1.3)$ & & $92(1.0)$ & \\
\hline
\end{tabular}

National ICCS 2016 percentage:

- More than 10 percentage points above European ICCS 2016 average

$\triangle$ Significantly above European ICCS 2016 average

$\nabla$ Significantly below European ICCS 2016 average

$\boldsymbol{\nabla}$ More than 10 percentage points below European ICCS 2016 average

Notes:

() Standard errors appear in parentheses. Because results are rounded to the nearest whole number, some totals may appear inconsistent.

(9) Country deviated from International Defined Population and surveyed adjacent upper grade.

+ Met guidelines for sampling participation rates only after replacement schools were included.

National Defined Population covers $90 \%$ to $95 \%$ of National Target Population.

Between ICCS 2009 and 2016, the national scores on the students' attitudes toward immigrants scale decreased in four countries-Bulgaria, Estonia, Latvia, and Lithuania. We recorded small significant increases in Belgium (Flemish), and Norway. The country with the highest increase in average scores between 2009 and 2016 was Norway (2.8 score points). The strongest decrease was found in Bulgaria (-5.6 score points). As shown in Table 3.5, the European average for common countries in ICCS 2016 was slightly lower than in 2009-by more than half a score point.

In all participating countries, female students generally held more positive attitudes toward immigrant rights than males did (see Table 3.6). The statistically significant difference was two score points on average. In nine countries, students from an immigrant family expressed more positive attitudes toward immigrant rights than did those from a non-immigrant family. The statistically significant scale point difference was about three score points on average. The highest differences that we recorded (four score points or more) were for Belgium (Flemish), Denmark, Finland, Italy, the Netherlands, Norway, and Sweden.

In every country, students' scores on the scale were greater for students with a higher level of civic knowledge scores (at or above Level B) than for students with a lower level of civic knowledge (below Level B). On average, the difference was about two scale points. 
Table 3.5: National averages of students' endorsement of equal rights for immigrants

\begin{tabular}{|c|c|c|c|c|c|c|c|c|c|}
\hline Country & 2016 & & 2009 & $\begin{array}{c}\text { Differences } \\
(2016-2009)\end{array}$ & 40 & 45 & 50 & 55 & 60 \\
\hline Belgium (Flemish) & $47(0.2)$ & $\nabla$ & $46(0.3)$ & $1.6(0.8)$ & & $\square \square$ & & & \\
\hline Bulgaria & $46(0.3)$ & $\nabla$ & $52(0.2)$ & $-5.6(0.7)$ & & $\square$ & $\mathbf{\square}$ & & \\
\hline Croatia & $50(0.2)$ & $\triangle$ & - & - & & 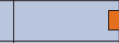 & 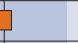 & & \\
\hline Denmark $^{\dagger}$ & $49(0.2)$ & & $48(0.3)$ & $0.0(0.7)$ & & $\square$ & & & \\
\hline Estonia $^{1}$ & $46(0.1)$ & $\nabla$ & $48(0.2)$ & $-1.7(0.7)$ & & $\square$ & & & \\
\hline Finland & $48(0.2)$ & $\nabla$ & $48(0.3)$ & $-0.2(0.7)$ & & $\square$ & & & \\
\hline Italy & $49(0.2)$ & & $48(0.3)$ & $0.1(0.8)$ & & $\square$ & & & \\
\hline Latvia $^{1}$ & $43(0.2)$ & $\nabla$ & $47(0.2)$ & $-3.4(0.7)$ & $\square$ & - & & & \\
\hline Lithuania & $49(0.2)$ & $\triangle$ & $51(0.2)$ & $-1.6(0.7)$ & & $\square$ & $\square$ & & \\
\hline Malta & $48(0.2)$ & & $49(0.3)$ & $-1.0(0.8)$ & & $\square$ & & & \\
\hline Netherlands $^{\dagger}$ & $47(0.3)$ & $\nabla$ & - & - & & $\square$ & & & \\
\hline Norway (9) ${ }^{1}$ & $51(0.2)$ & $\triangle$ & $48(0.4)$ & $2.8(0.8)$ & & $\boldsymbol{D}$ & $\square$ & & \\
\hline Slovenia & $50(0.3)$ & $\triangle$ & $50(0.3)$ & $-0.3(0.8)$ & & E & 7 & & \\
\hline Sweden $^{1}$ & $53(0.4)$ & $\Delta$ & $52(0.4)$ & $1.5(0.9)$ & & & $\square$ & & \\
\hline European ICCS 2016 average & $48(0.1)$ & & & & & & & & \\
\hline Common countries average & $48(0.1)$ & & $48(0.3)$ & $-0.6(0.2)$ & & & & & \\
\hline
\end{tabular}

Benchmarking participant not meeting sample participation requirements

North Rhine-Westphalia

$\underline{(\text { Germany })^{1}}$

$53(0.5)$

National ICCS 2016 average:

A More than 3 score points above European ICCS 2016 average

$\triangle$ Significantly above European ICCS 2016 average

$\nabla$ Significantly below European ICCS 2016 average

$\boldsymbol{\nabla}$ More than 3 score points below European ICCS 2016 average

Notes:

() Standard errors appear in parentheses.

Statistically significant changes $(p<0.05)$ between 2009 and 2016 are displayed in bold.

(9) Country deviated from International Defined Population and surveyed adjacent upper grade.

† Met guidelines for sampling participation rates only after replacement schools were included.

National Defined Population covers $90 \%$ to $95 \%$ of National Target Population.

No comparable data available.
2016 average score + /- Confidence interval

2009 average score + /- Confidence interval

On average across items, students with a score in the range with this color have more than a $50 \%$ probability of indicating:

\begin{tabular}{l}
\hline No strong agreement with positive statements \\
\hline Strong agreement with positive statements \\
\hline
\end{tabular}




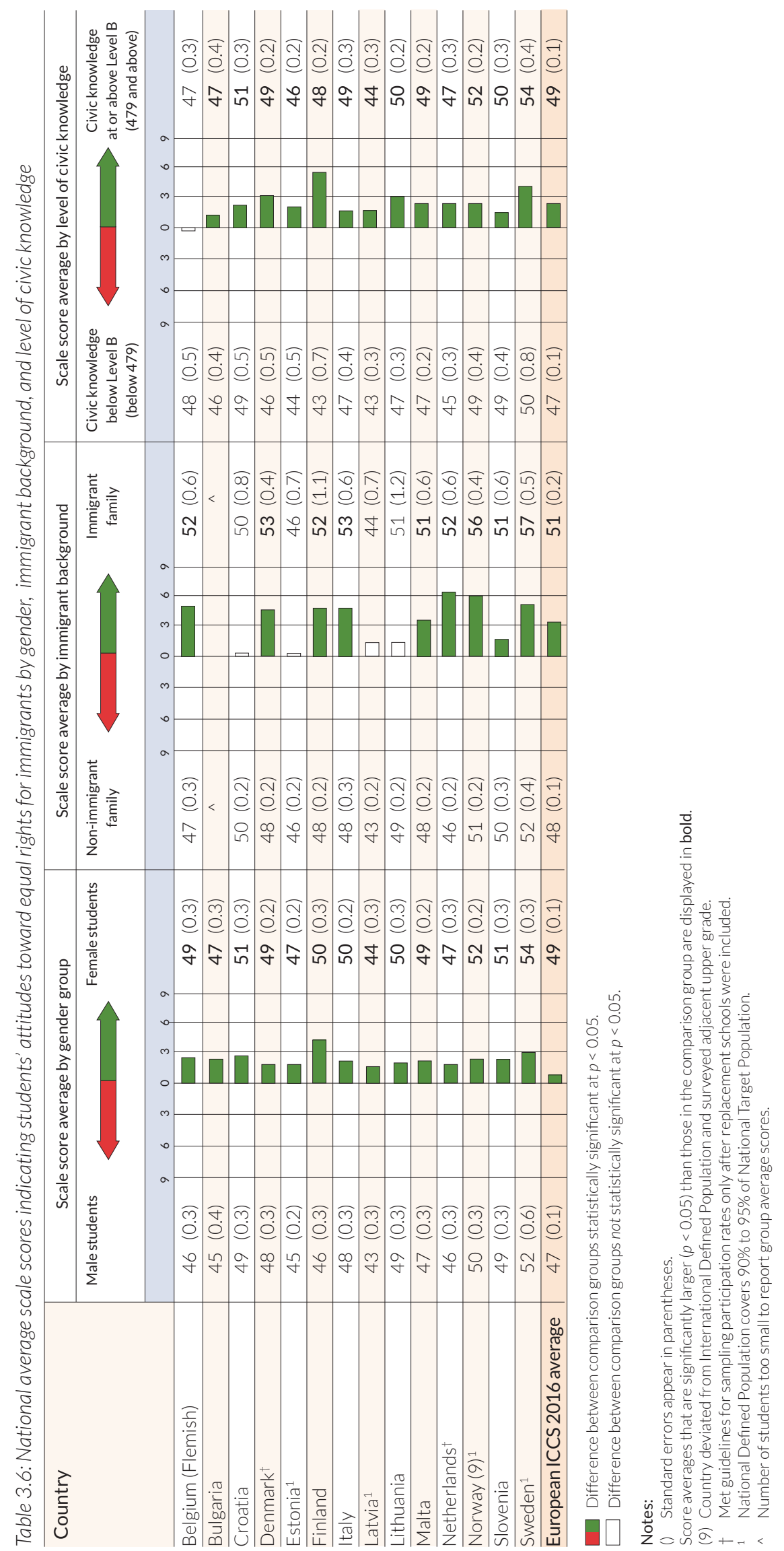




\section{References}

Amadeo, J., Torney-Purta, J., Lehmann, R., Husfeldt, V., \& Nikolova, R. (2002). Civic knowledge and engagement: An IEA study of upper secondary students in sixteen countries. Amsterdam, the Netherlands: International Association for the Evaluation of Educational Achievement (IEA).

Barber, C., Fennelly, K., \& Torney-Purta, J. (2013). Nationalism and support for immigrants' rights among adolescents in 25 countries. Applied Developmental Science, 17(2), 60-75. doi: 10.1080/10888691.2013.774870

Davies, K., Tropp, L. R., Aron, A., Pettigrew, T. F., \& Wright, S. C. (2011). Cross-group friendships and intergroup attitudes: A meta-analytic review. Personality and Social Psychology Review, 15(4), 332-351. doi:10.1177/1088868311411103

Degner, J., \& Dalege, J. (2013).The apple does not fall far from the tree, or does it? A meta-analysis of parentchild similarity in intergroup attitudes. Psychological Bulletin, 139, 1270-1304.doi:10.1037/a0031436

Diaz-Veizades, J., Widaman, K., Little, T., \& Gibbs, K. (1995). The measurement and structure of human rights attitudes. The Journal of Social Psychology, 135(3), 313-328.

European Commission. (2016a). EU citizenship consultation 2015. Common values, rights and democratic participation. Brussels, Belgium: Author. Retrieved from http://ec.europa.eu/justice/citizen/document/ files/2015_public_consultation_booklet_en.pdf

European Commission. (2016b). Standard Eurobarometer 85 "European citizenship" report. Brussels, Belgium: Author. Retrieved from http://ec.europa.eu/COMMFrontOffice/publicopinion/index.cfm/Survey/ getSurveyDetail/instruments/STANDARD/surveyKy/2130

European Commission. (2016c). Standard Eurobarometer 86 "Public opinion in the European Union, first results”. Brussels, Belgium: Author. Retrieved from http://ec.europa.eu/COMM FrontOffice/publicopinion/ index.cfm/Survey/getSurveyDetail/instruments/STANDARD/surveyKy/2137

Eurostat. (2017). Migration and migrant population statistics. Eurostat statistics explained [Website]. Retrieved from http://ec.europa.eu/eurostat/statistics-explained/index.php/migration_and_migrant_ population_statistics

Fries-Tersch, E., Tugran, T., \& Bradley, H. (2016). Annual reporton intra-EU labour mobility: Final report, December 2016. Brussels, Belgium: European Commission. Retrieved from http://ec.europa.eu/social/ BlobServlet?docld $=17165$ \&langld $=$ en

Gniewosz, B., \& Noack, P. (2015). Parental influences on adolescents' negative attitudes toward immigrants. Journal of Youth and Adolescence (online publication). doi:10.1007/s10964-015-0291-3

Heath, A., \& Richards, L. (2016). Attitudes towards immigration and their antecedents: Topline results from Round 7 of the European Social Survey (ESS Topline Results Series, Issue 7). London, UK: European Social Survey. Retrievedfrom http://www.europeansocialsurvey.org/docs/findings/ESS7_toplines_issue_7_immigration.pdf Masso, A. (2009). A readiness to accept immigrants in Europe? Individual and country-level characteristics. Journal of Ethnic and Migration Studies, 35(2), 251-270.

Miklikowska, M. (2017). Development of anti-immigrant attitudes in adolescence: The role of parents, peers, intergroup friendships, and empathy. British Journal of Psychology, 108(3), 626_648. doi:10.1111/bjop.12236

Paas T., \& Halapuu V. (2012). Attitudes towards immigrants and the integration of ethnically diverse societies (NORFACE Migration Discussion Paper No. 2012-23). Retrieved from http://www.norface-migration.org/ publ_uploads/NDP_23_12.pdf

Schulz, W. (2004). Scaling procedures for Likert-type items on students' concepts, attitudes and actions. In W. Schulz \& H. Sibberns (Eds.), IEA Civic Education Study: Technical report (pp. 193-126). Amsterdam, the Netherlands: International Association for the Evaluation of Educational Achievement (IEA).

Schulz, W., Ainley, J., Fraillon, J., Kerr, D., \& Losito, B. (2010). ICCS 2009 international report: Civic knowledge, attitudes and engagement among lower secondary school students in thirty-eight countries. Amsterdam, the Netherlands: International Association for the Evaluation of Educational Achievement (IEA).

Schulz, W., Ainley, J., Fraillon, J., Losito, B., \& Agrusti, G. (2016). IEA International Civic and Citizenship Education Study 2016: Assessment framework. Cham, Switzerland: Springer.

Torney-Purta, J., Lehmann, R., Oswald, H., \& Schulz, W. (2001). Citizenship and education in twenty-eight countries: Civic knowledge and engagement at age fourteen. Amsterdam, the Netherlands: International Association for the Evaluation of Educational Achievement (IEA). 
Toth, O. (1995). Political-moral attitudes amongst young people in post-Communist Hungary. In L. Chisholm, P. Buchner, H.-H. Kruger, \& M. du Bois-Reymond (Eds.), Growing up in Europe: Contemporary horizons in childhood and youth studies (Vol. 2, pp. 189-194). Berlin, New York: Walter de Gruyter.

van Zalk, M.H.W., Kerr, M., van Zalk, N., \& Stattin, H. (2013). Xenophobia and tolerance in adolescence: Cross-Influence processes in friendships. Journal of Abnormal Child Psychology, 41(4), 627-639.

Watts, M. W. (1996). Political xenophobia in the transition from socialism: Threat, racism and ideology among East German youth. Political Psychology, 17(1), 97-126.

Westin, C. (1998). Immigration, xenophobia and youthful opinion. In J. Nurmi (Ed.), Adolescents, cultures and conflicts: Growing up in contemporary Europe (pp. 225-241). New York, NY: Garland Publishing.

Open Access This chapter is licensed under the terms of the Creative Commons Attribution-NonCommercial 4.0 International License (http://creativecommons.org/licenses/by-nc/4.0/), which permits any noncommercial use, sharing, adaptation, distribution and reproduction in any medium or format, as long as you give appropriate credit to the original author(s) and the source, provide a link to the Creative Commons license and indicate if changes were made.

The images or other third party material in this chapter are included in the chapter's Creative Commons license, unless indicated otherwise in a credit line to the material. If material is not included in the chapter's Creative Commons license and your intended use is not permitted by statutory regulation or exceeds the permitted use, you will need to obtain permission directly from the copyright holder. 


\section{CHAPTER 4:}

\section{Students' perceptions of Europe and the future of Europe}

\section{Chapter highlights and summary}

Nearly all surveyed students endorsed cooperation among European countries on specific issues.

- Statements related to cooperation in guaranteeing high levels of employment, strengthening countries' economies, preventing and combating terrorism, and protecting the environment attracted the higher levels of agreement. (Table 4.1)

- Associations between students' views on cooperation among European countries and high civic knowledge scores (at or above Level B on the civic knowledge scale) were observed. (Table 4.2)

Majorities of students expressed positive expectations with respect to Europe's future, although some issues raised concern.

- Students believed that cooperation among European countries would probably increase and that peace and democracy across Europe were likely to strengthen. (Table 4.3)

- Students viewed terrorism and the influence of non-European powers as the most problematic issues. (Table 4.4)

Most students held positive views of the EU

- Majorities of students tended to agree with statements related to the role of the EU in guaranteeing respect for human rights, safety in Europe, protecting the environment, strengthening the economy, and sharing a set of common rules and laws. (see Table 4.5)

- Most of the surveyed students expressed trust in the European Commission and the European Parliament. (Table 4.6)

- Students' expectations of voting in European elections in the future varied across countries. (see Table 4.7)

Nearly all surveyed students had positive perceptions of their own life in the future.

- In most of the participating countries, majorities of students were positive about their respective futures. The extent to which students thought their financial situation would be better than that of their parents varied across countries. (Table 4.8) 
This chapter examines constructs related to students' attitudes toward civic society and systems (i.e., students' attitudes toward European cooperation and the European Union, and students' perceptions of Europe in the future). It also examines a construct related to students' attitudes toward civic identities (i.e., students' perceptions of their own individual future) (Schulz, Ainley, Fraillon, Losito, \& Agrusti, 2016).

\section{Students' attitudes toward cooperation among European countries}

Cooperation among European countries is essential for the ongoing emergence and establishment of a common European space that brings European citizens closely together, enabling them to share ideas and develop solutions to common problems. Results from the Standard Eurobarometer 86 survey (European Commission, 2016a) showed that majorities of Europeans support the development of a common defense and security policy among EU member states and also the development of a common European policy on migration. According to this survey, of the respondents in the ICCS 2016 European countries, almost 90 percent in Sweden and 87 percent in the Netherlands would have agreed that their countries should help refugees. Bulgaria would have recorded the lowest percentage of agreement with this notion.

Another important issue in relation to cooperation among European countries is recognition of educational qualifications achieved in other European countries. Cooperation in this area helps increase young Europeans' voluntary mobility as well as their aspiration to work, study, or undergo training in another EU member country.

In 2014, an opinion survey was conducted among 13,437 young Europeans between 16 and 30 years of age in the $28 \mathrm{EU}$ member states. The survey was part of the 2014 European Youth Event (EYE) organized by the European Parliament (Flash Eurobarometer of the European Parliament, 2014). The survey found that approximately four in 10 young people (43\%) aspired to freedom of mobility. Among the ICCS 2016 European countries, this aspiration was shared mostly by Slovenia, Estonia, and Italy, with around 60 percent of respondents stating that they wanted freedom of mobility. Young people from Belgium and the Netherlands recorded the lowest percentages in relation to this matter. Around 30 percent of respondents expressed a wish to work, study, or undergo training in another EU country (European Parliament, 2014).

The Flash Eurobarometer survey of 2014 showed that about 26 percent of young respondents felt they would be compelled to move (i.e., go to another EU country to study or work) due to the financial crisis in various European countries. Of the respondents in the ICCS 2016 European countries, around 40 percent in each of Slovenia, Italy, and Bulgaria would have held this view of mobility, as would 53 percent (the highest percentage) of respondents in Croatia. ICCS 2016 European countries with lower unemployment rates recorded lower percentages of young people feeling compelled to move. This would have been the case for Belgium, Denmark, the Netherlands, Finland, and Sweden, where more than 90 percent of young respondents anticipated that they would not be forced to move (European Parliament, 2014).

Another relevant issue raised at the European level concerns cooperation among European countries in dealing with the recent mass-movement of refugees. From 2014, Europe has experienced the greatest mass movement of people seeking asylum since the Second World War, the majority of them fleeing from war zones such as Syria, Afghanistan, and Iraq. Many people reach the EU after perilous journeys over land or by sea. They mostly first arrive in Greece or in Italy and then try to reach other EU countries in Northern Europe (e.g., Sweden or Germany), passing through other EU member states such as Hungary, Slovenia, and Croatia on the way. In 2015 and in 2016, the number of asylum applications within the EU-28 was approximately 1.3 million (Eurostat, 2017).

This huge flow of migrants has caused tension among EU member states about asylum-seeker relocations, particularly because the number of asylum applications is not equally allocated across 
EU countries. In 2015, five member states (Germany, Hungary, Sweden, Austria, and Italy) registered 75 percent of all asylum applications (Sabbati, 2016). Another critical issue pertains to the transit countries. Typically overwhelmed by the ongoing stream of arrivals and the commensurate strain of providing basic humanitarian assistance, these countries have been requesting EU assistance. The restoration of internal border controls among EU countries, thus limiting freedom of movement across the Schengen Area countries, has been one of the most striking effects of the tension that has arisen among member states because of this mass movement of people. ${ }^{1}$

The ICCS 2016 European regional questionnaire included a set of eight items investigating students' attitudes toward cooperation among European countries. This question sought to capture students' views on the adoption of common policies in Europe (e.g., environmental policies) or on cooperation in specific areas (e.g., strategies to reduce unemployment and to address economic crises).

More specifically, the question asked students to "strongly agree," "agree," "disagree," or "strongly disagree" with the following statements: (a) "European countries should cooperate to protect the environment (e.g. through programs to limit pollution, programs to combat climate change);" (b) "European countries should cooperate to guarantee high levels of employment;" (c) "European countries should cooperate to strengthen their economies;" (d) "European countries should recognize all educational qualifications achieved in any other European country;" (e) "European countries should have a European army for peacekeeping missions;" (f) "European countries should cooperate to prevent and combat terrorism;" (g) "European countries should cooperate to combat illegal entry from non-European countries;" and (h) "European countries should cooperate to provide shelter to people escaping persecution in their countries for reasons of race, religion, or political opinions."

The subsequent eight-item scale had a satisfactory average reliability (Cronbach's alpha $=0.79$ for the combined international dataset), with the positive scale scores reflecting more positive attitudes toward cooperation between European countries (see the item map in Figure 4.1, Appendix C).

Nearly all of the surveyed students favored cooperation among European countries. Across these countries, the average percentages agreeing with the statements ranged from 84 percent (European countries should have a European army for peacekeeping missions) to 98 percent (European countries should cooperate to protect the environment). There was therefore little variation in the extent of agreement with the statements, as is also evident from the European ICCS average percentages in Table 4.1.

Table 4.1 also records the national averages for participating countries on this scale (i.e., students' attitudes toward cooperation among European countries). The highest average score that we recorded was for Croatia with 54 score points.

When we examined the association of students' views on cooperation among European countries with students' gender, students' background (student from an immigrant family versus student from a non-immigrant family), and civic knowledge, we found only a few substantial differences in terms of gender and immigrant status (see Table 4.2). Males were significantly less positive than females in Belgium (Flemish), Denmark, the Netherlands, and Sweden, while students from non-immigrant families in Denmark, Estonia, Italy, and Latvia held more positive attitudes toward cooperation than their immigrant peers did. Sweden was the only country in which students from an immigrant family scored higher than students from a non-immigrant family on the cooperation scale (two points higher on average).

1 We need to stress that the European regional questionnaire was developed before the mass movement of refugees. Recent growth in the numbers of refugees in many European countries was not reflected in the development of the ICCS 2016 study, and the European regional student questionnaire addressed this topic in one item only. However, the mass movement of refugees was a relevant issue at the time the European regional questionnaire was administered and may have influenced students' answers. 


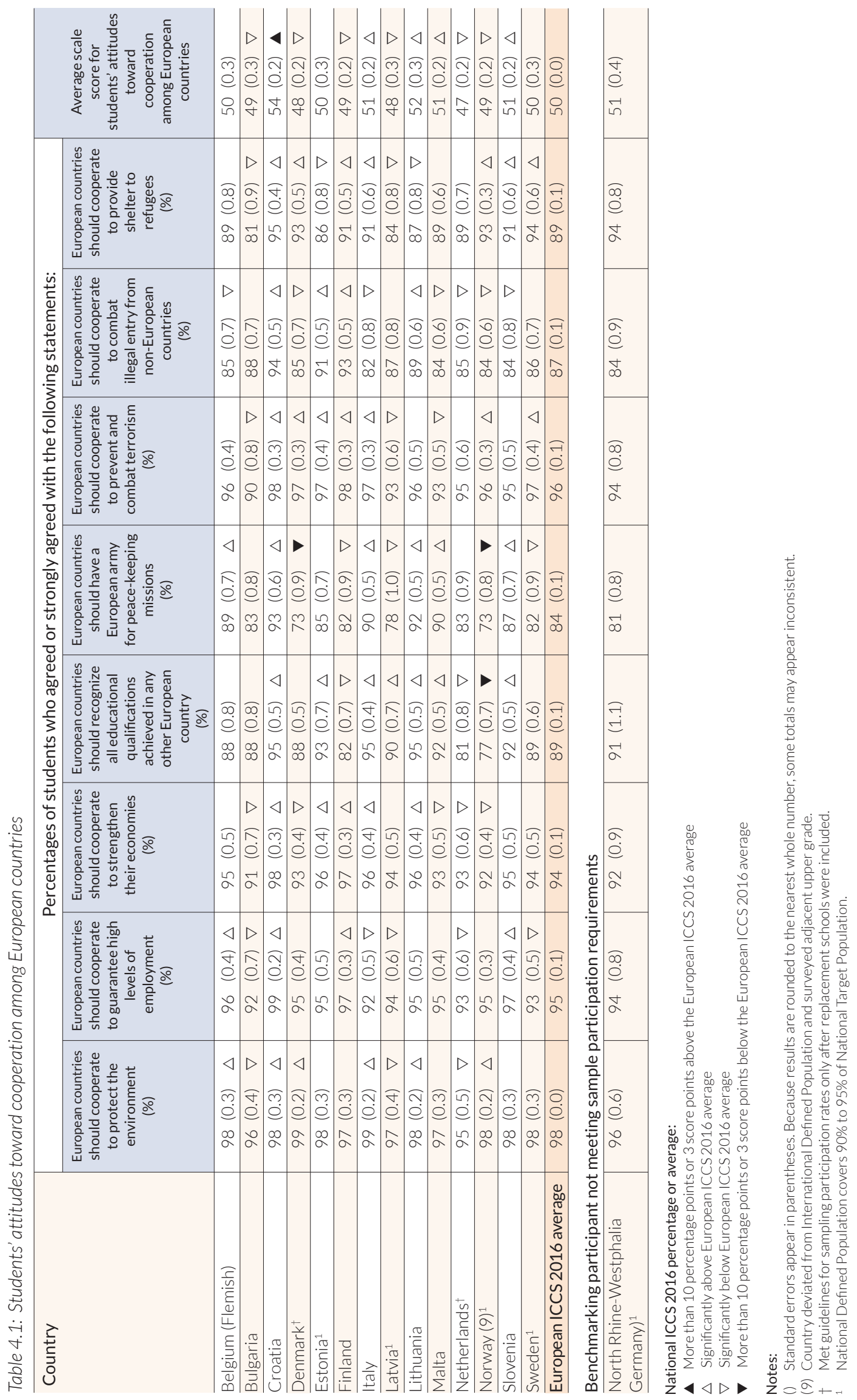




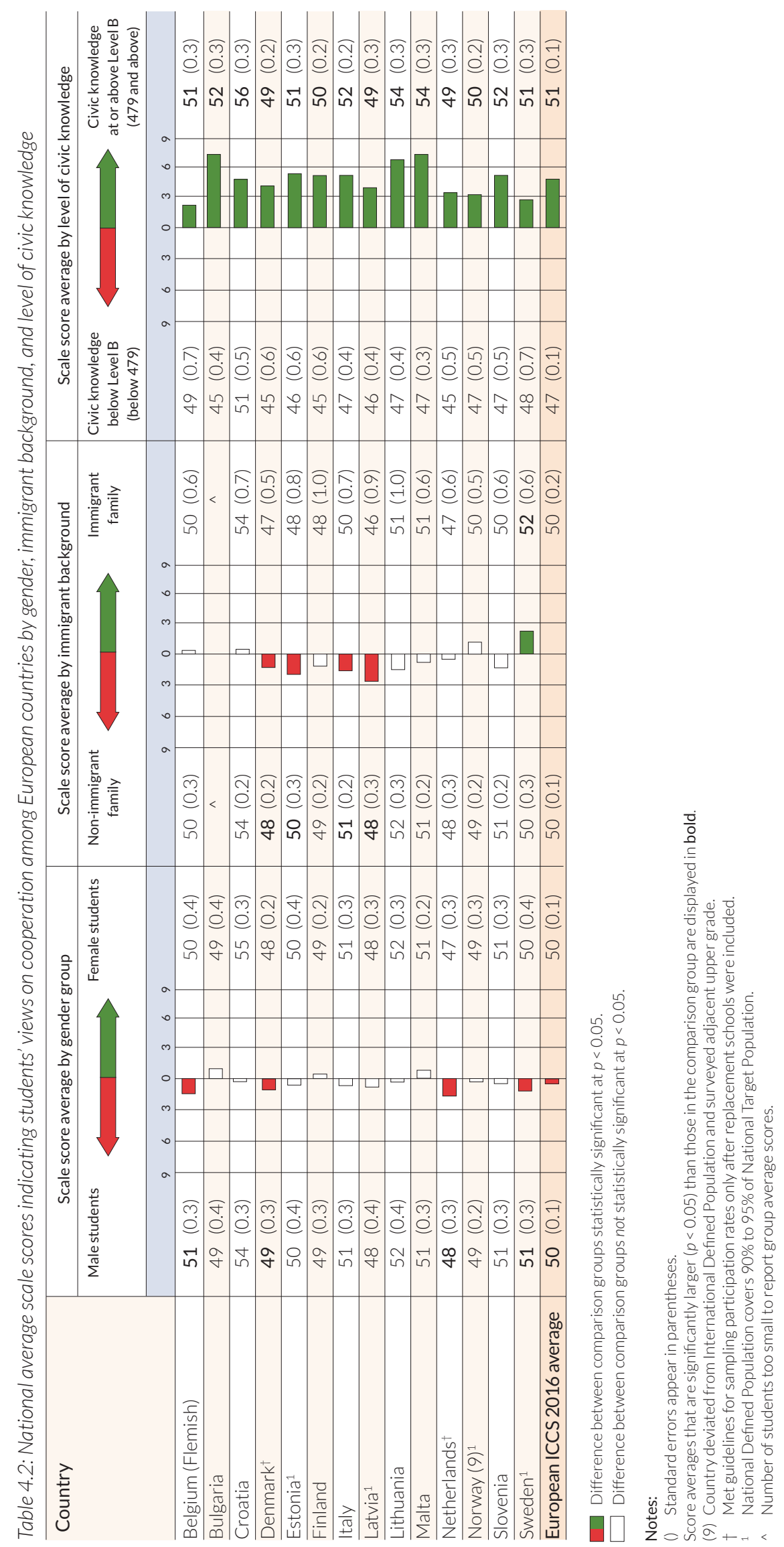


In all countries, the students with a higher level of civic knowledge were the students who expressed the more positive views on adoption of common policies and on cooperation among European countries. On average, the statistically significant difference between students with higher and lower levels of civic knowledge was four scale points.

\section{Students' perceptions of Europe's future}

The ICCS 2016 European regional questionnaire included a question that sought to capture how students imagine Europe's future might be with respect to potential problems and developments in Europe. The question asked students if they thought the following positive scenarios (items a, b, $\mathrm{f}, \mathrm{h}$ ) and negative scenarios (items c, d, e, g) were likely to happen in Europe in the future (response categories of "very likely," "likely," "unlikely," "very unlikely"): (a) "There will be stronger cooperation among European countries;" (b) "There will be greater peace across Europe;" (c) "Terrorism will be more of a threat all across Europe;" (d) "Europe will be more influenced by non-European powers like China, India, and the United States;" (e) "The economy will be weaker in all European countries;" $(\mathrm{f})$ "There will be less air and water pollution in Europe;" (g) "There will be a rise in poverty and unemployment in Europe;" and (h) "Democracy will be strengthened across Europe."

The resultant scales had average reliabilities (Cronbach's alpha $=0.64$ for students' positive expectations for Europe's future, and 0.62 for students' negative expectations for Europe's future) for the pooled ICCS sample with equally weighted countries (see the item maps in Figures 4.2 and 4.3, Appendix C).

The percentages of students expressing positive expectations ranged from 86 percent (cooperation will strengthen among European countries) to 47 percent (air and water pollution will lessen in Europe); see Table 4.3. ${ }^{2}$ Denmark, Finland, Italy, Lithuania, the Netherlands, and Norway recorded percentages significantly above the European ICCS 2016 average in relation to students' expectation that cooperation among European countries would be stronger in the future.

On average across the ICCS 2016 European countries, 64 percent of students thought that the future would see greater peace across Europe. The highest national percentages of agreement were evident in Italy; Denmark, Finland, Malta, the Netherlands, and Sweden recorded percentages significantly above the European ICCS 2016 average. In Slovenia, students' positive perceptions toward greater peace across Europe were more than 10 points below the European ICCS 2016 average. Countries with percentages significantly below the ICCS average included Bulgaria, Croatia, Latvia, Lithuania, and Norway.

Across the European ICCS 2016 countries, only half of the students believed Europe would be less polluted in the future (average agreement: $47 \%$ ). The highest national percentage of students holding this belief (more than 10 points above the European ICCS 2016 average) that we recorded was for Denmark; the lowest such percentage (10 points below the European ICCS 2016 average) was for Croatia. Bulgaria, Finland, Malta, the Netherlands, and Norway showed percentages significantly above the European ICCS 2016 average.

Seventy-eight percent of students on average felt that democracy would be strengthened across Europe. The students in Denmark were the most positive in this regard; the students in Bulgaria the least. Table 4.3 also shows the national average scale scores indicating students' positive expectations with regard to Europe's future. We observed scale scores significantly above the European ICCS 2016 average in Denmark, Finland, Italy, Malta, the Netherlands, and Sweden.

2 Findings from the Standard Eurobarometer 86 survey (European Commission, 2016b) showed that half of the respondents were optimistic about the future of the EU. Among the students participating in the European ICCS 2016 survey, those in Lithuania and Malta were the most optimistic about Europe's future, while those in Italy and Sweden were the least optimistic. 
Table 4.3: Students' positive expectations regarding the future of Europe

\begin{tabular}{|c|c|c|c|c|c|c|c|c|c|c|}
\hline \multirow{3}{*}{$\begin{array}{l}\text { Country } \\
\text { Belgium (Flemish) }\end{array}$} & \multicolumn{8}{|c|}{$\begin{array}{l}\text { Percentages of students who expected that the following positive scenarios } \\
\text { may likely or very likely happen in Europe: }\end{array}$} & & \\
\hline & \multirow{2}{*}{\multicolumn{2}{|c|}{$\begin{array}{c}\text { There will be } \\
\text { stronger } \\
\text { cooperation among } \\
\text { European } \\
\text { countries } \\
(\%)\end{array}$}} & \multicolumn{2}{|c|}{$\begin{array}{c}\text { There will be } \\
\text { greater peace } \\
\text { across Europe } \\
\text { (\%) }\end{array}$} & \multicolumn{2}{|c|}{$\begin{array}{l}\text { There will be } \\
\text { less air and water } \\
\text { pollution in } \\
\text { Europe } \\
\text { (\%) }\end{array}$} & \multicolumn{2}{|c|}{$\begin{array}{l}\text { Democracy will be } \\
\text { strengthened } \\
\text { across Europe } \\
(\%)\end{array}$} & \multicolumn{2}{|c|}{$\begin{array}{l}\text { Average scale } \\
\text { scores for } \\
\text { students reporting } \\
\text { on positive } \\
\text { expectations of the } \\
\text { future of Europe }\end{array}$} \\
\hline & & & $64(1.2)$ & & $43(1.1)$ & $\nabla$ & $79(0.9)$ & & $49(0.2)$ & $\nabla$ \\
\hline Bulgaria & $80(1.1)$ & $\nabla$ & 59 (1.3) & $\nabla$ & $50(1.1)$ & $\triangle$ & $64(1.1)$ & $\nabla$ & $49(0.3)$ & $\nabla$ \\
\hline Croatia & $80(1.0)$ & $\nabla$ & $61(1.1)$ & $\nabla$ & $34(1.0)$ & $\boldsymbol{\nabla}$ & $71(1.0)$ & $\nabla$ & $49(0.2)$ & $\nabla$ \\
\hline Denmark $^{\dagger}$ & $92(0.5)$ & $\triangle$ & $71(1.1)$ & $\triangle$ & $57(0.8)$ & $\Delta$ & $88(0.6)$ & $\Delta$ & $51(0.2)$ & $\triangle$ \\
\hline Estonia $^{1}$ & $87(0.8)$ & & $62(1.2)$ & & 42 (1.3) & $\nabla$ & $76(0.8)$ & & $49(0.3)$ & $\nabla$ \\
\hline Finland & $91(0.6)$ & $\triangle$ & $67(1.2)$ & $\triangle$ & $52(1.1)$ & $\triangle$ & $84(0.6)$ & $\triangle$ & $51(0.2)$ & $\triangle$ \\
\hline Italy & $88(0.5)$ & $\triangle$ & $76(0.8)$ & $\Delta$ & 47 (1.0) & & $79(0.8)$ & & $50(0.2)$ & $\triangle$ \\
\hline Latvia $^{1}$ & $85(0.7)$ & $\nabla$ & $57(1.3)$ & $\nabla$ & $47(1.1)$ & & $73(1.0)$ & $\nabla$ & $49(0.3)$ & $\nabla$ \\
\hline Lithuania & $90(0.6)$ & $\triangle$ & $59(1.1)$ & $\nabla$ & 41 (1.0) & $\nabla$ & $78(0.8)$ & & $50(0.3)$ & \\
\hline Malta & $87(0.5)$ & & $69(0.8)$ & $\triangle$ & $52(0.9)$ & $\triangle$ & $81(0.6)$ & $\triangle$ & $53(0.2)$ & $\triangle$ \\
\hline Netherlands $^{\dagger}$ & $89(0.6)$ & $\triangle$ & $73(1.2)$ & $\triangle$ & $52(1.2)$ & $\triangle$ & $79(0.8)$ & & $51(0.3)$ & $\triangle$ \\
\hline Norway (9) ${ }^{1}$ & $90(0.5)$ & $\triangle$ & $62(0.7)$ & $\nabla$ & $50(0.8)$ & $\triangle$ & $82(0.7)$ & $\triangle$ & $50(0.1)$ & \\
\hline Slovenia & $79(0.9)$ & $\nabla$ & 49 (1.2) & $\nabla$ & $40(1.0)$ & $\nabla$ & $74(1.1)$ & $\nabla$ & $48(0.3)$ & $\nabla$ \\
\hline Sweden $^{1}$ & $86(0.8)$ & & $67(1.0)$ & $\triangle$ & $48(1.0)$ & & $82(0.9)$ & $\triangle$ & $51(0.2)$ & $\triangle$ \\
\hline European ICCS 2016 average & $86(0.2)$ & & $64(0.3)$ & & $47(0.3)$ & & $78(0.2)$ & & $50(0.1)$ & \\
\hline \multicolumn{11}{|c|}{ Benchmarking participant not meeting sample participation requirements } \\
\hline $\begin{array}{l}\text { North-Rhine-Westphalia } \\
{\text { (Germany })^{1}}^{1}\end{array}$ & $74(1.5)$ & & $52(1.7)$ & & $43(1.5)$ & & $75(1.3)$ & & $48(0.4)$ & \\
\hline
\end{tabular}

National ICCS 2016 percentage or average:

A More than 10 percentage points or 3 score points above European ICCS 2016 average

$\triangle$ Significantly above European ICCS 2016 average

$\nabla$ Significantly below European ICCS 2016 average

v More than 10 percentage points or 3 score points below European ICCS 2016 average

Notes:

() Standard errors appear in parentheses. Because results are rounded to the nearest whole number, some totals may appear inconsistent.

(9) Country deviated from International Defined Population and surveyed adjacent upper grade.

† Met guidelines for sampling participation rates only after replacement schools were included.

National Defined Population covers $90 \%$ to $95 \%$ of National Target Population.

The percentages of students holding this negative expectation varied markedly across the countries, with the range extending from 68 percent (Terrorism will be more of a threat all across Europe) to 43 percent (The economy will weaken in all European countries). The students who were most likely to anticipate an increase in terrorism were those in Belgium (Flemish), Italy, Malta, and Slovenia (Table 4.4).

About 67 percent of students anticipated that non-European powers would have an increased influence on Europe. We recorded percentages that were more than 10 points above the European ICCS 2016 average in Denmark and more than 10 points below in Bulgaria and Croatia.

On average, 43 percent of surveyed students believed that the economy would weaken in all European countries; 52 percent envisaged a rise in poverty and unemployment in Europe (Italy and Slovenia recorded percentages more than 10 points above the European ICCS average for this statement). Of the participating countries, Denmark recorded the lowest percentages of agreement 
Table 4.4: Students' negative expectations regarding the future of Europe

\begin{tabular}{|c|c|c|c|c|c|c|c|c|c|c|}
\hline \multirow{3}{*}{$\begin{array}{l}\text { Country } \\
\text { Belgium (Flemish) }\end{array}$} & \multicolumn{8}{|c|}{$\begin{array}{c}\text { Percentages of students who expected that the following negative scenarios } \\
\text { may likely or very likely happen in Europe: }\end{array}$} & & \\
\hline & \multicolumn{2}{|c|}{$\begin{array}{c}\text { Terrorism will be } \\
\text { more of a threat } \\
\text { all across } \\
\text { Europe } \\
(\%)\end{array}$} & \multicolumn{2}{|c|}{$\begin{array}{c}\text { Europe will be } \\
\text { more influenced } \\
\text { by non-European } \\
\text { powers like China, } \\
\text { India, and } \\
\text { the United States } \\
\text { (\%) }\end{array}$} & \multicolumn{2}{|c|}{$\begin{array}{c}\text { The economy } \\
\text { will be weaker } \\
\text { in all European } \\
\text { countries } \\
(\%)\end{array}$} & \multicolumn{2}{|c|}{$\begin{array}{c}\text { There will be } \\
\text { a rise in poverty } \\
\text { and unemployment } \\
\text { in Europe } \\
(\%)\end{array}$} & \multicolumn{2}{|c|}{$\begin{array}{l}\text { Average scale } \\
\text { scores for student } \\
\text { disagreement } \\
\text { with negative } \\
\text { expectations of the } \\
\text { future of Europe }\end{array}$} \\
\hline & $73(1.0)$ & $\triangle$ & $67(1.3)$ & & $43(1.3)$ & & $55(1.2)$ & $\triangle$ & $49(0.2)$ & $\nabla$ \\
\hline Bulgaria & $62(1.2)$ & $\nabla$ & $57(1.1)$ & $\nabla$ & $46(1.1)$ & $\triangle$ & $59(1.2)$ & $\triangle$ & $51(0.3)$ & $\triangle$ \\
\hline Croatia & 69 (1.1) & & $50(1.2)$ & $\nabla$ & $39(1.0)$ & $\nabla$ & $53(1.1)$ & & $51(0.3)$ & $\triangle$ \\
\hline Denmark $^{\dagger}$ & $68(0.8)$ & & $79(0.9)$ & $\Delta$ & $30(0.8)$ & $\nabla$ & $36(0.9)$ & $\boldsymbol{\nabla}$ & $52(0.1)$ & $\triangle$ \\
\hline Estonia $^{1}$ & $67(1.1)$ & & $69(1.1)$ & & $42(0.9)$ & & $49(0.9)$ & $\nabla$ & $50(0.2)$ & \\
\hline Finland & $67(1.1)$ & & $69(0.9)$ & $\triangle$ & $45(0.9)$ & $\triangle$ & $47(0.9)$ & $\nabla$ & $50(0.2)$ & $\Delta$ \\
\hline Italy & $77(0.8)$ & $\triangle$ & $77(0.8)$ & $\triangle$ & $52(1.1)$ & $\triangle$ & $64(0.9)$ & $\Delta$ & $47(0.2)$ & $\nabla$ \\
\hline Latvia $^{1}$ & $63(0.9)$ & $\nabla$ & $66(1.2)$ & & $44(1.1)$ & & $52(1.0)$ & & $51(0.2)$ & $\triangle$ \\
\hline Lithuania & $61(1.0)$ & $\nabla$ & $69(1.1)$ & & $38(1.3)$ & $\nabla$ & $44(1.0)$ & $\nabla$ & $52(0.2)$ & $\triangle$ \\
\hline Malta & $77(0.7)$ & $\triangle$ & $65(0.8)$ & $\nabla$ & $50(0.9)$ & $\triangle$ & $59(0.8)$ & $\triangle$ & $48(0.2)$ & $\nabla$ \\
\hline Netherlands $^{\dagger}$ & $68(1.2)$ & & $64(1.2)$ & $\nabla$ & $37(1.5)$ & $\nabla$ & $43(1.2)$ & $\nabla$ & $51(0.3)$ & $\triangle$ \\
\hline${\text { Norway }(9)^{1}}^{1}$ & $63(0.7)$ & $\nabla$ & $69(0.7)$ & $\triangle$ & $49(0.6)$ & $\triangle$ & $57(0.7)$ & $\triangle$ & $50(0.1)$ & \\
\hline Slovenia & 75 (1.1) & $\triangle$ & $73(0.9)$ & $\triangle$ & $50(1.1)$ & $\triangle$ & $67(1.0)$ & $\Delta$ & $47(0.2)$ & $\nabla$ \\
\hline Sweden $^{1}$ & $60(1.1)$ & $\nabla$ & $71(0.9)$ & $\triangle$ & $37(1.0)$ & $\nabla$ & $49(1.2)$ & $\nabla$ & $51(0.2)$ & $\triangle$ \\
\hline European ICCS 2016 average & $68(0.3)$ & & $67(0.3)$ & & $43(0.3)$ & & $52(0.3)$ & & $50(0.1)$ & \\
\hline \multicolumn{11}{|c|}{ Benchmarking participant not meeting sample participation requirements } \\
\hline $\begin{array}{l}\text { North-Rhine-Westphalia } \\
{\text { (Germany })^{1}}\end{array}$ & $75(1.1)$ & & $54(1.6)$ & & $43(2.0)$ & & $52(1.6)$ & & $50(0.3)$ & \\
\hline
\end{tabular}

National ICCS 2016 percentage or average:

A More than 10 percentage points or 3 score points above European ICCS 2016 average

$\triangle$ Significantly above European ICCS 2016 average

$\nabla$ Significantly below European ICCS 2016 average

$\boldsymbol{\nabla}$ More than 10 percentage points or 3 score points below European ICCS 2016 average

Notes:

() Standard errors appear in parentheses. Because results are rounded to the nearest whole number, some totals may appear inconsistent.

(9) Country deviated from International Defined Population and surveyed adjacent upper grade.

t Met guidelines for sampling participation rates only after replacement schools were included.

National Defined Population covers $90 \%$ to $95 \%$ of National Target Population.

with these statements (more than 10 percentage points below the European ICCS 2016 average).

Table 4.4 also shows the national average scale scores for students' disagreement with statements indicating negative expectations of Europe's future. The average scale scores for students in Bulgaria, Croatia, Denmark, Finland, Latvia, Lithuania, the Netherlands, and Sweden were all significantly above the European ICCS 2016 average.

The ICCS 2016 international student questionnaire asked students how concerned they felt about potential threats to the world's future (e.g., pollution, global financial crisis, violent conflict, climate change, unemployment, terrorism). Some of these aspects align with the topics included in the items in the European ICCS 2016 student questionnaire that sought to record students' positive and negative expectations with respect to Europe in the future. The students from the European countries considered pollution and terrorism to be main threats to the world's future, but deemed crime, violent conflict, financial crises, and unemployment as less serious. ${ }^{3}$

3 For further details, see Chapter 5 of the ICCS 2016 international report (Schulz, Ainley, Fraillon, Losito, Agrusti, \& Friedman, 2018). 


\section{Students' perceptions of the European Union}

According to the Standard Eurobarometer 86 survey (European Commission, 2016a), peace, human rights, and democracy are the values that best represent the European Union. The ICCS 2009 European regional survey found that the level of support for enlarging the EU varied across participating countries. In addition, on average across the ICCS 2009 countries, majorities of students wanted to see greater harmonization of policies in Europe (Kerr, Sturman, Schulz, \& Burge, 2010).

The ICCS 2016 European regional questionnaire asked students about their perceptions of the European Union. The question included a set of five items that together covered a large variety of topics, from politics to the economy, from the environment to human rights. The question asked students to what extent they agreed ("strongly agree," "agree," "disagree," "strongly disagree") with each of these five statements about the EU: (a) "<EU> guarantees respect for human rights all over Europe;" (b) "<EU> makes Europe a safe place to live;" (c) < EU> takes care of the environment;" (d) "<EU > is good for the economy of individual countries;" and (e) "<EU > is good because countries share a common set of rules and laws."

The scale that we derived from these items had average reliability (Cronbach's alpha $=0.80$ ) for the combined international dataset. The higher scores on the scale indicate more positive perceptions of the EU (see the item map in Figure 4.4, Appendix C).

As illustrated in Table 4.5, most of the surveyed students were positive about the European Union: on average, 88 percent of them agreed that the EU safeguards human rights and that the EU is good because it allows countries to share a common set of rules and laws. The only country to record a percentage more than 10 points below the European ICCS 2016 average for this item was Latvia. A large majority of students (European ICCS 2016 average: 85\%) agreed that the EU makes Europe a safe place to live. The average percentage of agreement for this item in Slovenia, however, was more than 10 points below the European ICCS 2016 average. Most students (82\%) also agreed that the EU is good for the economy (although, again, the percentage in Latvia was more than 10 points below the European ICCS 2016 average). Seventy-seven percent of students agreed that the EU takes care of the environment. However, the percentage agreeing with this statement was more than 10 points below the European ICCS 2016 average in Belgium (Flemish).

Table 4.5 also shows national average scale scores indicating students' attitudes toward the EU. The highest national averages that we recorded were those for Croatia, Lithuania, and Malta (percentages significantly above the European ICCS 2016 average). The lowest national averages that we observed were those in Belgium (Flemish), Denmark, Latvia, Norway, Slovenia, and Sweden.

The ICCS 2016 student questionnaire included a set of questions related to students' trust in civic institutions, groups, and sources of information and to students' intentions to participate in elections once they reached adulthood ("expected electoral participation"). Both questions encompassed specific options for students from European countries, namely students' trust in the European Commission and in the European Parliament, and students' expected participation in European elections.

Most of the surveyed students expressed quite a lot or complete trust in the European Commission and in the European Parliament (Table 4.6). The majority of students trusted the European Commission (European ICCS 2016 average: 70\%) and the European Parliament (European ICCS 2016 average: 72\%), with Finland, Italy, Lithuania, and Sweden showing percentages significantly above the European ICCS 2016 average for both items. Countries with percentages significantly below the European ICCS 2016 average for both items included Bulgaria, Croatia, Estonia, Latvia, and Slovenia. 


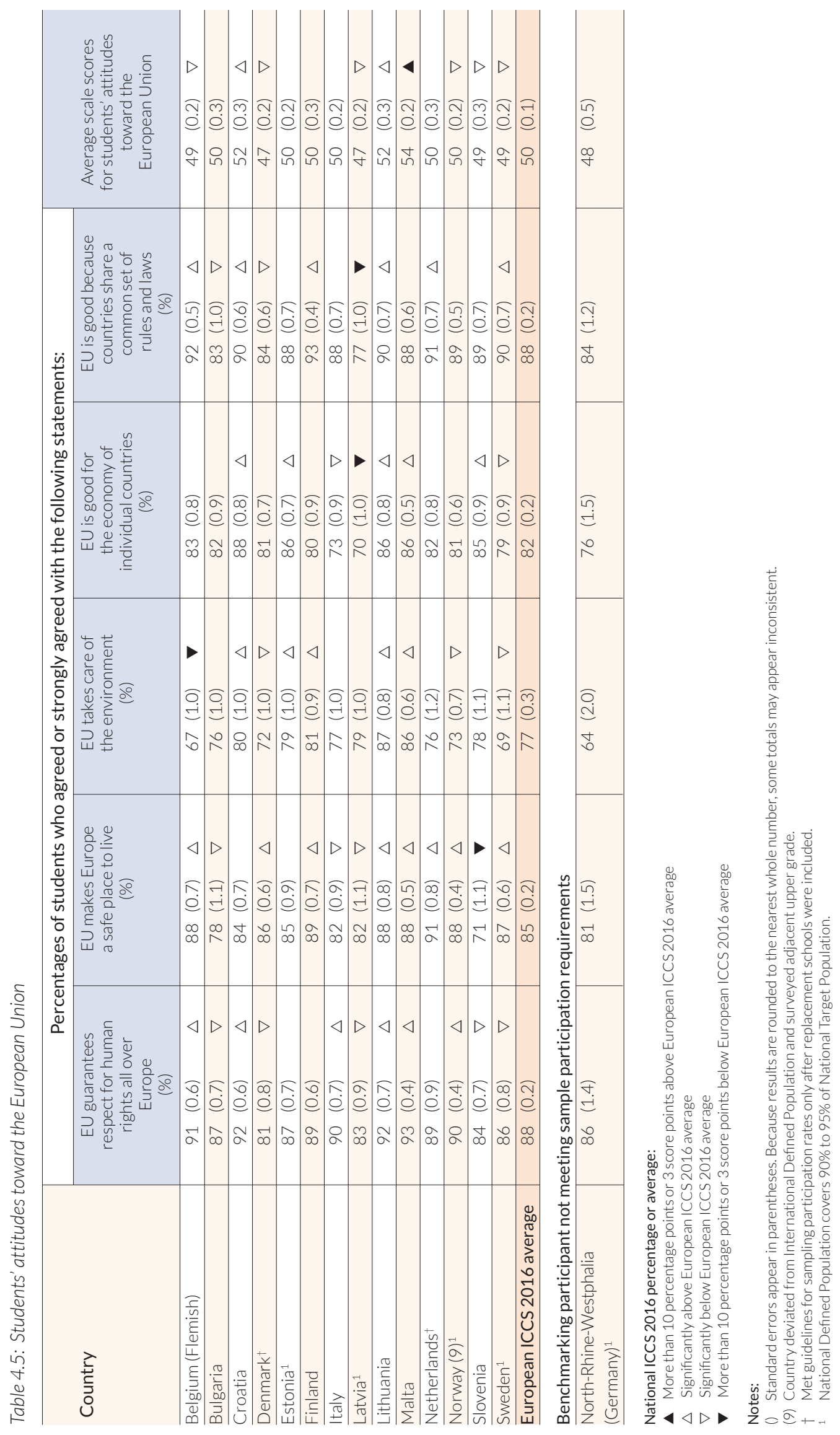




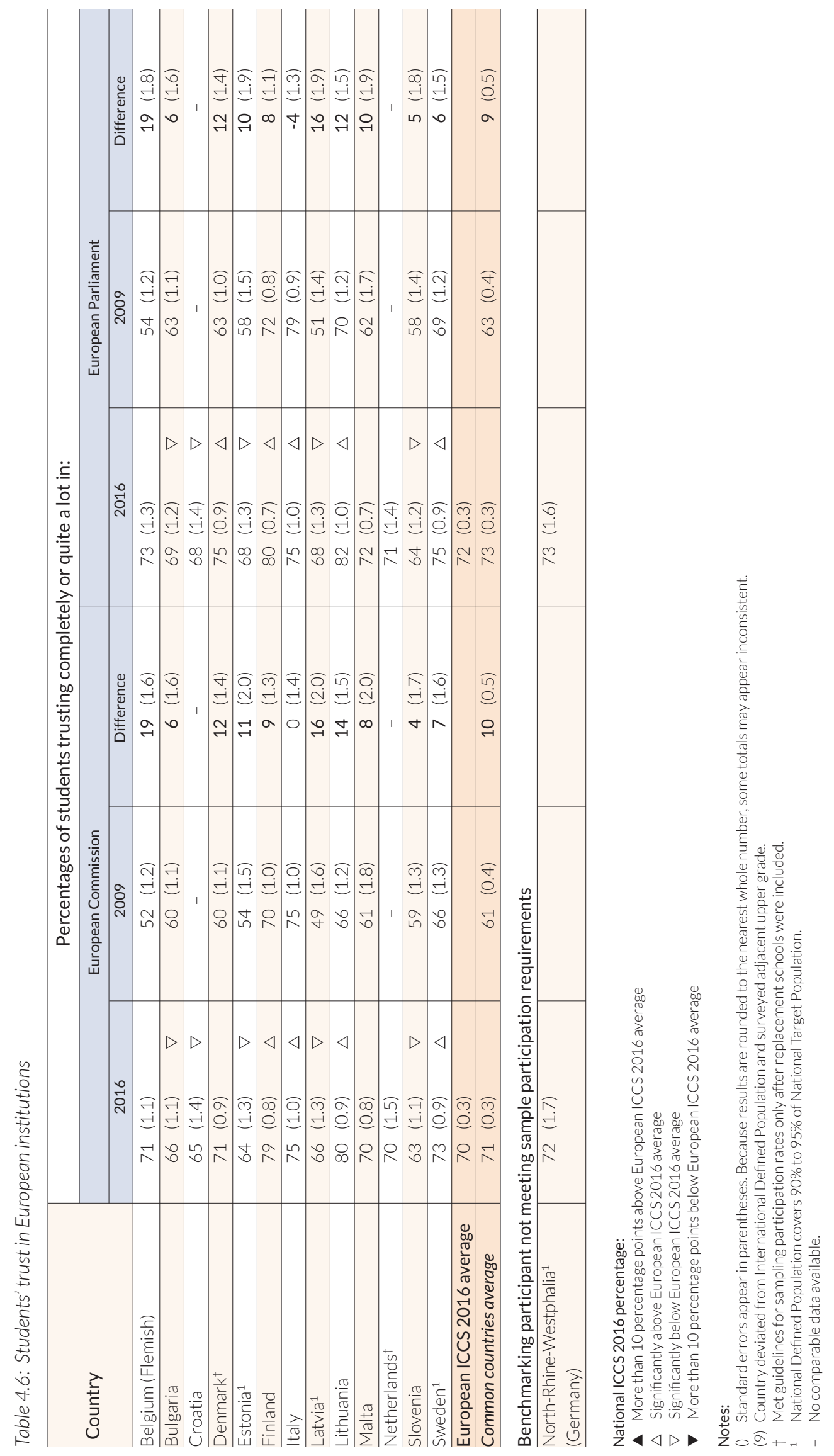


In comparison with their ICCS 2009 counterparts, the ICCS 2016 students expressed greater trust, on average, in the European Commission and in the European Parliament. The differences over that time period were 10 and nine points respectively. Italy was the only country to show no difference between cycles in relation to trust in the European Commission. However, Italy also recorded a four-point decrease over time for trust in the European Parliament.

The national percentages of students who reported that they would certainly or probably vote in local, national, and European elections in the future were, on average, lower for European elections (European ICCS 2016 average: 65\%) than for local and national ones (European ICCS 2016 average: 85\%) (see Table 4.7). Countries where the percentages of students expecting to vote in European elections were more than 10 percentage points above the European ICCS 2016 average included Croatia, Denmark, Italy, and Sweden. The lowest such percentages were evident in Estonia and in Slovenia.

Students' expectations of participating in elections increased between ICCS 2009 and ICCS 2016. The highest increase that we recorded was for expected participation in European elections.

\section{Students' perceptions of their life in the future}

In 2015 the youth unemployment rate reached 19.7 percent in Europe, reflecting young people's difficulties in finding a job (Eurostat, 2017). The Standard Eurobarometer 86 survey (European Commission, 2016a) included a question asking respondents if their quality of life "was better before." Majorities of respondents in 21 member states agreed with this statement. Among the European countries participating in ICCS 2016, Italy and Croatia recorded the highest percentages of agreement. Sweden, Finland, and the Netherlands, however, recorded the highest percentages of disagreement.

In the opinion survey conducted for the 2014 European Youth Event (EYE 2014), more than half of the respondents thought that the financial crisis had marginalized and excluded young people from economic and social life in their countries. Among the ICCS 2016 European countries, the highest percentage of young people holding this view was recorded in Croatia; the lowest percentage was reported in Denmark (European Parliament, 2014).

The ICCS 2016 European regional questionnaire contained a question asking students about their expectations in relation to different aspects of their future, namely their job, salary, and cultural opportunities. Students were asked how well the following statements reflected their expectations of their life in the future (response categories of "very likely," "likely," "unlikely," "very unlikely"): (a) "I will find a steady job;" (b) "My financial situation will be better than that of my parents;" (c) "I will find a job I like;" (d) "I will have the opportunity to travel abroad for leisure;" and (e) "I will earn enough money to start a family." The resultant scale had a good average reliability (Cronbach's alpha $=0.80$ for the pooled international sample), with the positive scale scores reflecting more optimistic expectations (see the item map in Figure 4.5, Appendix C).

The lower-secondary students surveyed during ICCS 2016 expressed mainly positive attitudes about their respective futures (Table 4.8). We observed little variation in the extent of optimism across the countries for each of the items. Majorities of students felt that they would very likely or likely find a steady job (European ICCS 2016 average: 95\%), find a job they liked (European ICCS 2016 average: 91\%), and earn enough money to start a family (European ICCS 2016 average: 96\%). On average, 89 percent of students believed that they would have the opportunity to travel abroad for leisure. Only one country recorded low percentages-Croatia.

We did, however, record slightly lower percentages and more variation across countries with respect to students thinking their financial situation would probably be securer than that of their parents. On average, about 78 percent of the respondents held this view. However, the corresponding national percentages in Belgium (Flemish) and Sweden were more than 10 points below the European ICCS 2016 average. 


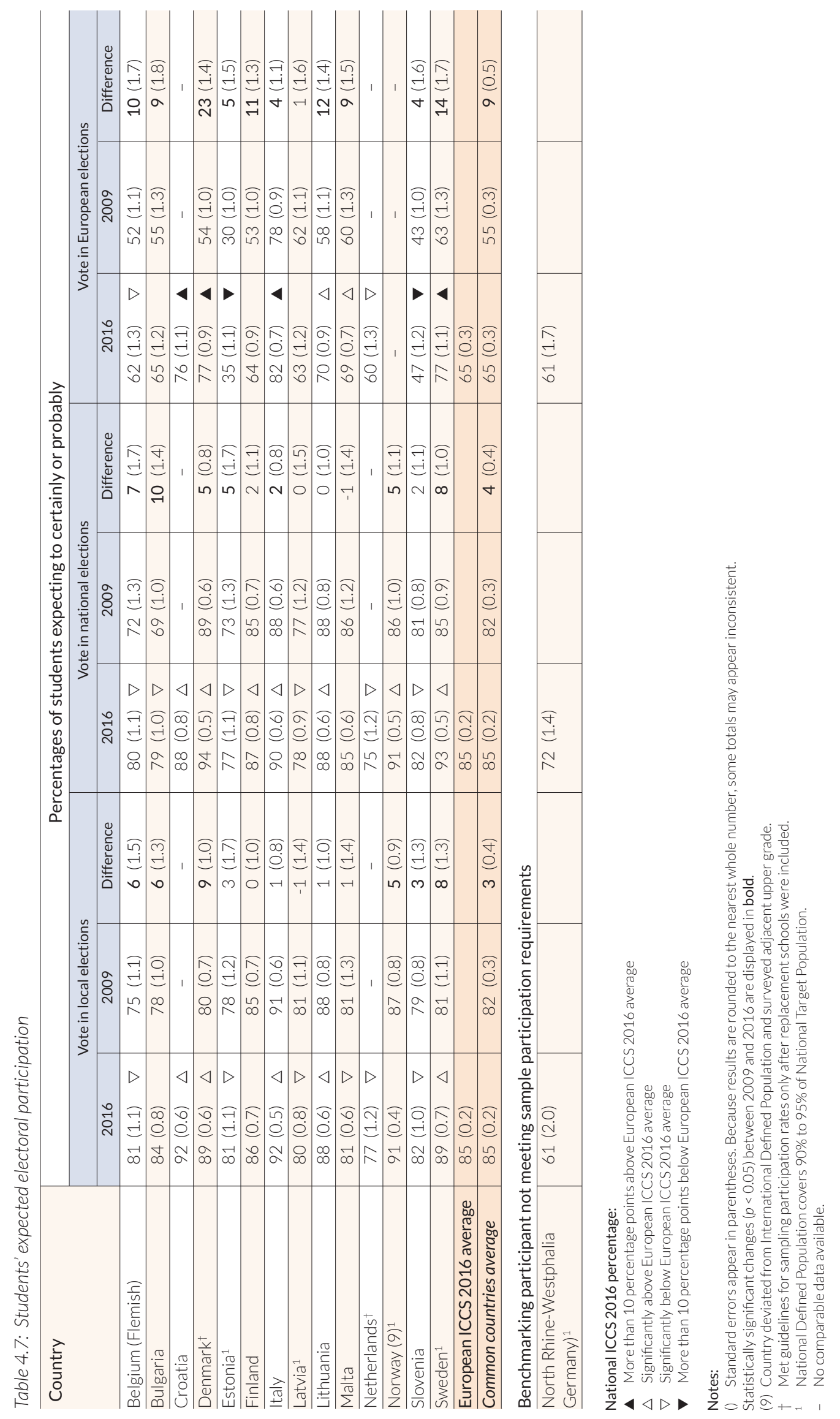


Table 4.8: Students' expectations for their individual future

\begin{tabular}{|c|c|c|c|c|c|c|c|c|c|}
\hline \multirow{3}{*}{$\begin{array}{l}\text { Country } \\
\text { Belgium (Flemish) }\end{array}$} & \multicolumn{9}{|c|}{ Percentages of students who expected that the following may likely or very likely happen: } \\
\hline & \multicolumn{2}{|c|}{$\begin{array}{l}\text { I will find a } \\
\text { steady job } \\
(\%)\end{array}$} & \multicolumn{2}{|c|}{$\begin{array}{c}\text { My financial } \\
\text { situation will be } \\
\text { better than that } \\
\text { of my parents } \\
\text { (\%) }\end{array}$} & \multicolumn{2}{|c|}{$\begin{array}{l}\text { I will find a } \\
\text { job I like } \\
\text { (\%) }\end{array}$} & $\begin{array}{l}\text { I will have the } \\
\text { opportunity to } \\
\text { travel abroad } \\
\text { for leisure } \\
\text { (\%) }\end{array}$ & \multicolumn{2}{|c|}{$\begin{array}{c}\text { I will earn } \\
\text { enough money to } \\
\text { start a family } \\
(\%)\end{array}$} \\
\hline & $98(0.3)$ & $\triangle$ & $68(1.1)$ & $\mathbf{\nabla}$ & $94(0.5)$ & $\triangle$ & $96(0.5) \triangle$ & $98(0.3)$ & $\triangle$ \\
\hline Bulgaria & $92(0.6)$ & $\nabla$ & $84(0.8)$ & $\triangle$ & $86(0.9)$ & $\nabla$ & $81(1.0) \quad \nabla$ & $90(0.9)$ & $\nabla$ \\
\hline Croatia & $90(0.7)$ & $\nabla$ & $76(1.0)$ & $\nabla$ & $84(0.9)$ & $\nabla$ & $74(1.1) \quad \nabla$ & $94(0.4)$ & $\nabla$ \\
\hline Denmark $^{\dagger}$ & $98(0.2)$ & $\triangle$ & $84(0.6)$ & $\triangle$ & $98(0.2)$ & $\triangle$ & $97(0.3) \triangle$ & $98(0.2)$ & $\triangle$ \\
\hline Estonia $^{1}$ & $95(0.5)$ & & $84(0.8)$ & $\triangle$ & $93(0.5)$ & $\triangle$ & $89(0.8)$ & $95(0.4)$ & \\
\hline Finland & $97(0.3)$ & $\triangle$ & $76(0.9)$ & $\nabla$ & $94(0.4)$ & $\triangle$ & $93(0.5) \triangle$ & $96(0.4)$ & \\
\hline Italy & $92(0.5)$ & $\nabla$ & $81(0.8)$ & $\triangle$ & $89(0.5)$ & $\nabla$ & $79(0.8) \quad \nabla$ & $95(0.6)$ & \\
\hline Latvia $^{1}$ & $96(0.5)$ & & $87(0.8)$ & $\triangle$ & $90(0.6)$ & & $89(0.6)$ & $95(0.4)$ & \\
\hline Lithuania & $97(0.4)$ & $\triangle$ & $86(0.7)$ & $\triangle$ & $91(0.6)$ & & $90(0.7)$ & $97(0.4)$ & $\triangle$ \\
\hline Malta & $93(0.4)$ & $\nabla$ & $85(0.6)$ & $\triangle$ & $89(0.5)$ & $\nabla$ & $88(0.7)$ & $92(0.5)$ & $\nabla$ \\
\hline Netherlands $^{\dagger}$ & $97(0.3)$ & $\triangle$ & $71(1.2)$ & $\nabla$ & $96(0.5)$ & $\triangle$ & $96(0.5) \triangle$ & $98(0.4)$ & $\triangle$ \\
\hline Norway (9) ${ }^{1}$ & $98(0.2)$ & $\triangle$ & $75(0.7)$ & $\nabla$ & $97(0.3)$ & $\triangle$ & $96(0.3) \triangle$ & $97(0.3)$ & $\triangle$ \\
\hline Slovenia & $92(0.6)$ & $\nabla$ & $71(1.1)$ & $\nabla$ & $88(0.7)$ & $\nabla$ & $80(0.9) \quad \nabla$ & $95(0.5)$ & \\
\hline Sweden $^{1}$ & $96(0.4)$ & & $68(1.2)$ & $\nabla$ & 89 (1.0) & $\nabla$ & $92(0.5) \triangle$ & $96(0.4)$ & \\
\hline European ICCS 2016 average & $95(0.1)$ & & $78(0.2)$ & & $91(0.2)$ & & $89(0.2)$ & $96(0.1)$ & \\
\hline \multicolumn{10}{|c|}{ Benchmarking participant not meeting sample participation requirements } \\
\hline $\begin{array}{l}\text { North-Rhine-Westphalia } \\
\left(\text { Germany) }{ }^{1}\right.\end{array}$ & $97(0.6)$ & & $74(1.7)$ & & $94(1.0)$ & & $87(0.9)$ & $96(0.7)$ & \\
\hline
\end{tabular}

National ICCS 2016 percentage:

A More than 10 percentage points above European ICCS 2016 average

$\triangle$ Significantly above European ICCS 2016 average

$\nabla$ Significantly below European ICCS 2016 average

- More than 10 percentage points below European ICCS 2016 average

Notes:

() Standard errors appear in parentheses. Because results are rounded to the nearest whole number, some totals may appear inconsistent.

(9) Country deviated from International Defined Population and surveyed adjacent upper grade.

† Met guidelines for sampling participation rates only after replacement schools were included.

National Defined Population covers $90 \%$ to $95 \%$ of National Target Population. 


\section{References}

European Commission. (2016a). Standard Eurobarometer 86 "European citizenship" report. Brussels, Belgium: Author. Retrieved from http://ec.europa.eu/COMMFrontOffice/publicopinion/index.cfm/Survey/ getSurveyDetail/instruments/STANDARD/surveyKy/2137

European Commission. (2016b). Standard Eurobarometer 86 "Public opinion in the European Union, first results." Brussels, Belgium: Author. Retrieved from http://ec.europa.eu/COMMFrontOffice/publicopinion/index. cfm/Survey/getSurveyDetail/instruments/STANDARD/surveyKy/2137

European Parliament. (2014). Flash Eurobarometer of the European Parliament (EP EB395): European youth in 2014. Brussels, Belgium: Author. Retrieved from http://www.europarl.europa.eu/pdf/eurobarometre/2014/ youth/eb_395_synthesis_youth_en.pdf

Eurostat. (2017). Migration and migrant population statistics. Eurostat statistics explained [Website]. Retrieved from http://ec.europa.eu/eurostat/statistics-explained/index.php/migration_and_migrant_ population_statistics

Kerr, D., Sturman, L., Schulz, W., \& Burge, B. (2010). ICCS 2009 European report: Civic knowledge, attitudes and engagement among lower secondary school students in twenty-four European countries. Amsterdam, the Netherlands: International Association for the Evaluation of Educational Achievement (IEA).

Sabbati, G. (2016). Recent migration flows to the EU (European Parliamentary Research Service PE 580.893). Retrieved from http://www.europarl.eruopa.eu/RegData/etudes/ATAG/2017/595918/EPRS_ ATA\%282017\%29595918_EN.pdf

Schulz, W., Ainley, J., Fraillon, J., Losito, B., \& Agrusti, G. (2016). IEA International Civic and Citizenship Education Study 2016: Assessment framework. Cham, Switzerland: Springer.

Schulz, W., Ainley, J., Fraillon, J., Losito, B., Agrusti, G., \& Friedman, T. (2018). Becoming citizens in a changing world: IEA International Civic and Citizenship Education Study 2016 international report. Cham, Switzerland: Springer.

Open Access This chapter is licensed under the terms of the Creative Commons Attribution-NonCommercial 4.0 International License (http://creativecommons.org/licenses/by-nc/4.0/), which permits any noncommercial use, sharing, adaptation, distribution and reproduction in any medium or format, as long as you give appropriate credit to the original author(s) and the source, provide a link to the Creative Commons license and indicate if changes were made.

The images or other third party material in this chapter are included in the chapter's Creative Commons license, unless indicated otherwise in a credit line to the material. If material is not included in the chapter's Creative Commons license and your intended use is not permitted by statutory regulation or exceeds the permitted use, you will need to obtain permission directly from the copyright holder. 


\title{
CHAPTER 5:
}

\section{Main findings and implications for policy and practice}

\begin{abstract}
Within its overarching purpose of investigating the ways in which young people are prepared to undertake their roles as citizens in a range of countries and through its questionnaire for students in participating European countries, the International Civic and Citizenship Education Study 2016 (ICCS 2016) addressed issues related to the specific European context and to the problems currently facing Europe. Decreased solidarity together with the increase in populist, nationalist, anti-establishment political parties in several European countries are the factors complicating dynamics linked not only to the original project of European integration but also to the economic and political relationships between countries (Archick, 2017). Furthermore, in recent years, public debate in Europe has been characterized by broad questions relating to citizens' sense of belonging to Europe, the need for stronger cooperation among European countries, and concerns about immigration and the effects of the financial crisis.
\end{abstract}

In addition to demographic changes, European countries are facing comprehensive and intertwined problems such as pollution and economic crisis. The rising demand for democratic participation is often connected to a sense that the established governance procedures are proving inadequate (Hennette, Piketty, Sacriste, \& Vauchez, 2017). These issues explain why the European ICCS 2016 research team paid special attention to migration and to freedom of movement within Europe, and viewed these matters against a background encompassing perspectives focused on increasing integration and cooperation among European countries and on the wider milieu of the financial crisis. Within this context, the European student questionnaire also explored students' attitudes toward Europe and the extent to which students felt they belonged to it, as well as their perceptions of Europe's likely future.

This chapter summarizes the main findings from the ICCS 2016 European student questionnaire with regards to students' perceptions of their being European and their opportunities to learn about Europe at school. It also summarizes the findings on students' attitudes toward freedom and restriction of movement and immigration in Europe, and to students' perceptions of Europe and the future of Europe.

\section{Summary of main findings}

Most surveyed students saw themselves as Europeans, and their sense of European identity increased in the interval between ICCS 2009 and ICCS 2016.

Majorities of students saw themselves as European and were proud to live in Europe. Students from countries that are members of the European Union also expressed pride that their country was a member of the EU.

When students were asked about the opportunities they had to learn about Europe at school, high percentages of them reported that the history of Europe was the most common such opportunity. The national percentages of students who said they had opportunities to learn about political and economic systems at the European level, about political and social issues in European countries, and about political and economic integration varied across the participating European countries. 


\section{Surveyed students favored freedom for European citizens to reside and work within Europe}

Large majorities of students strongly agreed or agreed with statements related to freedom of movement for European citizens within Europe and tended to strongly disagree or disagree with statements on restricting movement. However, strong variation was evident across countries for the statements related to restricting of movement, with students of some countries tending to favor such restrictions. In all countries, students' positive views on freedom of movement appeared to be associated with higher levels of civic knowledge. Students with a higher level of civic knowledge also tended not to endorse restrictions on European citizens' freedom of movement within Europe.

Although we observed little variation in students' endorsement of statements on the freedom of movement by gender and by immigrant background, we did find strong differences with regard to restriction of movement by gender groups. Here, male students were more in favor of restriction than their female peers were.

\section{Surveyed students held positive attitudes toward equal rights for immigrants}

Majorities of surveyed students favored providing immigrants with the same opportunities for education and the same rights as everyone else in the country. Some variation was evident, however, in the extent to which students favored more specific rights for immigrants, such as immigrants having the right to speak their own language, to vote in elections, and to continue their own lifestyles.

Female students and students from an immigrant family tended to hold more positive attitudes than males and students from a non-immigrant family (findings also observed in ICCS 2009). In almost all countries, students' positive attitudes toward immigrants were associated with higher levels of civic knowledge (at or above Level B on the civic knowledge scale). In several countries, as evident from comparison of the European findings in ICCS 2009 and ICCS 2016, students' positive attitudes toward immigrants remained relatively unchanged over that time period.

\section{Surveyed students supported cooperation among European countries with regard to the adoption of common policies in Europe}

On average, most students agreed with the need for European countries to work together to adopt common policies on environmental protection, economic development, strengthening employment opportunities, and combating terrorism. Most students also endorsed common policies focused on providing refugees with shelter and preventing illegal immigration. Students with a higher level of civic knowledge showed greater support for cooperation among European countries than their peers with lower levels of knowledge did.

\section{Students generally felt positive about Europe's future but expressed concern about some issues}

Although students expressed confidence that cooperation among European countries would increase and that democracy and peace would strengthen across Europe, almost half of them saw economic downturn and increases in poverty, unemployment, and pollution as potential problematic issues. They also identified terrorism and the influence of non-European powers as major threats to the future stability of Europe.

\section{Students tended to hold positive perceptions of the European Union}

Most surveyed students were positive about the role of the EU in guaranteeing respect for human rights, keeping people in Europe safe, protecting the environment, strengthening the economy, and sharing common rules and laws. Across the European ICCS 2016 participating countries, majorities of students trusted the European Commission and the European Parliament. Students also said that they thought they would be more likely, on average, to participate in local and national elections than in European elections. 


\section{Students were generally positive about their own lives in the future}

Overall, the surveyed students expressed optimism about their respective futures. Majorities of students felt confident that they would find a steady job, find a job they liked, would earn enough money to start a family, and would travel abroad for leisure.

\section{Implications for policy and practice}

Any discussion of potential implications for policy and practice requires careful consideration of the limitations associated with the features of ICCS 2016 in general and the European student questionnaire in particular. The cross-sectional survey design of this study means that we cannot establish firm causal relationships based on its results. Also, several of Europe's largest countries did not participate in ICCS 2016 and in the European regional option. Consequently, we cannot generalize beyond the scope of this data collection because it is not fully representative of the countries in Europe. Despite these restrictions, the data have produced several interesting results that suggest possible policy implications for the future.

The first such finding was the association between students' perceptions of their European identity and their trust in civic institutions. The more students trusted their national civic institutions, the more likely they were to see themselves as part of a broader community at the supranational level. These findings suggest that national and European identities can positively coexist.

The findings regarding students' opportunities to learn about civics and citizenship at school showed variation across countries. Most of the students across the ICCS 2016 European countries said they had learned about the history of Europe at school. However, the extent to which they had opportunities to learn about economic systems at the European level, about political and social issues in European countries, and about political and economic integration between European countries varied across the countries. These findings not only support the results of previous studies on the national curricula of European countries but also indicate that schools can do more to enhance students' knowledge about European topics and issues.

The role of schools in developing students' civic knowledge perhaps assumes even greater importance given the associations between students' level of civic knowledge (as measured in ICCS 2016) and students' positive attitudes toward equal rights for immigrants and toward freedom of movement within Europe. Despite the variation we observed across countries, students with higher levels of civic knowledge tended to be the students expressing more tolerant attitudes. They were also more in favor than their less knowledgeable peers of cooperation among European countries.

As pointed out in the international ICCS 2016 report (Schulz, Ainley, Fraillon, Losito, Agrusti, \& Friedman, 2018), many countries globally continue to express concern about young people's participation in political elections. The national percentages of European ICCS 2016 students who said they would certainly or probably vote in European elections were lower than the national percentages of students who said they would certainly or probably vote in national and local elections. The ICCS 2016 results also indicated associations between civic knowledge, civic engagement, and students' expectation to vote. The inclusion of EU-related topics in national curricula and the development of initiatives supporting students' engagement at school and in the community may strengthen students' awareness of the importance of their participation as citizens at a supranational level. 


\section{Outlook}

The ICCS 2016 European report has provided a rich database that provides a platform for future research on civic and citizenship education in Europe. Together with the international results of ICCS 2016, the European data offer researchers and other interested parties the opportunity not only to conduct more in-depth secondary analyses involving interpretation of the collected data at different levels and from different perspectives but also to address international and regionspecific aspects of civic and citizenship education.

Since the drafting and the administration of the ICCS 2016 European regional student questionnaire, Europe has experienced mass movements of refugees to this region, the rise of populism (in several countries), and potential threats to democracy, such as more vociferous racism and the increase in terrorist attacks. These developments provide new challenges for civic and citizenship education in Europe, especially in terms of helping countries address these emerging issues and of sustaining the long-term aims (e.g., social cohesion, integration) of this learning area. The next cycle of ICCS, scheduled for 2022, will attempt to address these new developments as well as changes in policy agendas directed at ensuring civic and citizenship education is an important area of school and out-of-school education.

\section{References}

Archick, K. (2017, February 27). The European Union: Current challenges and future prospects. Washington DC: Congressional Research Service (US). Retrieved from https://fas.org/sgp/crs/row/R44249.pdf

Hennette, S., Piketty, T., Sacriste, G., \& Vauchez, A. (2017). Pour un traité de démocratisation de l'Europe [For a treaty democratizing Europe]. Paris, France: Ed. du Seuil.

Schulz, W., Ainley, J., Fraillon, J., G., Losito, B., Agrusti, G., \& Friedman, T. (2018). Becoming citizens in a changing world: IEA International Civic and Citizenship Education Study 2016 international report. Cham, Switzerland: Springer.

Open Access This chapter is licensed under the terms of the Creative Commons Attribution-NonCommercial 4.0 International License (http://creativecommons.org/licenses/by-nc/4.0/), which permits any noncommercial use, sharing, adaptation, distribution and reproduction in any medium or format, as long as you give appropriate credit to the original author(s) and the source, provide a link to the Creative Commons license and indicate if changes were made.

The images or other third party material in this chapter are included in the chapter's Creative Commons license, unless indicated otherwise in a credit line to the material. If material is not included in the chapter's Creative Commons license and your intended use is not permitted by statutory regulation or exceeds the permitted use, you will need to obtain permission directly from the copyright holder. 


\section{APPENDIX A: SAMPLING INFORMATION AND PARTICIPATION \\ RATES}

Table A.1: Coverage of ICCS 2016 target population

\begin{tabular}{|c|c|c|c|c|}
\hline \multirow[t]{2}{*}{ Country } & \multirow{2}{*}{$\begin{array}{c}\text { International target population } \\
\text { Coverage } \\
(\%)\end{array}$} & \multicolumn{3}{|c|}{ Exclusions from target population } \\
\hline & & $\begin{array}{l}\text { School-level } \\
\text { exclusions } \\
(\%)\end{array}$ & $\begin{array}{l}\text { Within-sample } \\
\text { exclusions } \\
(\%)\end{array}$ & $\begin{array}{l}\text { Overall exclusions } \\
\text { (\%) }\end{array}$ \\
\hline Belgium (Flemish) & 100 & 4.8 & 0.1 & 4.9 \\
\hline Bulgaria & 100 & 1.6 & 0.9 & 2.5 \\
\hline Croatia & 100 & 0.5 & 4.6 & 5.2 \\
\hline Denmark & 100 & 1.7 & 2.7 & 4.4 \\
\hline Estonia & 100 & 5.1 & 1.6 & 6.7 \\
\hline Finland & 100 & 2.2 & 1.1 & 3.3 \\
\hline Italy & 100 & 0.8 & 3.9 & 4.8 \\
\hline Latvia & 100 & 4.3 & 2.2 & 6.5 \\
\hline Lithuania & 100 & 3.5 & 1.8 & 5.3 \\
\hline Malta & 100 & 1.6 & 0.2 & 1.8 \\
\hline Netherlands & 100 & 3.0 & 0.9 & 3.9 \\
\hline Norway & 100 & 1.3 & 4.2 & 5.5 \\
\hline Slovenia & 100 & 1.8 & 0.8 & 2.7 \\
\hline Sweden & 100 & 2.2 & 4.3 & 6.4 \\
\hline \multicolumn{5}{|l|}{ Benchmarking participant } \\
\hline $\begin{array}{l}\text { North Rhine-Westphalia } \\
\text { (Germany) }\end{array}$ & 100 & 1.4 & 5.6 & 7.0 \\
\hline
\end{tabular}

Note:

Because results are rounded to the nearest whole number, some totals may appear inconsistent. 


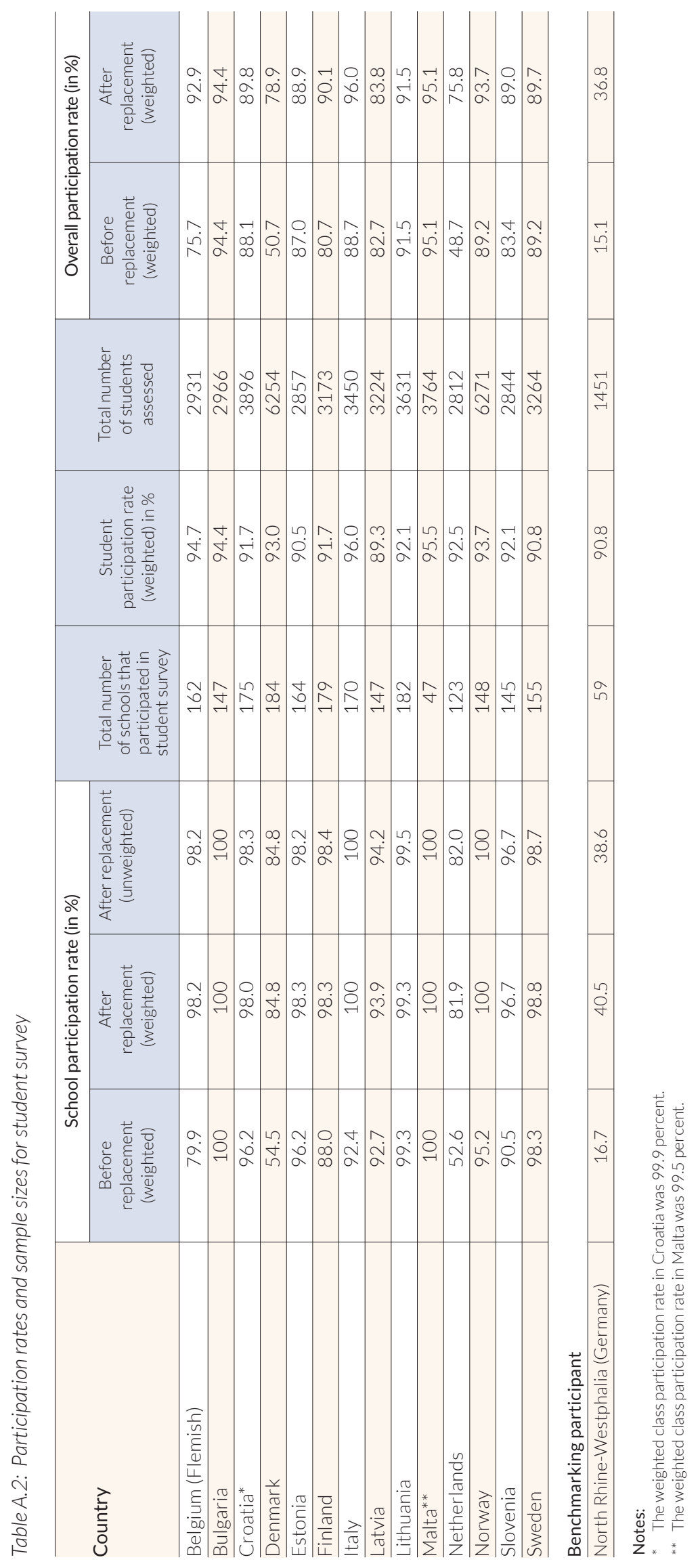




\section{APPENDIX B: STUDENT PERCENTAGES FOR DICHOTOMOUS VARIABLES}

Table B.1: Percentages of students in categories for dichotomous variables

\begin{tabular}{|c|c|c|c|c|c|c|}
\hline \multirow{3}{*}{$\begin{array}{l}\text { Country } \\
\text { Belgium (Flemish) }\end{array}$} & \multicolumn{2}{|c|}{ Gender } & \multicolumn{2}{|c|}{ Immigrant status } & \multicolumn{2}{|c|}{ Levels of civic knowledge } \\
\hline & \multirow{2}{*}{$\begin{array}{l}\text { Males } \\
51 \text { (1.8) } \\
\end{array}$} & \multirow{2}{*}{$\begin{array}{l}\text { Females } \\
49 \text { (1.8) }\end{array}$} & $\begin{array}{c}\text { Students from } \\
\text { immigrant } \\
\text { family }\end{array}$ & $\begin{array}{c}\text { Students from } \\
\text { non-immigrant } \\
\text { family }\end{array}$ & $\begin{array}{l}\text { Civic knowledge } \\
\text { below Level B } \\
\text { (below 479) }\end{array}$ & $\begin{array}{l}\text { Civic knowledge } \\
\text { below Level B } \\
\text { (below 479) }\end{array}$ \\
\hline & & & $16(1.6)$ & $84(1.6)$ & $24(1.8)$ & $76(1.8)$ \\
\hline Bulgaria* & $54(1.8)$ & $46(1.8)$ & $0(0.0)$ & $100 \quad(0.0)$ & $45(2.1)$ & $55(2.1)$ \\
\hline Croatia & $50(0.9)$ & $50(0.9)$ & $9(0.9)$ & $91 \quad(0.9)$ & $24(1.4)$ & $76(1.4)$ \\
\hline Denmark $^{\dagger}$ & $49(0.8)$ & $51(0.8)$ & $9(0.8)$ & $91 \quad(0.8)$ & $13(1.0)$ & $87(1.0)$ \\
\hline Estonia $^{1}$ & $50(1.2)$ & $50(1.2)$ & $9(0.7)$ & $91 \quad(0.7)$ & $20(1.2)$ & $80(1.2)$ \\
\hline Finland & $53(1.1)$ & $47(1.1)$ & $3(0.5)$ & $97 \quad(0.5)$ & $13(0.8)$ & $87(0.8)$ \\
\hline Italy & $52(0.9)$ & $48(0.9)$ & $11(0.9)$ & $89 \quad(0.9)$ & $29(1.2)$ & 71 (1.2) \\
\hline Latvia $^{1}$ & $48(1.3)$ & $52(1.3)$ & $4(0.4)$ & $96 \quad(0.4)$ & $42(1.7)$ & $58(1.7)$ \\
\hline Lithuania & $50(0.8)$ & $50(0.8)$ & $2(0.3)$ & $98 \quad(0.3)$ & $31(1.5)$ & $69(1.5)$ \\
\hline Malta & $51(0.5)$ & $49(0.5)$ & $8(0.4)$ & $92 \quad(0.4)$ & $42(1.3)$ & $58(1.3)$ \\
\hline Netherlands $^{\dagger}$ & $49(1.2)$ & $51(1.2)$ & $9(1.4)$ & $91 \quad(1.4)$ & $32(2.3)$ & $68(2.3)$ \\
\hline Norway $(9)^{1}$ & $50(0.6)$ & $50(0.6)$ & $11(1.1)$ & $89 \quad(1.1)$ & $18(0.8)$ & $82(0.8)$ \\
\hline Slovenia & $52(0.7)$ & $48(0.7)$ & $15(1.0)$ & 85 (1.0) & $25(1.1)$ & $75(1.1)$ \\
\hline Sweden $^{1}$ & $51(1.0)$ & $49(1.0)$ & $18(1.6)$ & 82 (1.6) & $17(1.0)$ & $83(1.0)$ \\
\hline European ICCS 2016 average & $50(0.2)$ & $50(0.2)$ & $9 \quad(0.3)$ & $91 \quad(0.3)$ & $34(0.3)$ & $66(0.3)$ \\
\hline
\end{tabular}

Notes:

() Standard errors appear in parentheses.

(9) Country deviated from International Defined Population and surveyed adjacent upper grade.

Met guidelines for sampling participation rates only after replacement schools were included.

National Defined Population covers $90 \%$ to $95 \%$ of National Target Population.

In the report, data related to immigrant status has not been reported because of the small number of students from immigrant families 


\section{APPENDIX C: ITEM MAPS}

The ICCS 2016 European student questionnaire used sets of items to measure constructs relevant in the field of civic and citizenship education and having region-specific importance and relevance. Usually, sets of Likert-type items with four categories (e.g., "strongly agree," "agree," "disagree," and "strongly disagree"). The items were then recoded so that the higher scale scores reflected more positive attitudes or higher frequencies.

The Rasch Partial Credit Model (Masters \& Wright, 1997) was used for scaling, and the resulting weighted likelihood estimates (Warm, 1989) were transformed into a metric with a mean of 50 and a standard deviation of 10 for equally weighted ICCS 2016 national samples that satisfied guidelines for sample participation. For scales equated to ICCS 2009, the averages and standard deviations were 50 and 10 respectively for all countries that participated in the previous survey. The ICCS 2016 technical report will provide more details on scaling and equating procedures (Schulz, Carstens, Losito, \& Fraillon, forthcoming).

The resulting ICCS 2016 scale scores can be interpreted with regard to the average across countries participating in ICCS 2016 (or ICCS 2009 where scales were equated), but they do not reveal the extent to which students endorsed the items used for measurement. However, our application of the Rasch Partial Credit Model allowed us to map scale scores to item responses, making it possible for us to predict, for each scale score, the most likely item response for a respondent. (For an application of these properties in the previous survey, see Schulz \& Friedman, 2011.)

Appendix C provides item maps for each questionnaire scale presented in the report. The maps provide a prediction of the minimum coded score (e.g., 0 = "strongly disagree," 1 = "disagree" 2 = "agree," and 3 = "strongly agree") a respondent would obtain on a Likert-type item based on their questionnaire scale score. For example, for students with a certain scale score, one could predict that they would have a 50 percent probability of at least agreeing (or strongly agreeing) with a particular item (see example item in Figure C.1). For each item, it is possible to determine Thurstonian thresholds, the points at which a minimum item score becomes more likely than any lower score and which determine the boundaries between item categories on the item map.

This information can also be summarized at the scale level by calculating the average thresholds across all of the corresponding scaled items. For four-point Likert-type scales, we typically did the calculation for the second threshold, thereby allowing us to predict how likely it would be for a respondent with a certain scale score to have (on average across items) responses in the two lower or upper categories. Use of this approach in the case of items measuring agreement made it possible to distinguish between scale scores with which respondents were most likely to agree or disagree with the average item used for scaling.

In some of the reporting tables with national average scale scores, means are depicted as boxes that indicate their mean values plus or minus sampling error. The boxes are set in graphical displays (e.g., Table 2.2 in the main body of the text) that have two underlying colors. National average scores located in the darker-shaded area indicate that, on average across items, students would have had responses in the respective lower item categories (e.g., "agree, disagree or strongly disagree"). National average scores found in the lighter-shaded area indicate that students' average item responses would have been in the upper item response categories (e.g., "strongly agree"). Choice of thresholds between categories depended on the distributions of responses. For example, if over 80 percent of students responded with agreement, this meant a threshold set between "strongly agree" and all other categories. 
Figure C.1: Example of questionnaire item map

Scale scores $($ mean $=50$, standard deviation $=10)$

Item

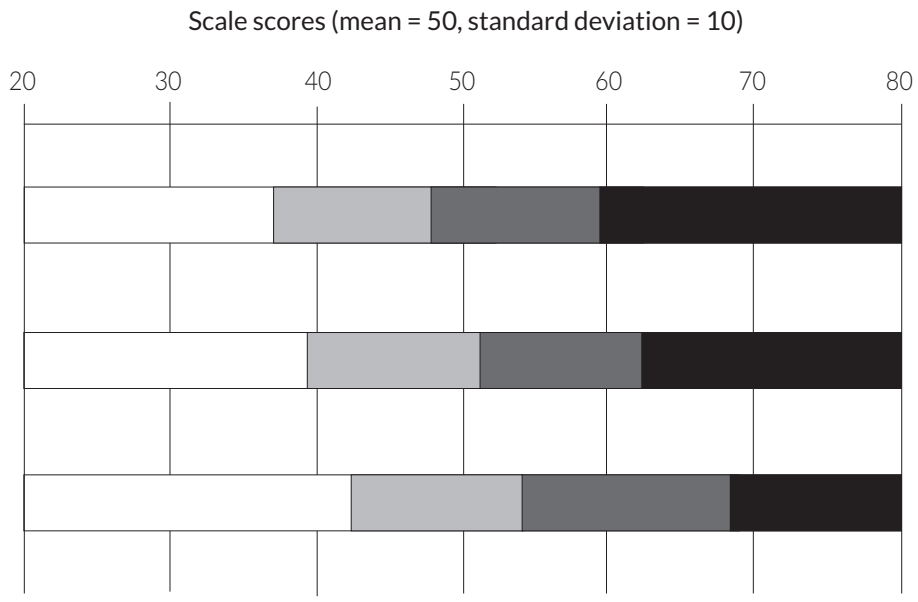

Item \#3

Strongly disagree

Disagree

Agree

Strongly agree

\section{Example of how to interpret the item-by-score map}

\#1: $\quad$ A respondent with score 30 has more than a 50 percent probability of strongly disagreeing with all three items

\#2: A respondent with score 40 has more than a 50 percent probability of not strongly disagreeing with Items 1 and 2 but of strongly disagreeing with Item 3

\#3: A respondent with score 50 has more than a 50 percent probability of agreeing with Item 1 and of disagreeing with Items 2 and 3

\#4: A respondent with score 60 has more than a 50 percent probability of strongly agreeing with Item 1 and of at least agreeing with Items 2 and 3

\#5: A respondent with score 70 has more than a 50 percent probability of strongly agreeing with Items 1, 2, and 3 
Figure 2.1: Item map for the scale reflecting students' sense of European identity

How much do you agree or disagree with the following statements?

I see myself as European

I am proud to live in Europe

\section{I feel part of Europe}

I see myself first as a citizen of Europe and then as a citizen of the world

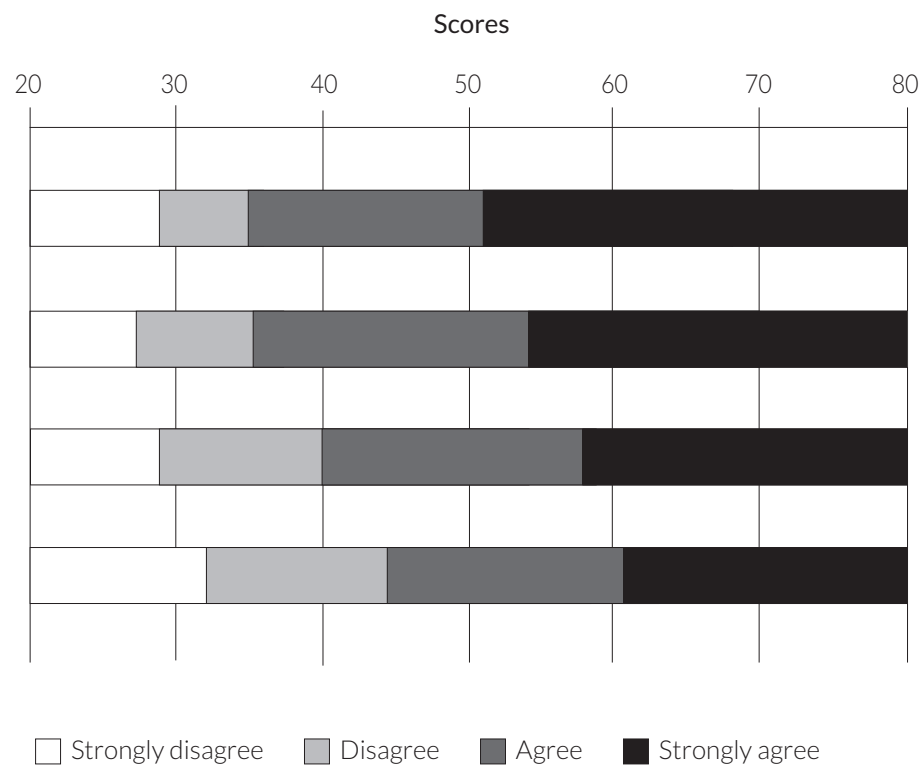

Sum

\begin{tabular}{|l|l|l|l|}
\hline 1 & 4 & 34 & 60 \\
\hline
\end{tabular}

50

40 100 100

\begin{tabular}{|l|l|l|l|}
\hline 4 & 19 & 47 & 31 \\
\hline
\end{tabular}

I see myself first as a citizen of Europe and then as a citizen of the world 
Figure 2.2: Item map for the scale reflecting students' reports on opportunities for learning about Europe at school

At school, to what extent have you had the opportunity to learn about the following issues or topics?

Political and economic systems of other European countries

The history of Europe

Political and social issues in other European countries

Political and economic integration between European countries (for example the European Union)

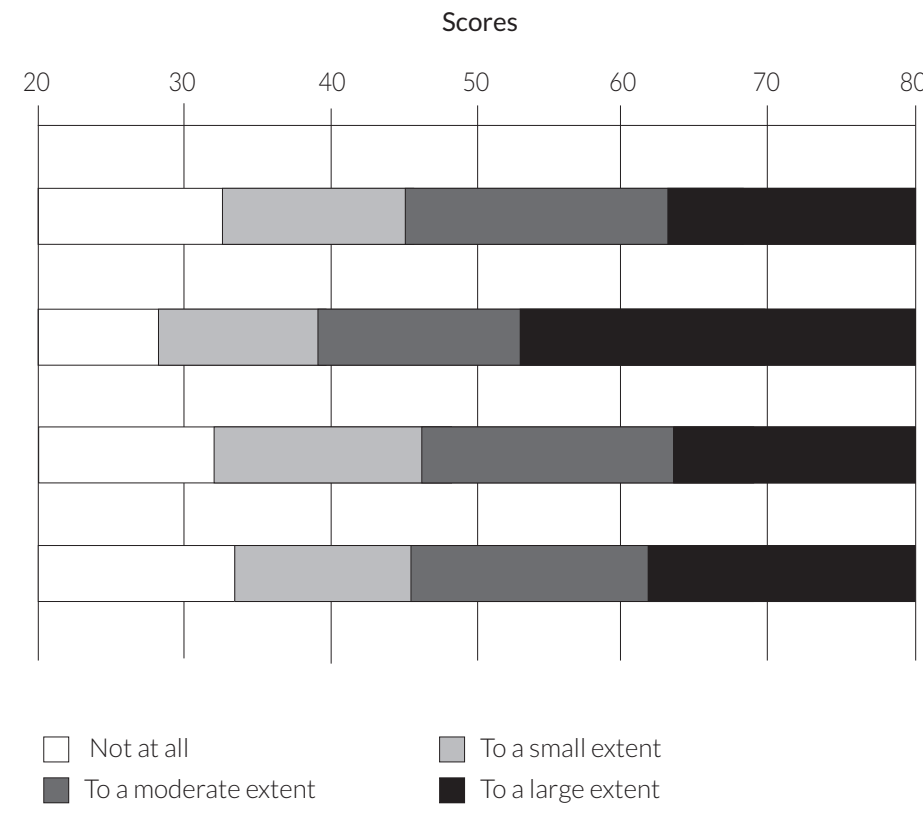

Sum

Political and economic systems of other European countries

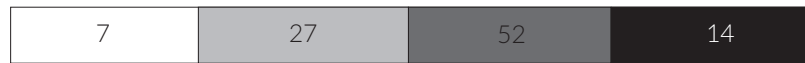

100

The history of Europe

\begin{tabular}{l|l}
\hline 3 & 14
\end{tabular}

43

Political and social issues in other European countries

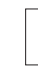

countries (for example the European Union)

\begin{tabular}{|l|l|l|l|}
\hline 6 & 30 & 50 & 14 \\
\hline
\end{tabular}

100

\begin{tabular}{|l|l|l|l|}
\hline 7 & 28 & 48 & 16 \\
\hline
\end{tabular}


Figure 3.1: Item map for the scale reflecting students' attitudes toward freedom of migration within Europe

How much do you agree or disagree with the following statements related to the possibilities for European citizens to work in other European countries?

Allowing citizens of European countries to work anywhere in Europe is good for the European economy

Citizens of European countries should be allowed to work anywhere in Europe

Allowing citizens of European countries to work anywhere in Europe helps to reduce unemployment

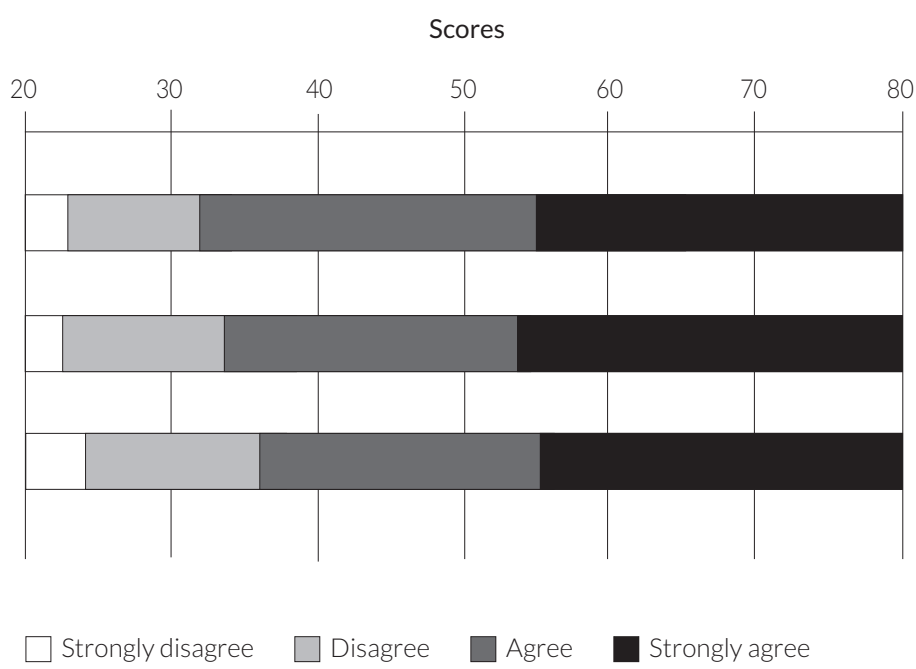

Allowing citizens of European countries to work anywhere in Europe is good for the European economy

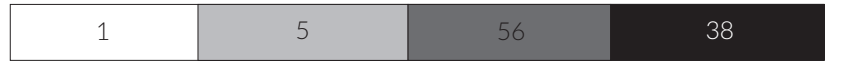

100

Citizens of European countries should be allowed to work anywhere in Europe

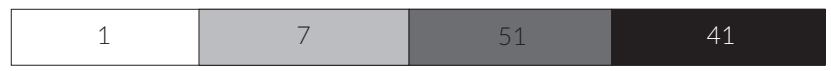

100

Allowing citizens of European countries to work anywhere in Europe helps to reduce unemployment

\begin{tabular}{|l|l|l|}
\hline 1 & 10 & 53 \\
\hline
\end{tabular}

100 
Figure 3.2: Item map for the scale reflecting students' attitudes toward restricting migration within Europe

How much do you agree or disagree with the following statements related to the possibilities for European citizens to work in other European countries?

Citizens of European countries should be allowed to work in another European country only if their skills are needed there

Citizens of European countries who wish to work in another country should be allowed to take only the jobs that no one in the other country wants to do

Only a limited number of people should be allowed to move for work from one European country to another

Citizens of European countries should be allowed to work in another European country only if their skills are needed there

Citizens of European countries who wish to work in another country should be allowed to take only the jobs that no one in the other country wants to do

Only a limited number of people should be allowed to move for work from one European country to another

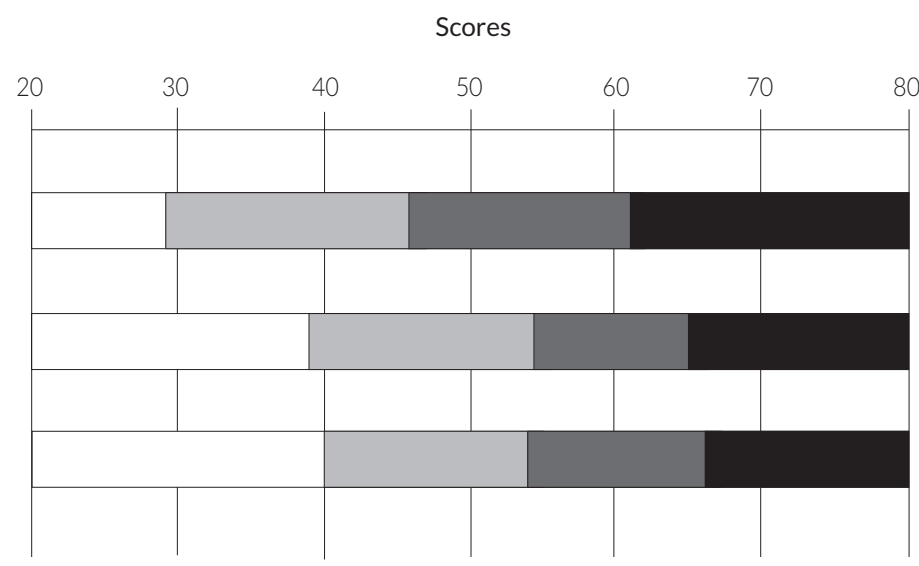

Strongly disagree

Disagree

Agree

Strongly agree

Sum

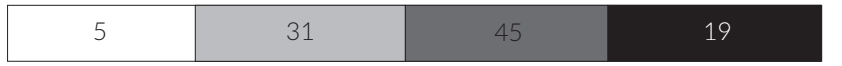

100

\begin{tabular}{|c|c|c|}
\hline 18 & 45 & 27 \\
\hline
\end{tabular}

100

20 43 
Figure 3.3: Item map for the scale reflecting students' attitudes toward equal rights for immigrants

How much do you agree or disagree with the following statements about <immigrants>?

$<$ Immigrants > should have the opportunity to continue speaking their own language

$<$ Immigrant> children should have the same opportunities for education that other children in the country have

$<$ Immigrants $>$ who live in a country for several years should have the opportunity to vote in elections

$<$ Immigrants > should have the opportunity to continue their own customs and lifestyle

$<$ Immigrants $>$ should have the same rights that everyone else in the country has

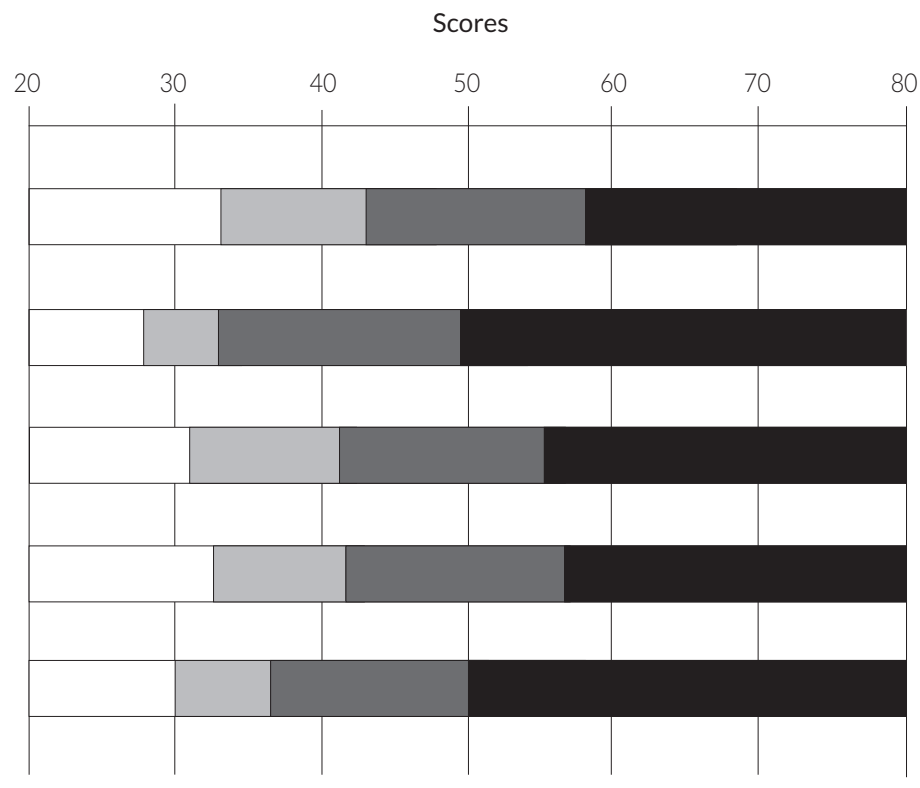

$\square$ Strongly disagree $\square$ Disagree $\quad \square$ Agree $\quad \square$ Strongly agree

$\square$ Strongly disagree $\square$ Disagree $\quad \square$ Agree $\quad \square$ Strongly agree
Sum

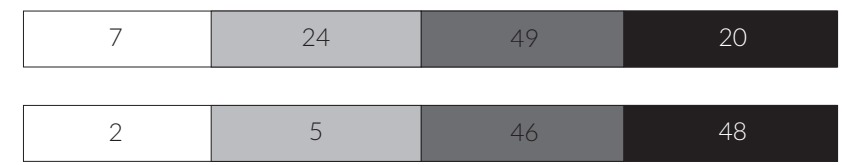
speaking their own language

$<$ Immigrant> children should have the same opportunities for education that other children in the country have

$<$ Immigrants $>$ who live in a country for several years should have the opportunity to vote in elections

< Immigrants > should have the opportunity to continue their own customs and lifestyle

$<$ Immigrants $>$ should have the same rights that everyone else in the country has

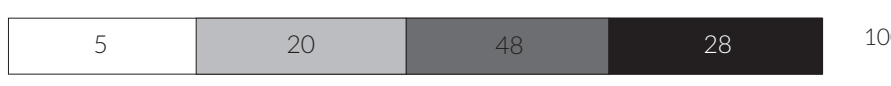

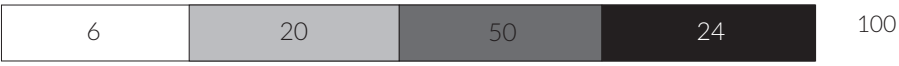

\begin{tabular}{|l|l|l|l|}
\hline 3 & 9 & 44 & 45 \\
\hline
\end{tabular}


Figure 4.1: Item map for the scale reflecting students' attitudes toward cooperation among European countries

How much do you agree or disagree with the following statements?

European countries should cooperate to protect the environment (e.g. through programs to limit pollution, programs to combat climate change).

European countries should cooperate to guarantee high levels of employment

European countries should cooperate to strengthen their economies

European countries should recognize all educational qualifications achieved in any other European country.

European countries should have a European army for peace-keeping missions

European countries should cooperate to prevent and combat terrorism

European countries should cooperate to combat illegal entry from non-European countries

European countries should cooperate to provide shelter to people escaping persecution in their countries for reasons of race, religion, or political opinions

European countries should cooperate to protect the environment (e.g. through programs to limit pollution, programs to combat climate change).

European countries should cooperate to guarantee high levels of employment

European countries should cooperate to strengthen their economies

European countries should recognize all educational qualifications achieved in any other European country.

European countries should have a European army for peace-keeping missions

European countries should cooperate to prevent and combat terrorism

European countries should cooperate to combat illegal entry from non-European countries

European countries should cooperate to provide shelter to people escaping persecution in their countries for reasons of race, religion, or political opinions
Scores

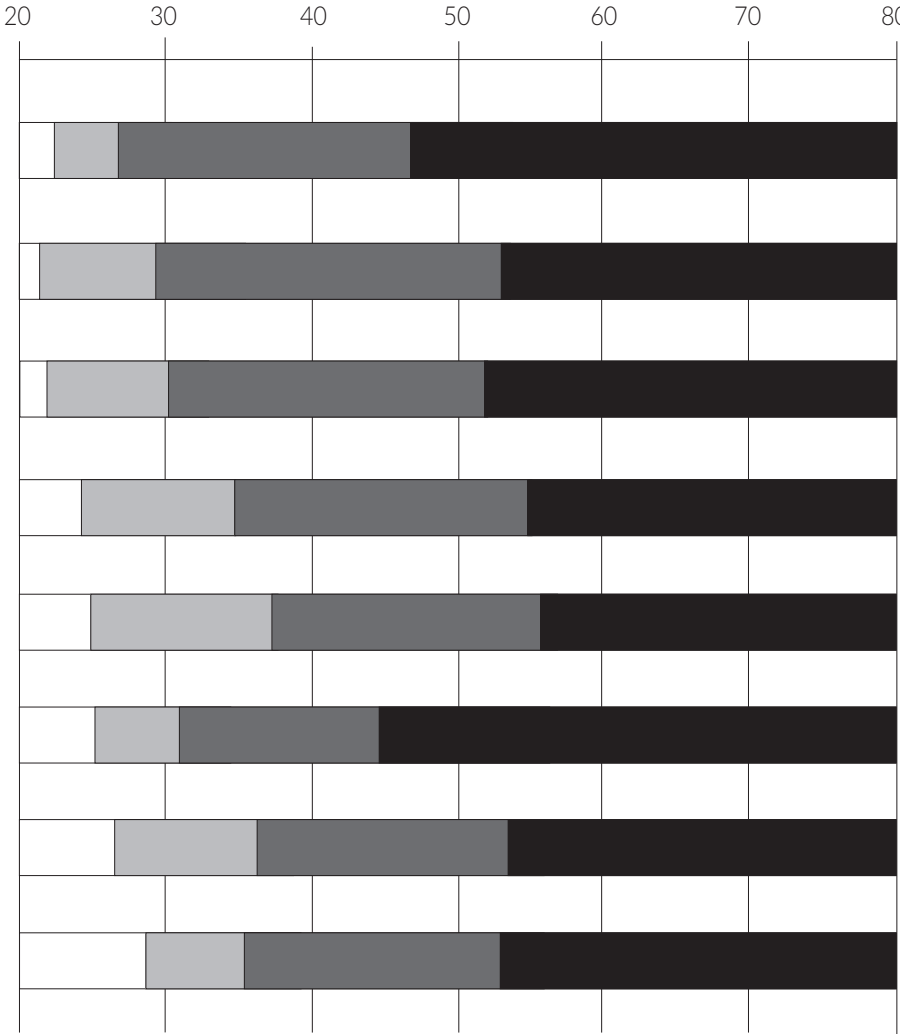

$\square$ Strongly disagree $\square$ Disagree $\square$ Agree $\quad \square$ Strongly agree

\begin{tabular}{|l|l|l|l|}
\hline 1 & 2 & 38 & 59 \\
\hline
\end{tabular}

\begin{tabular}{|l|l|l|l|}
\hline 1 & 5 & 54 & 41 \\
\hline
\end{tabular}

\begin{tabular}{|l|l|l|}
\hline 1 & 5 & 50 \\
\hline
\end{tabular}

100

\begin{tabular}{|l|l|l|l|}
\hline 1 & 10 & 53 & 36 \\
\hline
\end{tabular}

100

\begin{tabular}{|l|l|l|l|}
\hline 2 & 15 & 51 & 32 \\
\hline
\end{tabular}

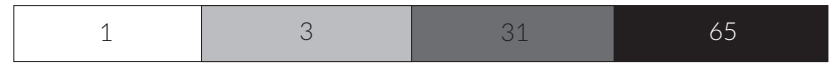

100

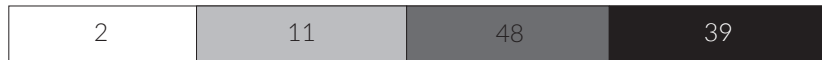

100 
Figure 4.2: Item map for the scale reflecting students' positive expectations for European future

What is Europe likely to look like in 10 years?

There will be stronger cooperation among European countries

There will be greater peace across Europe

There will be less air and water pollution in Europe

Democracy will be strengthened across Europe.

There will be stronger cooperation among European countries

There will be greater peace across Europe

There will be less air and water pollution in Europe

Democracy will be strengthened across Europe.

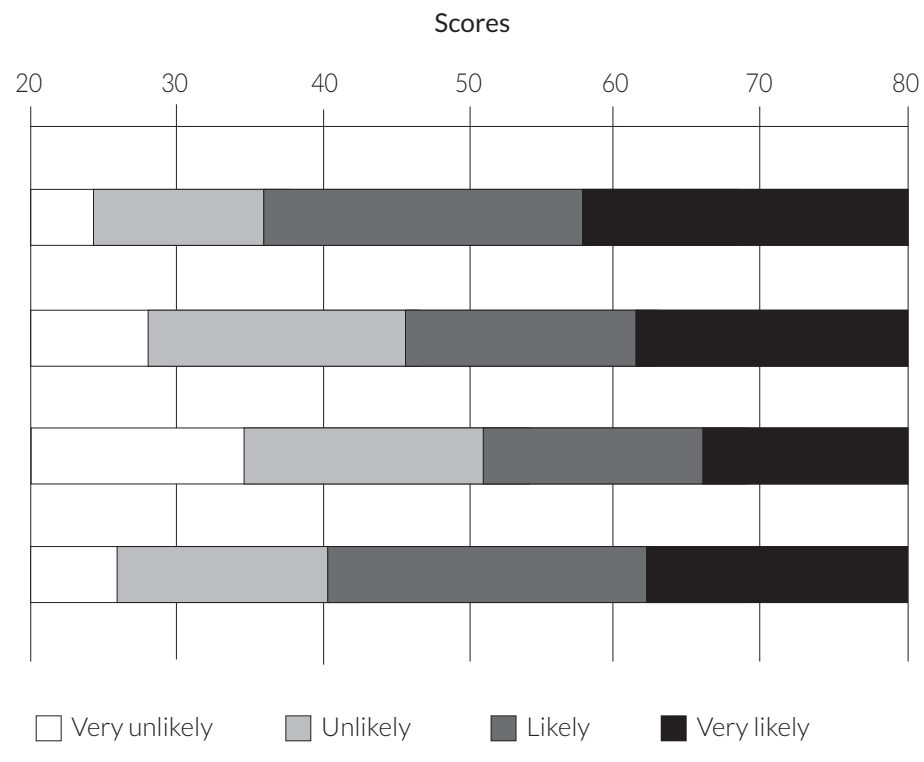

Sum

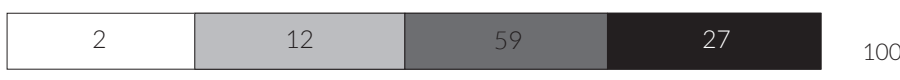

17

100

\begin{tabular}{l|l|l|}
3 & 19 & 60
\end{tabular}

\begin{tabular}{|l|l|l|l|}
\hline 11 & 42 & 37 & 10 \\
\hline
\end{tabular}

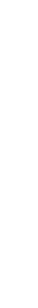

.
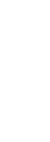

(1)


Figure 4.3: Item map for the scale reflecting students' negative expectations for European future

What is Europe likely to look like in 10 years?

Terrorism will be more of a threat all across Europe

Europe will be more influenced by non-European powers like China, India, and the United States

The economy will be weaker in all European countries

There will be a rise in poverty and unemployment in Europe

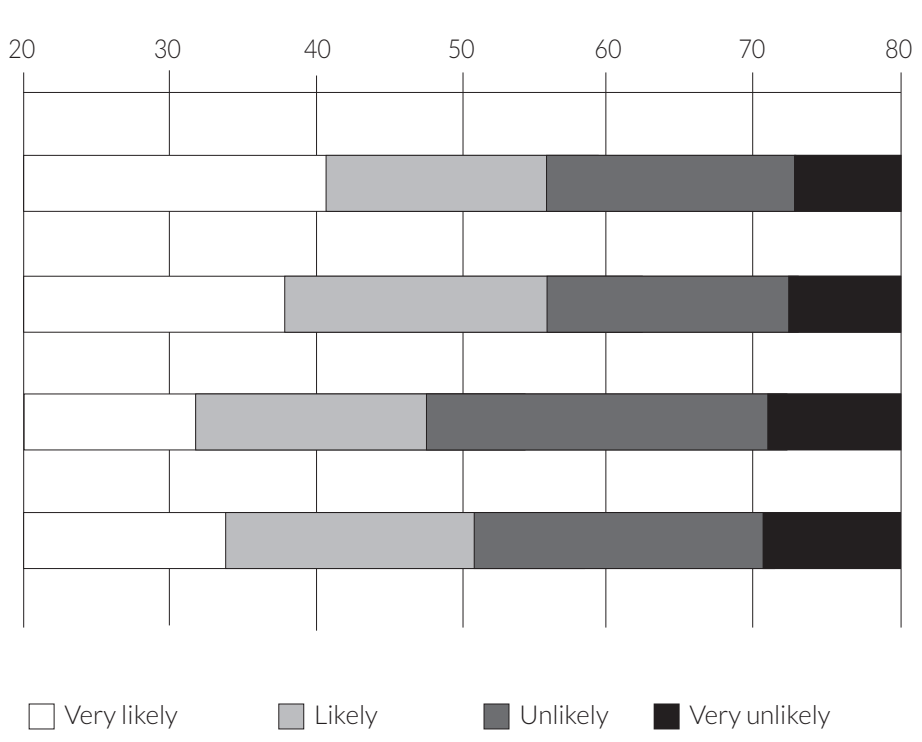

Sum

Terrorism will be more of a threat all across Europe

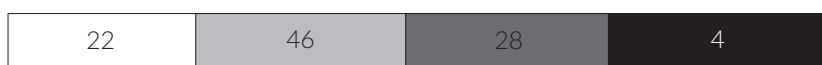

100

Europe will be more influenced by non-European powers like China, India, and the United States

\begin{tabular}{|c|c|c|c|}
\hline 18 & 50 & 28 & 4 \\
\hline 8 & 35 & 51 & 7 \\
\hline
\end{tabular}

100

The economy will be weaker in all European countries

There will be a rise in poverty and unemployment in Europe
11
80

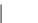


Figure 4.4: Item map for the scale reflecting students' attitudes toward European Union

How much do you agree or disagree with the following statements?

$<$ EU $>$ guarantees respect for human rights all over Europe

\section{$<$ EU $>$ makes Europe a safe place to live}

\section{$<$ EU > takes care of the environment}

$<$ EU $>$ is good for the economy of individual countries

$<$ EU $>$ is good because countries share a common set of rules and laws

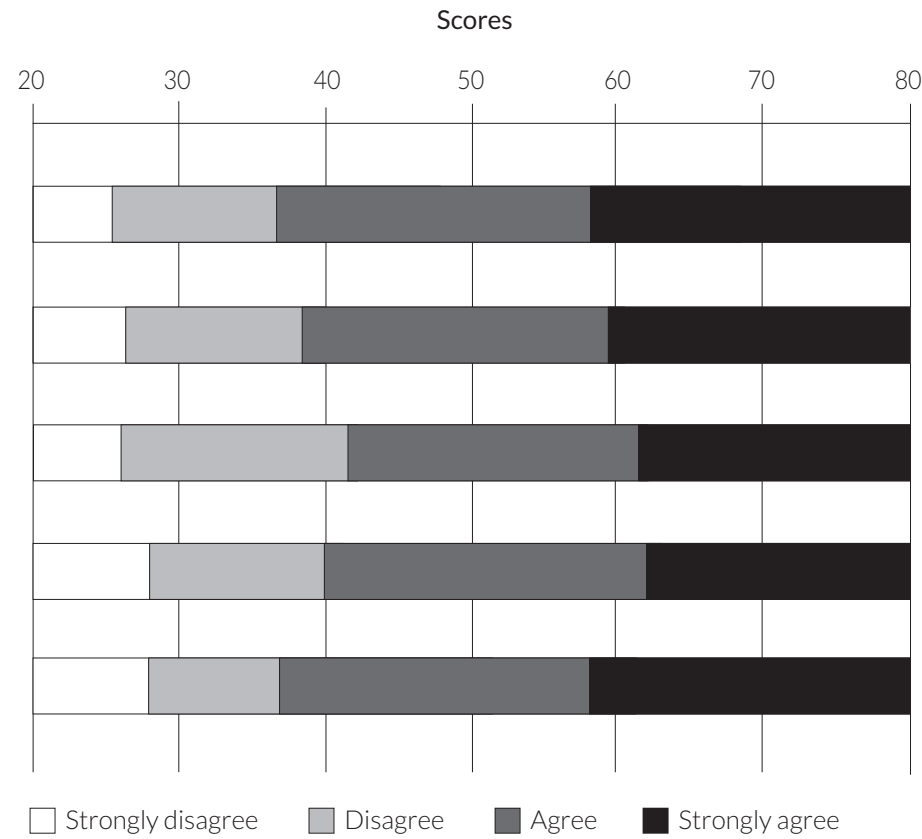

Strongly disagree

$\square$ Disagree

Agree
$<$ EU > guarantees respect for human rights all over Europe

$<$ EU $>$ makes Europe a safe place to live

$<$ EU $>$ takes care of the environment

$<$ EU $>$ is good for the economy of individual countries

$<$ EU $>$ is good because countries share a common set of rules and laws
Sum
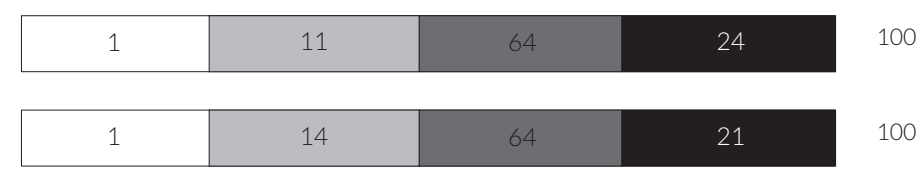

\begin{tabular}{|c|c|c|c|}
\hline 2 & 22 & 60 & 17 \\
\hline
\end{tabular}

\begin{tabular}{|l|l|l|l|}
\hline 2 & 17 & 65 & 16 \\
\hline
\end{tabular}

2 
Figure 4.5: Item map for the scale reflecting students' expectations for their individual future

How likely do you think it is that your future will look like this?

I will find a steady job

My financial situation will be better than that of my parents

I will find a job I like

I will have the opportunity to travel abroad for leisure

I will earn enough money to start a family

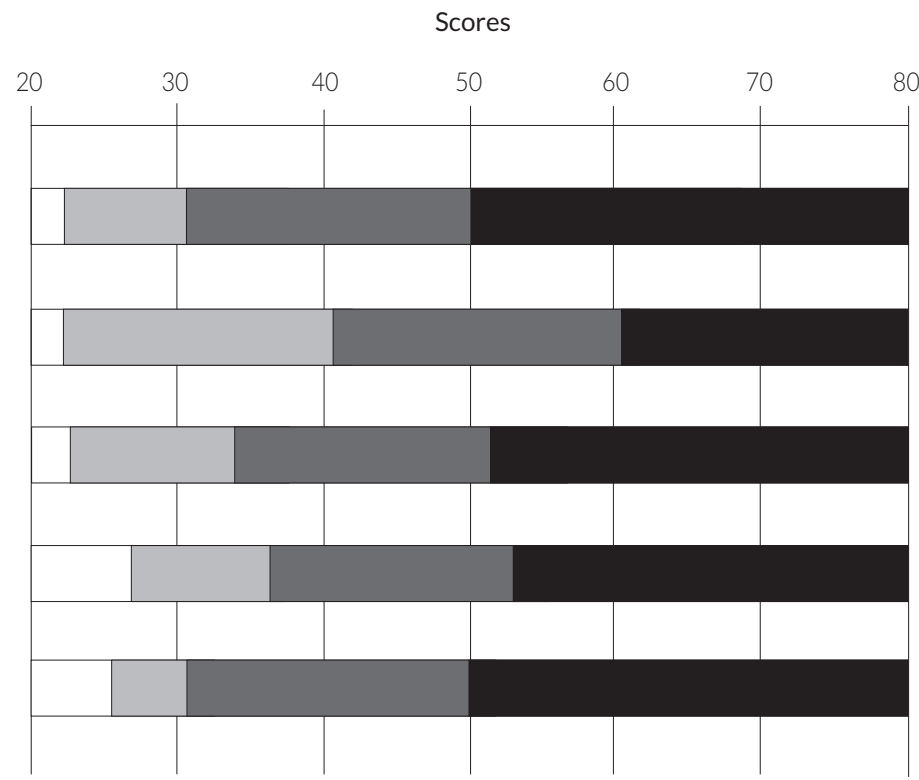

$\square$ Very unlikely $\quad \square$ Unlikely $\quad \square$ Likely $\quad \square$ Very likely

I will find a steady job

\begin{tabular}{|l|l|l|}
\hline 1 & 4 & 43 \\
\hline
\end{tabular}

100

My financial situation will be better than that of my parents

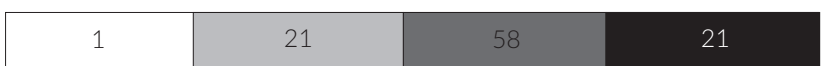

100

I will find a job | like

\begin{tabular}{|l|l|l|l|}
\hline 1 & 7 & 45 & 47 \\
\hline
\end{tabular}

100

I will have the opportunity to travel abroad for leisure

\begin{tabular}{|l|l|l|l|}
\hline 2 & 9 & 46 & 43 \\
\hline
\end{tabular}

100

I will earn enough money to start a family

\begin{tabular}{|l|l|l|}
\hline 1 & 3 & 43
\end{tabular}

100 


\section{References}

Masters, G. N., \& Wright, B. D. (1997). The partial credit model. In W. J. van der Linden \& R. K. Hambleton (Eds.), Handbook of modern item response theory (pp. 100-222). New York, NY: Springer

Schulz, W., Carstens, R., Losito, B., \& Fraillon, J. (Eds.) (forthcoming). ICCS 2016 technical report. Amsterdam, the Netherlands: International Association for the Evaluation of Educational Achievement (IEA).

Schulz, W., \& Friedman, T. (2011). Scaling procedures for ICCS questionnaire items. In W. Schulz, J. Ainley, \& J. Fraillon (Eds.), ICCS 2009 technical report (pp. 157-259). Amsterdam, the Netherlands: International Association for the Evaluation of Educational Achievement (IEA).

Warm, T. A. (1989). Weighted likelihood estimation of ability in item response theory. Psychometrika, 54(3), 427-520. 


\section{APPENDIX D: ORGANIZATIONS AND INDIVIDUALS INVOLVED IN ICCS 2016}

International Study Center

The international study center is located at the Australian Council for Educational Research (ACER). ACER is responsible for designing and implementing the study in close cooperation with LPS (Laboratorio di Pedagogia Sperimentale at the Roma Tre University, Rome, Italy) on behalf of the IEA.

\section{Staff at ACER}

Wolfram Schulz, research director Julian Fraillon, coordinator of test development John Ainley, project researcher

Tim Friedman, project researcher

Nora Kovarcikova, project researcher

Naoko Tabata, project researcher

Judy Nixon, test development

Trisha Reimers, test development

Eveline Gebhardt, coordinator of data analysis

Louise Ockwell, data analyst

Jorge Fallas, data analyst

Leigh Patterson, data analyst

Dulce Lay, data analyst

Renee Kwong, data analyst

\section{Staff at LPS}

Bruno Losito, associate research director

Gabriella Agrusti, project researcher

Valeria Damiani, project researcher

Elisa Caponera, project researcher

Paola Mirti, project researcher

Francesco Agrusti, project researcher

Alessandro Sanzo, project researcher

\section{International Association for the Evaluation of Educational Achievement (IEA)}

IEA provides overall support and supervision for ICCS. The IEA Hamburg, Germany, as the international coordinating center for ICCS, is responsible for overall coordination of all activities, relations with participating countries, and sampling and data-processing. The IEAAmsterdam, the Netherlands, is responsible for translation verification and quality monitoring of the data collection.

\section{Staff at the IEA Hamburg}

Ralph Carstens, project director Marta Kostek, project coordinator Juliane Kobelt, project coordinator Falk Brese, international data manager Hannah Köhler, international data manager Christine Busch, deputy international data manager Sabine Weber, researcher (sampling) Sabine Tieck, researcher (sampling) Diego Cortes, researcher (sampling) Olaf Zuehlke, researcher (sampling) Duygu Savasci, research analyst (sampling) 
Dirk Oehler, research analyst

Tim Daniel, research analyst

Michael Jung, research analyst

Alena Becker, research analyst

Parisa Aghakasiri, research analyst

Kamil Kowolik, research analyst

Svetoslav Velkov, research analyst

Ekaterina Mikheeva, research analyst

Clara Beyer, research analyst

Oriana Mora, research analyst

Maike Junod, programmer

Limiao Duan, programmer

Deepti Kalamadi, programmer

Bettina Wietzorek, meeting and seminar coordinator

Heiko Sibberns, director

\section{Staff at the IEA Amsterdam}

Dirk Hastedt, executive director

Paulína Koršñáková, director of the IEA Secretariat

Andrea Netten, director of the IEA Secretariat

Gabriela Noveanu, senior researcher

Gillian Wilson, publications officer

Roel Burgers, financial manager

Isabelle Gemin, financial officer

Anna Kähne, public outreach officer

\section{Project advisory committee (PAC)}

The ICCS 2016 PAC has, from the beginning of the project, advised the international study center and its partner institutions during regular meetings.

\section{PAC members}

Erik Amnå, Örebro University, Sweden

Cristián Cox, Diego Portales University, Chile

Barbara Malak-Minkiewicz, Netherlands

Judith Torney-Purta, University of Maryland, United States

Wiel Veugelers, University of Humanistic Studies Utrecht, Netherlands

\section{Other project advisors \\ ICCS sampling referee}

Marc Joncas from Statistics Canada in Ottawa was the sampling referee for the study. He provided invaluable advice on all sampling-related aspects of the study.

\section{Experts}

Christian Monseur (University of Liege) conducted a review of test and questionnaires scaling methodology.

Barbara Malak-Minkiewicz was invited by the international study center to review the European report's content. 


\section{ICCS 2016 national research coordinators (NRCs)}

The national research coordinators (NRCs) played a crucial role in the study's development. They provided policy-and content-oriented advice on developing the instruments and were responsible for the implementation of ICCS 2016 in the participating countries.

\section{Belgium (Flemish)}

Ellen Claes

University of Leuven, Centre for Citizenship and Democracy

\section{Bulgaria}

Svetla Petrova

Center for Control and Assessment of the Quality in School Education

\section{Croatia}

Ines Elezović

Department for Quality Assurance in Education, National Centre for External Evaluation of Education

\section{Denmark}

Jens Bruun

Danish School of Education, Aarhus University

\section{Estonia}

Anu Toots

Tallin University

\section{Finland}

Jouko Mehtäläinen

Finnish Institute for Educational Research, University of Jyväskylä

\section{Germany (North Rhine-Westphalia)}

Hermann Josef Abs

University of Duisburg-Essen

\section{Italy}

Laura Palmerio

INVALSI

\section{Latvia}

Ireta Chekse

University of Latvia

\section{Lithuania}

Mindaugas Stundža

Justė Grebliūnienè

National Examination Center

\section{Malta}

Karen Grixti

Directorate for Research and Policy Development

\section{The Netherlands}

Anke Munniksma

University of Amsterdam

\section{Norway}

Lihong Huang

NOVA-Norwegian Social Research, Oslo and Akershus University College of Applied Sciences 
Slovenia

Eva Klemencic

Educational Research Institute

\section{Sweden}

Ellen Almgren

Swedish National Agency for Education 